DOE/NASA/0282-1

NASA CR-185174

\title{
Identification of a Cast Iron Alloy Containing Nonstrategic Elements
}

Final Report

C.V. Cooper, D.L. Anton, F.D. Lemkey, H. Nowotny, R.S. Bailey, L.H. Favrow, J.G. Smeggil, and D.B. Snow United Technologies Research Center

June 1989

Prepared for

NATIONAL AERONAUTICS AND SPACE ADMINISTRATION Lewis Research Center

Under Contract DEN3-282

for

U.S. DEPARTMENT OF ENERGY

Conservation and Renewable Energy

Office of Vehicle and Engine R\&D

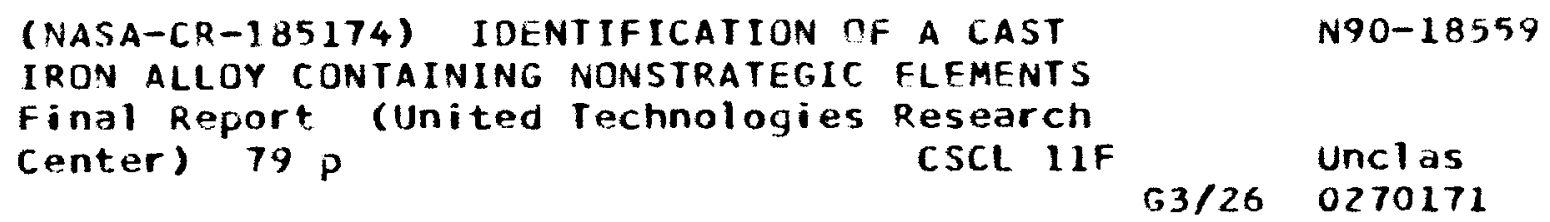




\section{DISCLAIMER}

This report was prepared as an account of work sponsored by an agency of the United States Government. Neither the United States Government nor any agency thereof, nor any of their employees, makes any warranty, express or implied, or assumes any legal liability or responsibility for the accuracy, completeness, or usefulness of any information, apparatus, product, or process disclosed, or represents that its use would not infringe privately owned rights. Reference herein to any specific commercial product, process, or service by trade name, trademark, manufacturer, or otherwise, does not necessarily constitute or imply its endorsement, recommendation, or favoring by the United States Government or any agency thereof. The views and opinions of authors expressed herein do not necessarily state or reflect those of the United States Government or any agency thereof.

Printed in the United States of America

Available from

National Technical Information Service

U.S. Department of Commerce

5285 Port Royal Road

Springfield, VA 22161

NTIS price codes 1

Printed copy: A05

Microfiche copy: A01

${ }^{1}$ Codes are used for pricing all publications. The code is determined by the number of pages in the publication. Information pertaining to the pricing codes can be found in the current issues of the following publications, which are generally available in most libraries: Energy Research Abstracts (ERA); Government Reports Announcements and Index (GRA and 1); Scientific and Technical Abstract Reports (STAR); and publication, NTIS-PR-360 available from NTIS at the above address. 
DOE/NASA/0282-1

NASA CR-185174

R89-917447-32

\section{Identification of a Cast Iron Alloy Containing Nonstrategic Elements}

\section{Final Report}

C.V. Cooper, D.L. Anton, F.D. Lemkey, H. Nowotny, R.S. Bailey, L.H. Favrow, J.G. Smeggil, and D.B. Snow

United Technologies Research Center

East Hartford, Connecticut 06108

June 1989

Prepared for

National Aeronautics and Space Administration

Lewis Research Center

Cleveland, Ohio 44135

Under Contract DEN3-282

for

U.S. DEPARTMENT OF ENERGY

Conservation and Renewable Energy

Office of Vehicle and Engine R\&D

Washington, D.C. 20545

Under Interagency Agreement DE-Al01-77CS51040 


\section{CONTENTS}

1.0 EXECUTIVE SUMMARY $\ldots \ldots \ldots \ldots \ldots \ldots \ldots \ldots \ldots \ldots \ldots \ldots \ldots \ldots \ldots \ldots$

2.0 INTRODUCTION $\ldots \ldots \ldots \ldots \ldots \ldots \ldots \ldots \ldots \ldots \ldots \ldots \ldots \ldots \ldots \ldots \ldots \ldots$

3.0 RESULTS AND DISCUSSION $\ldots \ldots \ldots \ldots \ldots \ldots \ldots \ldots \ldots \ldots \ldots \ldots \ldots \ldots \ldots$

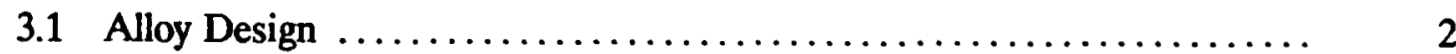

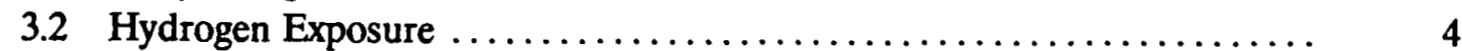

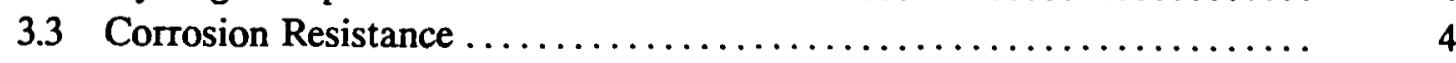

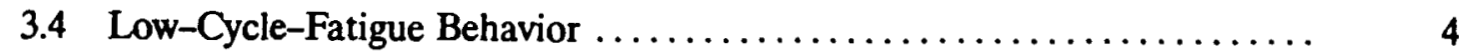

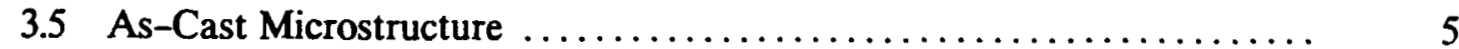

3.6 Heat-Treatment Optimization and Microstructure ............... 5

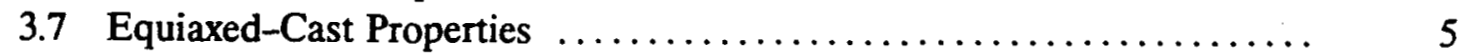

3.8 Carbon Modification ................................... 7

3.9 Properties of Transversely Oriented, Directionally Solidified

3.10 Properties of Longitudinally Oriented, Directionally Solidified

(Columnar Grain) Castings in the SBC Condition ............... 9

4.0 SUMMARIZING REMARKS AND CONCLUSIONS ............... 10

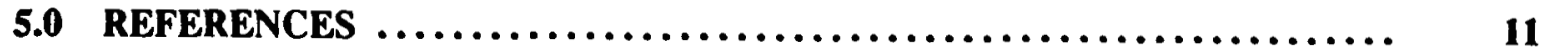




\subsection{EXECUTIVE SUMMARY}

A program has been carried out to address the mechanical and environmental needs of Stirling engine heater head and regenerator housing components, while reducing the dependence on strategic materials. Current candidate materials for such applications contain significant levels of cobalt, nickel, chromium, and/or tantalum. An alloy was developed during this program which contained none of these strategic elemental additions per se. The base is iron with additions of manganese, molybdenum, carbon, silicon, niobium, and ferro-chromium. Such an alloy should be producible on a large scale at very low cost.

The resulting alloy, designated as NASAUT 4G-A1, contained $15 \mathrm{Mn}, 15 \mathrm{Cr}, 2 \mathrm{Mo}, 1.5 \mathrm{C}, 1.0 \mathrm{Si}$, $1.0 \mathrm{Nb}$ (in weight percent) with a balance of Fe. This alloy (and several others along the development path) was optimized for chemistry, based upon tensile strength, creep-rupture strength, fracture behavior, and fatigue resistance up to $800^{\circ} \mathrm{C}$. Alloys were also tested for environmental compatibility (in air, salt fog, and hydrogen). The microstructure and mechanical properties (including hardness) were assessed in the as-cast condition and following several heat treatments, including one designed to simulate a required braze cycle. The alloy was fabricated and characterized in the form of both equiaxed and columnar-grained castings. The columnar grains were produced by directional solidification, and the properties were characterized in both the longitudinal and transverse orientations.

The NASAUT 4G-A1 alloy was found to be good in cyclic-oxidation resistance and excellent in both hydrogen and hot-corrosion resistance, especially in comparison to the baseline XF-818 alloy. The mechanical properties of yield strength, stress-rupture life, high-cycle-fatigue resistance, and low-cycle-fatigue resistance were good to excellent in comparison to the current alloy for this application, HS-31 (X-40), with precise results depending in a complex manner on grain orientation and temperature. If required, the ductility could be improved by lowering the carbon content.

In summary, a castable, low-cost, iron-based superalloy has been demonstrated with excellent stress-rupture properties and environmental resistance in oxygen and hydrogen to $800^{\circ} \mathrm{C}$. This alloy may be appropriate for automotive Stirling engine as well as other applications requiring low-cost, heat-resisting alloys.

\subsection{INTRODUCTION}

A need exists for a low-cost, cast, iron-based alloy which can be used for improved automotive Stirling engine cylinder and regenerator housing components. This alloy must meet the requirements of high strength and thermal-fatigue resistance to $800^{\circ} \mathrm{C}$, must be compatible with and have low permeability to hydrogen, must possess elevated temperature oxidation/corrosion resistance, and must contain a minimum of strategic elements. Alloys in prototype automotive Stirling engines under Department of Energy (DOE) development programs (Ref. 1) have not met all of these criteria, particularly with regard to alloy cost and availability. The purpose of this program has been to address the development of a cast, iron-based alloy, utilizing alloying additions such as manganese, aluminum, carbon, and nitrogen, such that a shift away from additions such as cobalt and nickel is rendered 
possible. Because of the higher carbon levels of the alloys developed as part of this program ( $>1.0 \mathrm{wt}$ $\%$ ), ferro-chromium, derived from chromite deposits found in the western United States, has become a viable source for chromium additions. Until recently, these chromite deposits had been considered too low grade for stainless steel manufacturers because of the lower chromium-to-iron ratio of 1.5:1 and their higher carbon content (Ref. 2).

This program has consisted of an initial alloy-composition iteration and properties determination phase, in which results of cyclic-oxidation, tensile, and stress-rupture tests were used to screen alloys. The base alloy composition originated from the austenitic matrix of a directionally solidified (DS) eutectic composite which was originally developed for aircraft gas turbine use (Ref. 3). Following the determination of an initial alloy composition, based on a balance of physical and mechanical properties, extensive studies were focused on the variation of tensile fatigue properties with temperature. Investment-cast test bars were produced and given various heat treatments to optimize properties and to simulate possible brazing cycles. In addition, extensive microstructural investigations were conducted to characterize the as-cast and heat-treated microstructures.

Another objective of this study was to determine the possibility of increasing the ductility and improving the high- and low-cycle-fatigue properties of the alloy without sacrificing strength by modifications in the carbon content. This was followed by a study to determine the degree of anisotropy in the directionally solidified (DS) castings by examining the mechanical properties of simulated-braze-cycled (SBC), longitudinally and transversely oriented specimens.

This study has produced a high-carbon, castable, iron-based superalloy with excellent stress-rupture and oxidation properties. The final alloy, designated NASAUT 4G-A1, has been shown to remain virtually unaffected by high temperature hydrogen exposure at standard pressure. The maximum temperature for use of this alloy is $800^{\circ} \mathrm{C}\left(1472^{\circ} \mathrm{F}\right)$, far in excess of conventional stainless steels. Most importantly, this alloy has been found to have a raw-materials cost of $\$ 0.37 / \mathrm{kg}$ (\$0.81/lb) (Refs. 4 and 5) by containing nonstrategic materials, only.

\subsection{RESULTS AND DISCUSSION}

\subsection{Alloy Design}

The initial eutectic-alloy composition of $10 \mathrm{Cr}, 20 \mathrm{Mn}, 3.3 \mathrm{C}$, bal $\mathrm{Fe}$ (all compositions given in wt $\%$ unless otherwise specified) (Ref. 3) was modified by removing carbon in order to obtain a castable, austenitic alloy. Thus, the original alloy composition, designated as NASAUT 1, contained $10 \mathrm{Cr}, 20$ $\mathrm{Mn}, 1.5 \mathrm{C}$, bal Fe. The iteration flow chart used for alloy modifications to enhance stress-rupture and oxidation resistance is given in Fig. 1.

The first alloy iteration included modifying the $\mathrm{Cr}$ and $\mathrm{Mn}$ compositions to $15 \pm 5$, Mo to 10 , $\mathrm{C}$ at 1.0 and 1.5 , and $\mathrm{Al}$ to 2 . These alloys were obtained by induction melting commercial purity starting elements and pouring into $\mathrm{Cu}$-molded chill bars. Subsequent vacuum re-melting and solidification through a $200^{\circ} \mathrm{C} / \mathrm{cm}$ thermal gradient at $10 \mathrm{~cm} / \mathrm{h}$ were used to eliminate shrinkage pipe and produce sound test specimens. 
A major emphasis of this program was the $\mathrm{x}$-ray identification of phases within the alloys as a function of constituent concentration. The degree of matrix stability as well as the carbide types and volume fractions were monitored. The base alloy, NASAUT 1, maintained an austenitic, FCC matrix which contained 12 vol \% carbides, primarily of the $\mathrm{M}_{7} \mathrm{C}_{3}$-type.

Tensile tests were carried out at ambient temperature and $788^{\circ} \mathrm{C}\left(1450^{\circ} \mathrm{F}\right)$ in air at a strain rate of $0.01 \mathrm{~min}^{-1}$. To summarize the initial program results, an increase in the carbon content was found to increase the strength significantly and decrease the ductility of the alloys; minor Mo additions were found to be beneficial to strength.

Two alloys were clearly superior in stress-rupture performance at $776^{\circ} \mathrm{C}$ at stresses between 170 and $240 \mathrm{MPa}$ in air. The base alloy and that designated NASAUT 4, having the composition $15 \mathrm{Mn}, 12$ $\mathrm{Cr}, 3 \mathrm{Mo}, 1.5 \mathrm{C}$, and bal $\mathrm{Fe}$, maintained superior stress-rupture lives compared to the other candidate alloys.

Cyclic-oxidation tests were conducted by heating round, penny-shaped specimens in air to $871^{\circ} \mathrm{C}$ for $55 \mathrm{~min}$ and withdrawing to ambient temperature for $5 \mathrm{~min}$. Based on mass changes per unit surface area, NASAUT alloys $\# 1, \# 3$, and $\# 4$ maintained the greatest resistance to surface attack. Aluminum additions were found to increase the surface stability and elevated-temperature ductility of these alloys greatly; however, these additions were found to be quite deleterious to the stress-rupture and tensile strength.

From the above results, NASAUT alloys \#1 and \#4 were promoted to the second alloying iteration based on the combination of improved tensile strengths, superior rupture lives, and good oxidation resistance.

A second alloy iteration was performed on the above two mentioned compositions. In this case, $\mathrm{Al}$ was varied from 0 to $5, \mathrm{Si}$ from 0 to $1.5, \mathrm{Nb}$ from 0 to 1.0, and Mo from 0 to 3.0. Screening again on stress-rupture and tensile strength, two alloys, $1 \mathrm{G}$ and $4 \mathrm{G}$, were observed to have superior attributes. Alloy $4 \mathrm{G}$ was found to have greater room-temperature tensile strength than $1 \mathrm{G}$, while their elevated temperature properties were similar. The compositions were $10 \mathrm{Mn}, 20 \mathrm{Cr}, 1.5 \mathrm{C}, 1.0 \mathrm{Si}$, and bal Fe and $15 \mathrm{Mn}, 12 \mathrm{Cr}, 3 \mathrm{Mo}, 1.5 \mathrm{C}, 1.0 \mathrm{Si}, 1.0 \mathrm{Nb}$, and bal Fe for alloys $1 \mathrm{G}$ and $4 \mathrm{G}$, respectively. Aluminum additions were discontinued due to the deleterious effects on stress-rupture properties. Silicon was found to have the same beneficial effects in terms of cyclic-oxidation resistance; therefore, it has become an important alloy constituent. The niobium was found to precipitate the primary $\mathrm{NbC}$, which helped to strengthen the $4 \mathrm{G}$ alloy; furthermore, its role in promoting improved sulfidation resistance was found to be critical. On the basis of its superior ambient-temperature strength, NASAUT 4G was selected for further alloy modification.

In the third alloy iteration, the following modifications were made to $4 \mathrm{G}: \mathrm{Cr} \pm 3, \mathrm{Mo}-1, \mathrm{Nb}-0.5$, $\mathrm{Si}+2$, and $\mathrm{B}+0.1$. Chromium was added to increase rupture life, silicon was added to enhance oxidation resistance, and boron was added to precipitate the $\mathbf{M}_{3} \mathbf{B}_{2}$ phase and enhance strength.

Stress-rupture testing was conducted on specimens aged at $650^{\circ} \mathrm{C}$ for $100 \mathrm{~h}$ to simulate operating exposure. The boron additions resulted in a small debit to rupture life and was, therefore, 
discontinued. Chromium additions enhanced stress-rupture behavior, while reductions in the refractory metals were deleterious to the rupture life. Further additions of silicon $(>1 \%)$ failed to enhance the oxidation resistance of the alloy and were deemed unnecessary. This led to the selection of alloy $4 \mathrm{G}-\mathrm{A}$, containing $15 \mathrm{Mn}, 15 \mathrm{Cr}, 2 \mathrm{Mo}, 1.5 \mathrm{C}, 1.0 \mathrm{Si}, 1.5 \mathrm{Nb}$, and bal Fe.

The final alloy iteration included rare-earth additions to the alloy and a further attempt to reduce the refractory content. Only the addition of 0.5 yttrium was found to be beneficial to cyclic-oxidation resistance, while the other rare-earth elements produced no significant effect other than a slight debit to oxidation resistance. A slight reduction in the niobium content to 1.0 was found to have little effect on rupture life and was found to promote cyclic-sulfidation resistance (Ref. 6). The contribution from yttrium was deemed insufficient to include it as an alloy constituent. Thus, the final alloy chemistry devised here was given the designation NASAUT 4G-A1 and contained $15 \mathrm{Mn}, 15 \mathrm{Cr}, 2 \mathrm{Mo}, 1.5 \mathrm{C}, 1.0$ $\mathrm{Si}, 1.0 \mathrm{Nb}$, and bal $\mathrm{Fe}$. In this alloying scheme, NASAUT 4G-A1 was determined to have the best combination of tensile and stress-rupture strength and cyclic-oxidation and -sulfidation stability. The stress-rupture data for this alloy are given in Fig. 2, where several other candidate alloys for Stirling engine heater head assemblies are compared to the final alloy iteration of this study. The cyclic-oxidation results for NASAUT $4 \mathrm{G}-\mathrm{A} 1$, a number of $4 \mathrm{G}$-alloy modifications, and the alloys HS-31 and XF-818 are shown in Fig. 3.

\subsection{Hydrogen Exposure}

To determine the stability of this alloy to hydrogen, a specimen was creep tested in $101 \mathrm{kPa}(1 \mathrm{~atm})$ of dynamic $\mathrm{H}_{2}$ at $900^{\circ} \mathrm{C}$ after an initial heat treatment of $650^{\circ} \mathrm{C} / 100 \mathrm{~h}$ in air. No significant loss in rupture life was observed from the tests conducted in flowing hydrogen. In addition, no $\mathrm{H}_{2}$ pick-up was evident upon microstructural or chemical analyses. The carbide network showed no signs of reduction, even at the specimen surface, illustrating its resistance to hydrogen attack at temperatures less than or equal to $900^{\circ} \mathrm{C}$.

\subsection{Corrosion Resistance}

As discussed above, a test of the corrosion resistance of HS-31, XF-818, and NASAUT 4G-A1 was made by exposing these alloys at $871^{\circ} \mathrm{C}$ to $35 \mathrm{ppm} \mathrm{NaCl}$ aspirated in air, typical of the environment adjacent to the ocean or on a street spread with salt to remove ice. The results were quite dramatic, as shown in Fig. 4. It is clear that both HS-31 and NASAUT 4G-A1 were resistant to salt corrosion, while the XF-818 coupon was completely consumed.

\subsection{Low-Cycle-Fatigue Behavior}

Constant-strain-amplitude, low-cycle-fatigue tests were conducted at $800^{\circ} \mathrm{C}$ in air on specimens produced as described previously. Throughout this program, low-cycle-fatigue tests were conducted in laboratory air under total-strain control. A constant total strain rate of $0.005 \mathrm{sec}^{-1}$ was maintained through the application of a completely reversed $\left(R^{\prime}=-1\right)$, triangular waveform. The results of these tests are given in Fig. 5, where comparison is made to HS-31, a cobalt-based alloy used in experimental automotive Stirling engine designs because of its resistance to hydrogen attack. The 
results indicate that NASAUT 4G-A1 is a factor of 5 to 10 superior to HS-31 in terms of LCF performance. This is especially apparent at low strain amplitudes, where run-out was experienced at a significantly higher strain amplitude for alloy $4 \mathrm{G}-\mathrm{A} 1$.

Subsequent analysis of the fatigue data indicated that the measured modulus for the specimens was significantly lower than that expected for polycrystalline austenitic iron. The lower modulus is believed to have resulted from the DS process utilized. This process achieved essentially a pore-free alloy (neglecting microporosity) with a columnar, dendritic structure, having predominantly a [001] texture aligned with the growth axis. Subsequent screening-type mechanical tests were carried out on finer-sized, equiaxed-grain castings.

\subsection{As-Cast Microstructure}

A typical optical micrograph of alloy NASAUT $4 \mathrm{G}-\mathrm{A} 1$ after LCF testing for 12 hours at $800^{\circ} \mathrm{C}$ is given in Fig. 6. Here feature " $\mathrm{A}$ " has been identified as the primary $\mathrm{NbC}$, feature " $\mathrm{B}$ " as the $\mathrm{Cr}-\mathrm{rich}$ $\mathrm{Cr}_{7} \mathrm{C}_{3}$, and feature " $\mathrm{C}$ " as a two-phase precipitate with " $\mathrm{a}$ " being a manganese-sulfide inclusion and " $b$ " being a manganese-aluminum-sulfide inclusion. The latter exhibits quite an innocuous form and is considered to be an excellent means of desulfurizing the alloy. Both of the carbides are considered to help in strengthening the alloy.

\subsection{Heat-Treatment Optimization and Microstructure}

The age-hardening response of this alloy has been investigated in an attempt to optimize the heat treatment. An isothermal aging curve is given in Fig. 7. Classical aging is demonstrated, with continuous hardening being displayed through $100 \mathrm{~h}$ at temperatures below $760^{\circ} \mathrm{C}$; however, hardening followed by softening is exhibited at higher temperatures. This behavior is indicative of the coarsening of fine precipitates.

To verify the hardening response, a TEM investigation was conducted on specimens aged at $870^{\circ} \mathrm{C} / 8 \mathrm{~h}$, an under age, and $980^{\circ} \mathrm{C} / 32 \mathrm{~h}$, an over age. Representative microstructures for these two heat treatments are presented in Figs. 8 and 9. The small, cuboidal plates are $\mathbf{M}_{23} \mathrm{C}_{6}$ precipitates, which were identified previously via $x$-ray analysis; the grid pattern of faults was identified as stacking faults forming on (111) planes. Faults exhibiting similar morphology have been reported to be precursors to $\mathrm{M}_{23} \mathrm{C}_{6}$ precipitates (Ref. 7). This is consistent with the plate-like morphology of the $\mathrm{M}_{23} \mathrm{C}_{6}$ precipitates shown in Fig. 8. As displayed in Fig. 9, overaging has minimized the occurrence of faults, leaving behind the coarse $\mathrm{M}_{23} \mathrm{C}_{6}$.

\subsection{Equiaxed-Cast Properties}

Since the tensile and low-cycle-fatigue properties were observed to depend acutely on the modulus of the material, equiaxed-cast bars were prepared and specimens machined in order to duplicate the LCF results reported above. Shell-mold castings of NASAUT 4G-A1 were produced by Garrett AiResearch Co. Metallographic examination revealed the microstructure to consist of equiaxed grains having interdendritic spacings of between 20 and $40 \mu \mathrm{m}$ (Fig. 18). 
3.7.1 Heat-Treatment Optimization. In addition to the as-cast properties, three heat treatments were devised to study the influence of heat treatment on properties. As partially described above, these heat treatments were: (a) $760^{\circ} \mathrm{C} / 8 \mathrm{~h}$, designated as "under aged," (b) $760^{\circ} \mathrm{C} / 20 \mathrm{~h}+$ $870^{\circ} \mathrm{C} / 10 \mathrm{~h}$, designated as "super aged," which produced the highest $\mathrm{R}_{\mathrm{c}}$ hardness measured in this alloy, and (c) $1065 \mathrm{C} / 30 \mathrm{~min}+790^{\circ} \mathrm{C} / 16 \mathrm{~h}+650^{\circ} \mathrm{C} / 16 \mathrm{~h}$, designated as the "simulated-braze cycle" (SBC), which is a variation on the Mod II standard braze cycle which MTI uses during the manufacture of automotive Stirling engine heater heads (Ref. 8).

3.7.2 Tensile Properties. The results of the tensile tests on these four heat-treated alloys are given graphically in Fig. 10 and 11 and tabularly in Table I, where yield strength and strain-to-failure are plotted as a function of temperature through $900^{\circ} \mathrm{C}$. The super-aged alloy maintains superior strength through $600^{\circ} \mathrm{C}$ compared to the other heat-treated specimens. Above this temperature, all of the alloys converge to approximately the same strength. The strain-to-failure is inversely related to the strength of the alloy, with the as-cast heat treatment maintaining approximately $4 \%$ strain-to-failure and the other specimens failing after 1 to $2 \%$ strain. Above $600^{\circ} \mathrm{C}$, the strain-to-failure of all alloys increases dramatically. These data, when compared to those of alloy XF-818 in Fig. 12, show the superior low- and intermediate-temperature strength of equiaxed alloy NASAUT 4G-A1. At elevated temperatures, the strength of the two alloys is comparable, while the ductility of $4 \mathrm{G}-\mathrm{A} 1$ is superior at all temperatures.

3.7.3 Low-Cycle-Fatigue Behavior. Low-cycle-fatigue tests were conducted on the equiaxed specimens in the as-cast condition in a fashion similar to that described previously. These results are given graphically in Fig. 13 along with the DS data and XF-818 data presented in Fig. 5; the data are presented tabularly in Tables II and III. The equiaxed-grain material produced substantially reduced fatigue lives compared to the original DS form but maintained a slight advantage over the XF-818 alloy.

3.7.4 Low-Cycle-Fatigue Behavior for Simulated-Braze-Cycled (SBC) Condition. The braze processing used to integrate certain automotive Stirling engine heater head components rendered the determination of the LCF properties in the simulated-braze-cycled (SBC) condition increasingly important. A comparison of the LCF behavior at $800^{\circ} \mathrm{C}$ for the SBC and as-cast conditions is given in Figs. 14 and 15 ( $c f$. Tables II and III). As shown, the simulated-braze cycle proved to be detrimental at the lower strain amplitudes at $800^{\circ} \mathrm{C}$, only. At a constant strain amplitude of $\pm 0.4 \%$, the SBC treatment resulted in inferior lives when compared to the as-cast condition at temperatures below $600^{\circ} \mathrm{C}$. Further subsequent characterization of the LCF behavior in the SBC condition at temperatures of $22^{\circ} \mathrm{C}$ and $800^{\circ} \mathrm{C}$ has been presented in Fig. 16.

3.7.5 High-Cycle-Fatigue Behavior. High-cycle-fatigue tests were conducted on SBC, equiaxed-cast specimens at a temperature of $800^{\circ} \mathrm{C}$. For this, a sinusoidal waveform at a frequency of $20 \mathrm{~Hz}$ was employed at an R-ratio of 0.1 . The results from these tests have been summarized graphically in Fig. 16 and tabularly in Table IV. These results have been produced to satisfy the concern that, in addition to low-cycle fatigue, high-cycle fatigue has been an active failure mode within the heater head and other components of the automotive Stirling engine. These results are to be compared to the HCF performance of the transversely and longitudinally oriented DS material in the SBC condition, as described below. 


\subsection{Carbon Modification}

A final alloy iteration was performed to determine the possibility of increasing the strain-to-failure of the alloy without sacrificing strength. To do this, three additional alloys were prepared in equiaxed form, having chemistries identical to that of NASAUT 4G-A1, with the modification that each had successively a $0.25 \%$ decrement in carbon content. Thus, alloys $4 \mathrm{G}-\mathrm{A} 2$, $4 \mathrm{G}-\mathrm{A} 3$, and $4 \mathrm{G}-\mathrm{A} 4$ had $1.25,1.00$, and $0.75 \% \mathrm{C}$, respectively. Optical microscopic examinations revealed substantial modifications to the interdendritic carbides, as shown in Figs. 18 and 19.

3.8.1 Mechanical Properties Evaluation. The results of tensile tests on the carbon-modified alloys in the SBC condition are summarized graphically in Fig. 20 and tabularly in Table V. In Fig. 20, both the $0.2 \%$ offset yield stress and strain-to-failure are plotted as a function of carbon concentration at $600^{\circ} \mathrm{C}$. The yield strength decreases linearly with decreasing carbon content from 350 to $250 \mathrm{MPa}$ (a $30 \%$ decrease), while the strain-to-failure increases from 1 to $10 \%$ (a $1000 \%$ increase). Tests at other temperatures yield similar results. While these results demonstrate that high-ductility alloys are derivable through carbon modification, it may be cost ineffective to alter the composition of the alloy. The effects of the carbon reduction on low-cycle-fatigue performance of equiaxed-cast 4G-A alloys are summarized in Fig. 21 and Table VI. While there is significant scatter in the results, it is generally true that the LCF performance varies inversely with carbon content at $800^{\circ} \mathrm{C}$.

\subsection{Properties of Transversely Oriented, Directionally Solidified (Columnar Grain) Castings in the SBC Condition}

To determine the suitability of using directional solidification to produce automotive Stirling engine heater head components, the properties of directionally solidified castings in the SBC were investigated. During the initial phase of this program modification, significant problems were encountered in achieving castings with the proper chemistry. Initial DS casting attempts utilizing an atmosphere of argon at a pressure of $60 \mathrm{~Pa}(0.45$ torr) resulted in a significant deficit in $\mathrm{Mn}$, due to its volatility at the pouring temperature of $1500^{\circ} \mathrm{C}$. Ultimately, successful chemical compositions were achieved by reducing the pouring temperature to $1468^{\circ} \mathrm{C}$, increasing the argon pressure to approximately $50 \mathrm{kPa}$ ( 380 torr), using less reactive crucibles of $\mathrm{MgO}$, and utilizing crucible and mold covers to minimize volatile losses. These changes and a DS casting rate of $25 \mathrm{~cm} / \mathrm{h}$ were used successfully to produce all slab castings.

The macrograph of a typical, macroetched DS slab from which specimens were machined is presented in Fig. 22. The result of the directional solidification was a columnar-grained structure sharing a common (001) zone axis, which was within $10^{\circ}$ of being parallel to the DS axis. Transverse sectioning of the DS slabs indicated that they were sound castings with little or no pipe porosity, which rendered them suitable for machiring into test specimens. The as-cast microstructure for the DS form contained both primary, $\mathrm{Nb}$-rich MC carbides, which exhibited a script appearance, and blocky, $\mathrm{Cr}-$ and $\mathrm{Mn}$-rich $\mathrm{M}_{7} \mathrm{C}_{3}$ carbides. The representative microstructure for a longitudinal section is presented in Fig. 23.

3.9.1 Tensile Properties. Initially, the focus was placed on a determination of properties for specimens in which the stress or strain axis was transverse to the DS direction(DS/T). A constant total strain rate of $0.05 \mathrm{~min}^{-1}$ was employed for all monotonic tensile tests unless otherwise noted. 
The tensile properties of the transversely oriented DS material in the SBC condition are summarized in Table VIII. Graphical representations of the DS/T tensile yield and strain-to-failure properties are presented in Figs. 24 and 25. A comparison to the equiaxed-cast material, Figs. 10 and 11 , reveals the superiority in the strain-to-failure of the DS/T form throughout the temperature range investigated. Furthermore, the DS/T form exhibits higher Young's moduli essentially throughout the temperature range investigated. However, the equiaxed-cast form is clearly superior to the DS/T form in terms of the $0.2 \%$ offset yield stress and ultimate tensile stress (not shown), particularly at temperatures between 22 and $400^{\circ} \mathrm{C}$.

3.9.2 Fracture Behavior at $22^{\circ} \mathrm{C}$. Some very interesting and unexpected results have been obtained from an investigation into the fracture behavior of transversely and longitudinally oriented NASAUT 4G-A1 in the SBC condition. Initial problems in precracking the brittle alloy at room temperature were overcome by cycling at a stress intensity which was only slightly greater than the ultimate $\mathrm{K}_{\mathrm{IC}}$ as determined from the quasi-static fracture of the fatigue-precracked, compact tension specimens. A schematic diagram illustrating the two orientations investigated is given in Fig. 26. Interestingly and unexpectedly, the transverse ( $\mathrm{T}-\mathrm{L}$ ) orientation, in which the crack plane lay parallel to the DS axis, exhibited a plane-strain fracture toughness which was more than twice the value in the longitudinal $\left(\mathrm{L}-\mathrm{T}\right.$ ) orientation, $23.0 \mathrm{MPa} \bullet \mathrm{m}^{1 / 2}$ and $10.0 \mathrm{MPa} \bullet \mathrm{m}^{1 / 2}$, respectively, as summarized in Table IX. For the former, gross examination of the fracture surfaces revealed a less-planar fracture path which appeared to follow the dendrite cores.

In contrast, the fracture surface of the $\mathrm{L}-\mathrm{T}$ orientation was quite flat and the dendrite cores were fractured without much energy absorption. The resulting surface resembled what has been termed a "fossil record" morphology, with occasional dendrite cores having been extracted from the alloy matrix. Low-magnification fractographs of the two orientations are shown in Fig. 27. As shown clearly in Fig. 28, ductile tearing through the dendrite cores and cleavage across the interdendritic carbide network were the active failure mechanisms for the $\mathrm{T}-\mathrm{L}$ orientation. In addition to the dendrite core identified as " $\mathrm{A}$ " and positioned on the left side of Fig. 28a, a secondary dendrite arm from an adjacent dendrite (feature " $B$ ") fractured in a ductile manner, as well.

Additional SEM was devoted to the resolution of the mechanism which led to the toughening of the alloy in the T-L orientation by sectioning the fractured specimens as shown schematically in Fig. 29. Examination of Fig. 30 for the L-T orientation reveals that the fracture path was directly through the interdendritic carbide network, between the secondary dendrite arms. Limited secondary cracking is clear from this micrograph, also. Secondary cracking was much more prevalent in the T-L orientation, however, as shown in Fig. 31. The creation of this additional crack surface area in the bifurcated, secondary cracks has required additional energy input, the result of which was higher toughness for the T-L orientation.

3.9.3 Low-Cycle-Fatigue Behavior. In a similar manner to the procedures and results presented earlier for the equiaxed-cast form, the low-cycle-fatigue behavior of the SBC, DS/T form of NASAUT 4G-A1 has been characterized at the single temperature of $800^{\circ} \mathrm{C}$. The results from these tests have been summarized graphically in Fig. 32 and tabularly in Table X. While a linear fit to the data may be forced as shown by the solid line, the dashed line, which represents a least-squares fit to a quadratic equation, improves the quality of the fit. Deviations from linearity for fully logarithmic 
graphs of strain-life data, the so-called Coffin-Manson relationship (Refs. 9 and 10), are not isolated. For example, Cooper and Fine (Ref. 11) ascribed deviations from linearity in the endurance behavior of vacuum-melted $\alpha$-iron to the operation of two independent processes, those of microcrack initiation and propagation, among others. Clearly, the mechanisms which operate actively during these independent processes vary.

Also bothersome in Fig. 32 is the greater scatter in the lifetimes-to-failure compared to the equiaxed-cast behavior ( $c f$. Fig. 13). The comparatively greater degree of scatter may be ascribable, in part, to the brittle fracture paths which have been observed to operate during quasi-static fracture, as documented above.

3.9.4 High-Cycle-Fatigue Behavior. HCF tests have been conducted on the SBC, DS/T $4 \mathrm{G}-\mathrm{A} 1$ alloy in a similar manner to that reported above for the equiaxed-cast material. A sinusoidal waveform utilizing a cyclic frequency $20 \mathrm{~Hz}$ and an R-ratio of 0.1 has been used throughout the HCF testing. The range of temperatures investigated has been from $22^{\circ} \mathrm{C}$ to $800^{\circ} \mathrm{C}$, inclusive. The results are summarized graphically in Figs. 17 and 33-36 and tabularly in Tables XI through XVI. While the $\mathrm{DS} / \mathrm{T}$ form seems to exhibit parity or superiority at the two lower temperatures of $22^{\circ} \mathrm{C}$ and $200^{\circ} \mathrm{C}$, this trend reverses quickly for tests conducted at the intermediate temperature of $400^{\circ} \mathrm{C}$, as shown in Fig. 35. Parity in HCF lives is reestablished at $600{ }^{\circ} \mathrm{C}$ and is retained at $800^{\circ} \mathrm{C}$, as shown in Figs. 36 and 17 . For convenience in comparing the results, HCF data for the equiaxed-cast form have been superimposed onto the graphs for the DS/T form. As noted for the results from the LCF testing of the $\mathrm{DS} / \mathrm{T}$ form, a disturbingly high degree of scatter is evident for the HCF results. In general, the degree of scatter has been observed to increase with increasing temperature.

Attempts to understand this scatter by applying SEM to the fracture surfaces were essentially unsuccessful. Similarly, attempts to understand the scatter according to the variation in columnar grain and carbide sizes as a consequence of the specimen position within the slab casting, proved inconclusive.

\subsection{Properties of Longitudinally Oriented, Directionally Solidified (Columnar Grain) Castings in the SBC Condition}

3.10.1 Creep Behavior. The characterization of the creep behavior of SBC, DS/L 4G-A1 was investigated at the single temperature of $800^{\circ} \mathrm{C}$. The objective was to determine whether the longitudinal orientation would satisfy the design requirement of achieving a creep strain of not greater than $2 \%$ in $500 \mathrm{~h}$ at the design stress of $120 \mathrm{MPa}$. The results of this creep testing are presented in Table XVII. Clearly, the longitudinal orientation of DS $4 \mathrm{G}-\mathrm{A} 1$ is not capable of sustaining this severity of creep loading, rupturing in an average of $16.4 \mathrm{~h}$ under these design conditions. In order to determine a lower limit on the stress which would result in a maximum of $2 \%$ strain in $500 \mathrm{~h}$ at $800^{\circ} \mathrm{C}$, the stress was lowered to $50 \mathrm{MPa}$, which sustained the $500 \mathrm{~h}$ exposure without having achieved a creep strain of even $1 \%$. At the creep stress of $86 \mathrm{MPa}$, the average time to the achievement of $2 \%$ creep strain was $42.5 \mathrm{~h}$.

3.10.2 Low-Cycle-Fatigue Behavior. The low-cycle-fatigue behavior of SBC, DS/L 4G-A1 has been investigated at the temperatures of $22^{\circ} \mathrm{C}, 400^{\circ} \mathrm{C}$, and $800^{\circ} \mathrm{C}$. The results from these tests are presented graphically in Figs. 37-39 and tabularly in Table XVII. While the equiaxed-cast form is 
clearly superior at $22^{\circ} \mathrm{C}$, parity between the two forms is achieved quickly for the two higher temperatures of $400^{\circ} \mathrm{C}$ and $800^{\circ} \mathrm{C}$. Again evident from Fig. 39 is the nonlinearity between strain amplitude and cycles-to-failure as graphed in fully logarithmic coordinates.

3.10.3 High-Cycle-Fatigue Behavior. The high-cycle-fatigue behavior of the SBC, DS/L form has been investigated at the temperatures of $22^{\circ} \mathrm{C}, 400^{\circ} \mathrm{C}$, and $800^{\circ} \mathrm{C}$. The results from these tests are presented graphically in Figs. 40-42 and tabularly in Table XIX. As for the DS/T form reported above, the HCF results for the DS/L form exhibit a high degree of scatter. This scatter is particularly prevalent at the temperatures of $22^{\circ} \mathrm{C}$ and $400^{\circ} \mathrm{C}$, while being somewhat reduced for the data at $800^{\circ} \mathrm{C}$. Comparison to the equiaxed-cast form reveals that the HCF performance of the DS/L form is inferior, with the possible exception being at the temperature of $800^{\circ} \mathrm{C}$, where the lifetimes-to-failure are similar.

3.10.4 Tensile Properties. The tensile properties for NASAUT 4G-A1 in the SBC, DS/L condition are presented in Table XX. It should be noted that the strain rate was inconsistent over the range of temperatures investigated due to vendor error, being $0.05 \mathrm{~min}^{-1}$ for the tests conducted at 22 and $400^{\circ} \mathrm{C}$ and $0.005 \mathrm{~min}^{-1}$ for the tests conducted at 200,600 , and $800^{\circ} \mathrm{C}$. This error may cause difficulty in drawing exact comparisons in the $0.2 \%$ offset and ultimate tensile stresses among the $\mathrm{DS} / \mathrm{L}, \mathrm{DS} / \mathrm{T}$, and equiaxed forms due to the moderate strain-rate sensitivity of austenitic alloys at elevated temperatures; however, it is expected to have a negligible effect on the strain-to-failure values. As expected, the elastic moduli are consistently lower for the DS/L form compared to both the equiaxed and DS/T forms, due to the (001) tensile orientation of the DS/L form. While the $0.2 \%$ offset yield and ultimate tensile stresses are comparable for the two orientations of the DS form in the SBC condition throughout the temperature range investigated, the ductility as measured by strain-to-failure is approximately equal at the two lower temperatures but is greatly superior for the DS/L compared to both the DS/T and equiaxed forms (in SBC condition) at higher temperatures, especially at $800^{\circ} \mathrm{C}$ (cf. Tables I, VIII, and XX).

\subsection{SUMMARIZING REMARKS AND CONCLUSIONS}

The completion of this program has resulted in the development of a cast, iron-based superalloy which may be processed in either conventional, equiaxed form or by directional solidification, in which case the (001) zone axis lies parallel or nearly parallel to the DS axis. While the alloy is high in chromium, it is not considered strategic because it does not rely on foreign supplies; rather, because of the high carbon content of the final alloy developed, $1.5 \%$, the ferro-chromium deposits indigenous to the western U.S. are rendered viable sources. For the equiaxed form, the as-cast condition exhibits slightly inferior tensile strength but slightly superior ductility compared to the SBC condition. Similarly, the two additional heat treatments, the under-aged and super-aged conditions, display significantly superior strengths but fail to exhibit the monotonic strain tolerance of the as-cast condition. The low-cycle-fatigue performance in the as-cast condition is greatly superior to that in the SBC condition for temperatures less than $600^{\circ} \mathrm{C}$, above which point the performance of the two conditions is approximately equal. For the HCF behavior, limited data indicate that the SBC condition is superior to the as-cast condition except at the extreme temperatures of $22^{\circ} \mathrm{C}$ and $800^{\circ} \mathrm{C}$. In comparison to XF-818, the mechanical properties of equiaxed-cast NASAUT $4 \mathrm{G}-\mathrm{A} 1$ are 
equivalent or slightly superior; the greatest and most dramatic superiority of the latter is its resistance to oxidation, corrosion, and sulfidation. Decreasing the carbon content of the alloy from 1.5 to $0.75 \%$ produces an increase in the strain-to-failure and a concomitant decrease in tensile strength. The LCF performance varies approximately inversely with carbon content.

By comparison to the equiaxed-cast form of NASAUT 4G-A1, the transversely oriented DS form in the SBC condition is slightly to considerably weaker in monotonic tension and approximately equal in strain-to-failure throughout the temperature range investigated. The HCF behavior of the $\mathrm{SBC}, \mathrm{DS} / \mathrm{T}$ form is somewhat inferior to the equiaxed form at the lower temperatures but approaches parity at temperatures of $600^{\circ} \mathrm{C}$ and $800^{\circ} \mathrm{C}$. Significant scatter in the $\mathrm{HCF}$ data is an increasing problem at the higher temperatures of 400 through $800^{\circ} \mathrm{C}$.

Interestingly and surprisingly, the fracture toughness of the DS form in the transverse (T-L) orientation is approximately two times superior to that in the longitudinal (L-T) orientation. The reasons for this superiority are that the fracture surface follows the tougher dendrite cores and that the cracks tend to bifurcate in the T-L orientation; conversely, the fracture surface for the T-L orientation is rather flat and cleaves across the interdendritic carbide network.

\section{ACKNOWLEDGEMENTS}

The authors wish to acknowledge fruitful discussions and interactions with M. J. Cronin and J. A. Corey of Mechanical Technologies, Inc., Latham, NY. R. J. Henricks, A. S. Grot, and K. E. Taylor from the experimental foundry at Pratt \& Whitney Division of United Technologies Corporation are gratefully acknowledged for their cooperation and efforts to produce the DS slab castings, from which properties in the simulated-braze-cycled (SBC) condition were determined. The able leadership of the technical program monitors, C. M. Scheuermann and R. H. Titran of NASA/Lewis Research Center, is acknowledged with appreciation.

\subsection{REFERENCES}

1. D. J. Schmatz and V. F. Zackay, Trans. ASM, 51, 299, 1959.

2. J. B. See, J. Met., 32 (4), 52, April 1980.

3. F. D. Lemkey, E. R. Thompson, J. C. Schuster, and H. Nowotny, in In Situ Composites IV, F. D. Lemkey, H. E. Cline, and M. McLean, eds., Elsevier Science Publising Co., Inc., New York, 1982, p. 31.

4. Metals Week, Nov. 23, 1984.

5. American Metal Market/Metal Working News, Nov. 19, 1984.

6. F. D. Lemkey, J. G. Smeggil, R. S. Bailey, J. C. Schuster, and H. Nowotny, High Temperatures-High Pressures, 18, 283, 1986. 
7. M. K. Lewis and B. H. Attersley, Acta Metall., 13, 1163, 1965.

8. ASE Development Program Mod II: Basic Stirling Engine, Vol. I, Design Review Report, MTI Report \#85TR24, April 2, 1985.

9. L. F. Coffin, Trans. ASME, 76, 931, 1954.

10. S. S. Manson, NACA Technical Note 2933, 1954.

11. C. V. Cooper and M. E. Fine, Scripta Metall., 18, 593, 1984.

12. F. D. Lemkey, H. Gupta, H. Nowotny, and S. F. Wayne, J. Mater. Sci., 19, 965, 1984. 


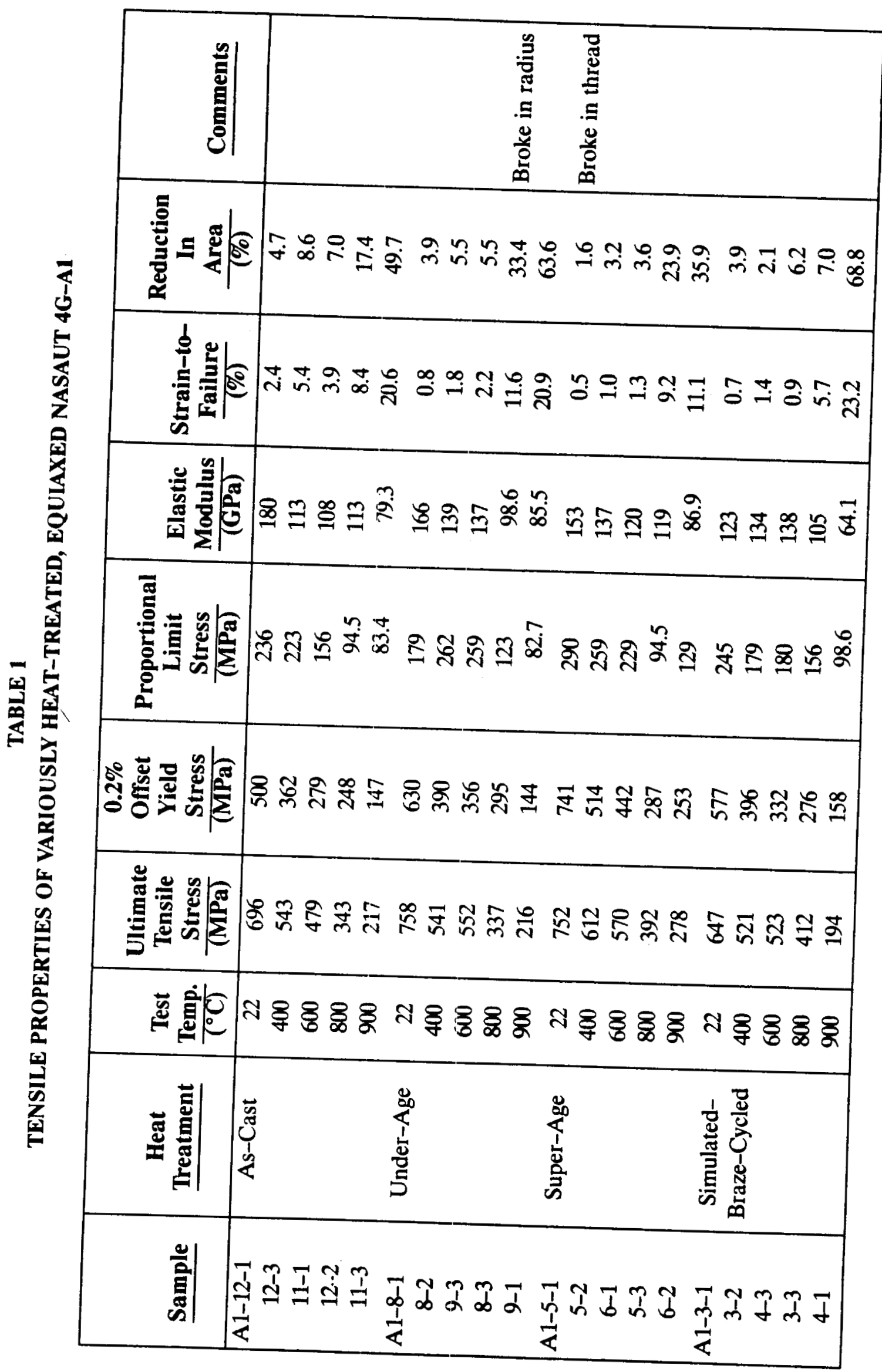


TABLE II

LOW-CYCLE-FATIGUE DATA FOR EQUIAXED NASAUT 4G-A1

\begin{tabular}{|c|c|c|c|c|}
\hline Spec. No. & Heat Treatment & $\begin{array}{l}\text { Total Strain } \\
\text { Amplitude, } \\
\frac{\Delta \epsilon_{\mathrm{T}}}{2}(\%)\end{array}$ & $\begin{array}{c}\text { Test } \\
\text { Temp. }\left({ }^{\circ} \mathrm{C}\right)\end{array}$ & $\begin{array}{c}\text { Cycles-to- } \\
\text { Failure, } \\
\mathrm{N}_{\mathrm{f}}\end{array}$ \\
\hline A1-24-1 & As-cast & \pm 0.4 & 22 & 1129 \\
\hline $22-1$ & $"$ & \pm 0.4 & 200 & 3102 \\
\hline $20-1$ & $"$ & \pm 0.4 & 400 & 983 \\
\hline $21-1$ & $"$ & \pm 0.4 & 700 & 800 \\
\hline $17-2$ & $"$ & \pm 0.2 & 800 & 9412 \\
\hline $16-2$ & $"$ & \pm 0.4 & 800 & 921 \\
\hline $14-2$ & $"$ & \pm 0.6 & 800 & 148 \\
\hline $15-2$ & $"$ & \pm 0.8 & 800 & 110 \\
\hline $47-1$ & Simulated- & \pm 0.4 & 22 & 100 \\
\hline \51-1 & Braze-Cycled & \pm 0.4 & 200 & 1069 \\
\hline $42-1$ & $"$ & \pm 0.4 & 400 & 429 \\
\hline $41-1$ & $"$ & \pm 0.4 & 600 & 767 \\
\hline $43-1$ & $"$ & \pm 0.4 & 700 & 730 \\
\hline $39-1$ & $"$ & \pm 0.4 & 800 & 905 \\
\hline $40-1$ & $"$ & \pm 0.2 & 800 & 2959 \\
\hline $38-1$ & $"$ & \pm 0.6 & 800 & 227 \\
\hline $37-1$ & $"$ & \pm 0.8 & 800 & 193 \\
\hline
\end{tabular}


TABLE III

LOW-CYCLE-FATIGUE RESULTS FROM SIMULATED-BRAZE-CYCLED, EQUIAXED NASAUT 4G-A1

\begin{tabular}{|c|c|c|c|}
\hline $\begin{array}{c}\text { Specimen } \\
\text { Number }\end{array}$ & $\begin{array}{c}\text { Total Strain } \\
\text { Amplitude, } \frac{\Delta \epsilon_{\mathrm{T}}}{2}(\%)\end{array}$ & $\begin{array}{c}\text { Cycles-to- } \\
\text { Failure, } \mathbf{N}_{\mathbf{f}}\end{array}$ & $\begin{array}{c}\text { Test Temperature } \\
\left({ }^{\circ} \mathrm{C}\right)\end{array}$ \\
\hline A1-25-1 & \pm 0.15 & $>268,310$ & 22 \\
A1-26-1 & \pm 0.20 & 6,335 & 22 \\
A1-27-1 & \pm 0.25 & 2,892 & 22 \\
A1-23-1 & \pm 0.30 & 284 & 22 \\
A1-50-1 & \pm 0.15 & 11,334 & 800 \\
A1-49-1 & \pm 0.20 & 9,628 & 800 \\
A1-45-1 & \pm 0.30 & 1,902 & 800 \\
A1-48-1 & \pm 0.40 & 636 & 800 \\
\hline
\end{tabular}


TABLE IV

HIGH-CYCLE-FATIGUE RESULTS

FOR EQUIAXED NASAUT 4G-AI

\begin{tabular}{|c|c|c|c|c|}
\hline Spec. No. & Heat Treatment & Test Temp. $\left({ }^{\circ} \mathrm{C}\right)$ & $\sigma_{\max }(\mathrm{MPa})$ & $\begin{array}{l}\text { Cycles-to- } \\
\text { Failure, } N_{f}\end{array}$ \\
\hline A1-35-1 & As-Cast & 22 & 270 & $1.1 \times 10^{7}+$ \\
\hline$A 1-32-2$ & $"$ & 22 & 621 & $30.9 \times 10^{3}$ \\
\hline A1-35-1 & $"$ & 200 & 552 & $1.5 \times 10^{3}$ \\
\hline$A 1-31-2$ & $"$ & 400 & 483 & $15.4 \times 10^{3}$ \\
\hline A1-32-1 & $"$ & 600 & 316 & $11.9 \times 10^{6}+$ \\
\hline A1-34-1 & $"$ & 600 & 379 & $9.3 \times 10^{6}+$ \\
\hline$A 1-30-2$ & $"$ & 600 & 414 & $240.0 \times 10^{3}$ \\
\hline A1-33-1 & $"$ & 800 & 316 & $190.0 \times 10^{3}$ \\
\hline A1-58-2 & $\begin{array}{l}\text { Simulated- } \\
\text { Braze-Cycled }\end{array}$ & 22 & 621 & $0.3 \times 10^{3}$ \\
\hline$A 1-57-2$ & $"$ & 200 & 552 & $11.3 \times 10^{3}$ \\
\hline$A 1-54-1$ & $"$ & 400 & 483 & $46.4 \times 10^{3}$ \\
\hline A1-53-1 & $"$ & 600 & 414 & 541.1 \\
\hline A1-36-2 & $"$ & 800 & 316 & 18.6 \\
\hline
\end{tabular}


TABLE V

TENSILE DATA FOR CARBON-MODIFIED NASAUT ALLOYS

\begin{tabular}{|c|c|c|c|c|c|c|}
\hline $\begin{array}{c}\text { Specimen } \\
\text { Designation }\end{array}$ & $\begin{array}{l}\text { Test } \\
\text { Temp. } \\
\left({ }^{\circ} \mathrm{C}\right)\end{array}$ & $\begin{array}{c}\text { Elastic } \\
\text { Modulus } \\
\text { (GPa) }\end{array}$ & $\begin{array}{c}\text { Proportional } \\
\text { Limit } \\
\text { Stress } \\
(\mathrm{MPa})\end{array}$ & $\begin{array}{l}0.2 \% \text { Offset } \\
\text { Yield Stress } \\
(\mathrm{MPa})\end{array}$ & $\begin{array}{c}\text { Ultimate } \\
\text { Tensile } \\
\text { Stress } \\
\text { (MPa) }\end{array}$ & $\begin{array}{c}\text { Strain-to- } \\
\text { Failure } \\
(\%)\end{array}$ \\
\hline $4 \mathrm{G}-\mathrm{A} 2-1$ & 22 & 182.0 & 196.5 & 505.4 & 646.1 & .875 \\
\hline A2-2 & 200 & 188.9 & 139.3 & 376.5 & 592.3 & 1.97 \\
\hline A2-3 & 400 & 152.4 & 196.5 & 357.9 & 568.8 & 2.20 \\
\hline$A 2-4$ & 600 & 140.7 & 168.2 & 329.6 & 512.3 & 2.95 \\
\hline A2-5 & 800 & 135.1 & 133.1 & 224.8 & 337.2 & 14.3 \\
\hline $4 G-A 3-1$ & 22 & 184.1 & 167.5 & 438.5 & 724.7 & 2.74 \\
\hline A3-2 & 200 & 168.9 & 180.0 & 345.4 & 601.2 & 3.63 \\
\hline$A 3-3$ & 400 & 138.6 & 189.6 & 308.9 & 554.4 & 3.95 \\
\hline A3-4 & 600 & 133.8 & 112.4 & 253.0 & 505.4 & 6.30 \\
\hline$A 3-5$ & 800 & 174.4 & 8.3 .4 & 215.8 & 309.6 & 8.20 \\
\hline $4 \mathrm{G}-\mathrm{A} 4-1$ & 22 & 190.3 & 222.9 & 432.0 & 717.8 & 2.15 \\
\hline A4-2 & 200 & 164.8 & 193.1 & 322.7 & 624.7 & 5.90 \\
\hline A4-3 & 400 & 168.2 & 176.5 & 291.7 & 617.8 & 8.10 \\
\hline A4-4 & 600 & 168.2 & 152.4 & 248.9 & 525.4 & $6.4^{*}$ \\
\hline A4-5 & 800 & 120.0 & 110.3 & 200.6 & 283.4 & $11.4^{*}$ \\
\hline
\end{tabular}


TABLE VI

LOW-CYCLE-FATIGUE RESULTS FOR CARBON-

MODIFIED NASAUT 4G-AI ALLOYS (EQUIAXED) AT $22^{\circ} \mathrm{C}$

\begin{tabular}{|c|c|c|c|}
\hline $\begin{array}{c}\text { Alloy } \\
\text { Chemistry }\end{array}$ & $\begin{array}{c}\text { Total Strain } \\
\text { Amplitude, } \frac{\Delta \epsilon_{\mathrm{T}}}{2}(\%)\end{array}$ & $\begin{array}{l}\text { Cycles-to- } \\
\text { Failure, } \mathbf{N}_{\mathbf{f}}\end{array}$ & $\begin{array}{l}\text { Failure } \\
\text { Location }\end{array}$ \\
\hline 西 & $\begin{array}{l} \pm 0.2 \\
\pm 0.4 \\
\pm 0.6 \\
\pm 0.8\end{array}$ & $\begin{array}{r}7267 \\
539 \\
377 \\
145\end{array}$ & $\begin{array}{l}\text { gauge } \\
\text { gauge } \\
\text { shoulder } \\
\text { at notch }\end{array}$ \\
\hline $4 \mathrm{G}-\mathrm{A} 3$ & $\begin{array}{l} \pm 0.2 \\
\pm 0.4 \\
\pm 0.6 \\
\pm 0.8\end{array}$ & $\begin{array}{r}6577 \\
1789 \\
266 \\
337\end{array}$ & $\begin{array}{l}\text { gauge } \\
\text { gauge } \\
\text { gauge } \\
\text { gauge }\end{array}$ \\
\hline $4 G-A 4$ & $\begin{array}{l} \pm 0.2 \\
\pm 0.4 \\
\pm 0.6 \\
\pm 0.8\end{array}$ & $\begin{array}{r}7593 \\
1181 \\
480 \\
289\end{array}$ & $\begin{array}{l}\text { gauge } \\
\text { gauge } \\
\text { at notch } \\
\text { gauge }\end{array}$ \\
\hline
\end{tabular}


TABLE VII

CREEP RESULTS FOR CARBON-MODIFIED NASAUT 4G-A1 ALLOYS (EQUIAXED)

\begin{tabular}{|c|c|c|c|c|}
\hline Alloy & $\begin{array}{c}\text { Test Temp. } \\
\left({ }^{\circ} \mathbf{C}\right)\end{array}$ & $\begin{array}{c}\text { Stress } \\
(\mathbf{M P a})\end{array}$ & $\begin{array}{c}\mathbf{t}_{2 \%} \\
(\mathbf{h r})\end{array}$ & $\begin{array}{c}\mathbf{t}_{\mathbf{R}} \\
(\mathbf{h r})\end{array}$ \\
\hline $4 \mathrm{G}-\mathrm{A} 2$ & 700 & 345 & 10.1 & 7.1 \\
$4 \mathrm{G}-\mathrm{A} 2$ & 800 & 241 & $*$ & $*$ \\
$4 \mathrm{G}-\mathrm{A} 2$ & 900 & 103 & 7.0 & 11.3 \\
& & & & \\
$4 \mathrm{G}-\mathrm{A3}$ & 700 & 345 & 0.3 & 0.07 \\
$4 \mathrm{G}-\mathrm{A3}$ & 800 & 241 & 0.02 & 0.01 \\
4G-A3 & 900 & 103 & 1.5 & 20.0 \\
& & & & $*$ \\
4G-A4 & 700 & 345 & 0.3 & 0.3 \\
4G-A4 & 800 & 241 & 0.05 & 18.75 \\
4G-A4 & 900 & 103 & $*$ & $*$ \\
\hline Failed upon loading
\end{tabular}


TABLE VIII

TENSILE PROPERTIES OF TRANSVERSELY ORIENTED, DIRECTIONALLY SOLIDIFIED NASAUT 4G-A1 IN SIMULATED-BRAZE-CYCLED CONDITION

\begin{tabular}{|c|c|c|c|c|c|}
\hline TEST & ULTIMATE & O.2\% OFFSET & & & \\
TEMPERATURE & TENSILE & YIELD & PROPORTIONAL & ELASTIC & STRAIN-TO- \\
$\left({ }^{\circ} \mathbf{C}\right)$ & $(\mathrm{MPA})$ & (MPA) & $(\mathrm{MPA})$ & $(\mathrm{GPA})$ & $(\%)$ \\
\hline 22 & 514.0 & 357.6 & 154.3 & 187.9 & 0.96 \\
200 & 490.6 & 337.0 & 166.1 & 153.5 & 1.25 \\
400 & 441.0 & 311.4 & 198.8 & 126.9 & 1.10 \\
600 & 427.2 & 281.1 & 172.9 & 146.6 & 1.45 \\
800 & 264.6 & 192.2 & 111.6 & 105.5 & 7.44 \\
\hline
\end{tabular}


TABLE IX

PLANE STRAIN FRACTURE TOUGHNESS $\left(K_{I c}\right)$ VALUES FOR

SIMULATED-BRAZE-CYCLED, DS NASAUT 4G-AI AT $22^{\circ} \mathrm{C}$

\begin{tabular}{|c|c|c|c|c|}
\hline & Specimen No. & Orientation & $\begin{array}{l}\text { Max. Load } \\
\qquad(\mathbf{k N})\end{array}$ & $\begin{array}{l}\text { Calculated } \mathrm{K}_{\mathrm{Ic}} \\
\left(\mathrm{MPa} \cdot \mathbf{m}^{1 / 2}\right)\end{array}$ \\
\hline & $5078-\mathrm{A}-01$ & Longitudinal (L-T) & 10.0 & $21.0^{\mathrm{A}}$ \\
\hline & $5078-\mathrm{A}-02$ & Longitudinal (L-T) & 4.0 & 10.0 \\
\hline & $5078-\mathrm{A}-03$ & Transverse (T-L) & 8.0 & 20.2 \\
\hline & $5078-\mathrm{A}-04$ & Transverse (T-L) & 11.3 & 24.3 \\
\hline & $5078-\mathrm{A}-05$ & Longitudinal (L-T) & 7.1 & $12.0^{\mathrm{B}}$ \\
\hline & $5078-\mathrm{A}-06$ & Transverse (T-L) & 11.5 & 24.4 \\
\hline \multicolumn{5}{|c|}{$\begin{array}{l}A \text { - failed upon initial loading for precracking }-K_{I c} \text { based on initial } K_{\max } \\
B \text { - failed after } 2000 \text { cycles of precracking }-K_{I c} \text { based on } K_{\max } \text { for precracking } \\
\text { assuming zero sub-critical crack growth. }\end{array}$} \\
\hline
\end{tabular}


TABLE X

LOW-CYCLE-FATIGUE RESULTS AT $800^{\circ} \mathrm{C}$ FOR TRANSVERSELY ORIENTED, DS NASAUT 4G-AI IN SIMULATED-BRAZE-CYCLED CONDITION

\begin{tabular}{|c|c|}
\hline $\begin{array}{c}\text { Total Strain Amplitude, } \\
\Delta \epsilon_{\mathbf{T}} / 2(\%)\end{array}$ & Cycles-to-Failure, \\
\hline \pm 0.10 & $\mathbf{N}_{\mathbf{f}}$ \\
\pm 0.10 & $1,150,000$ \\
\pm 0.15 & $1,500,000$ \\
\pm 0.15 & 88,540 \\
\pm 0.20 & 36,950 \\
\pm 0.20 & 3,675 \\
\pm 0.20 & 14,040 \\
\pm 0.25 & 6,650 \\
\pm 0.25 & 4,970 \\
\pm 0.30 & 1,830 \\
\pm 0.30 & 930 \\
\hline
\end{tabular}


TABLE XI

HIGH-CYCLE-FATIGUE RESULTS OF DS TRANSVERSE AND

EQUIAXED NASAUT 4G-A1 AT $22^{\circ} \mathrm{C}$

\begin{tabular}{|c|c|c|c|c|c|}
\hline $\begin{array}{c}\text { Specimen } \\
\text { Number }\end{array}$ & Form & $\begin{array}{c}\text { Heat } \\
\text { Treatment }\end{array}$ & $\begin{array}{c}\sigma_{\max } \\
(\mathbf{M P a})\end{array}$ & $\begin{array}{c}\text { Cycles-to- } \\
\text { Failure, } \\
\mathbf{N}_{\mathrm{f}}\end{array}$ & $\begin{array}{c}\text { Failure } \\
\text { Location }\end{array}$ \\
\hline 5076-A-8B & $\mathrm{DS} / \mathrm{T}$ & Simulated-Braze-Cycled & 551 & 10 & gauge \\
\hline $5077-\mathrm{B}-8 \mathrm{~A}$ & $"$ & $"$ & 413 & 29,900 & gauge \\
\hline $5077-\mathrm{A}-3 \mathrm{~A}$ & $"$ & $"$ & 413 & 24,650 & gauge \\
\hline $5076-\mathrm{A}-9 \mathrm{~A}$ & $"$ & $"$ & 379 & 188,200 & gauge \\
\hline 5076-A-10A & $"$ & $"$ & 379 & 93,700 & gauge \\
\hline 5077-B-8B & $"$ & $"$ & 379 & 189,700 & gauge \\
\hline 5090-03-B-4A & $"$ & $"$ & 345 & 991,300 & gauge \\
\hline 5090-03-B-4B & $"$ & $"$ & 345 & $1,341,900$ & gauge \\
\hline $5076-A-4 B$ & $"$ & $"$ & 275 & 912,200 & thread \\
\hline 5077-A-3B & $"$ & $"$ & 275 & 838,860 & thread \\
\hline $5076-A-8 A$ & $"$ & $"$ & 275 & $>12,000,000$ & none \\
\hline $5090-03-\mathrm{B}-8 \mathrm{~B}$ & $"$ & $"$ & 275 & $>10,000,000$ & none \\
\hline A1-32-2 & Equiaxed & As-Cast & 621 & 30,900 & gauge \\
\hline A1-35-1 & $"$ & $"$ & 270 & $>11,000,000$ & none \\
\hline A1-58-2 & $"$ & Simulated-Braze-Cycled & 621 & 300 & gauge \\
\hline
\end{tabular}


TABLE XII

HIGH-CYCLE-FATIGUE RESULTS OF DS TRANSVERSE AND

EQUIAXED NASAUT 4 G-AI AT $200^{\circ} \mathrm{C}$

\begin{tabular}{|c|c|c|c|c|c|}
\hline $\begin{array}{l}\text { Specimen } \\
\text { Number }\end{array}$ & Form & $\begin{array}{c}\text { Heat } \\
\text { Treatment }\end{array}$ & $\begin{array}{c}\sigma_{\max } \\
(\mathbf{M P a})\end{array}$ & $\begin{array}{c}\text { Cycles-to- } \\
\text { Failure, } \\
\mathbf{N}_{\mathbf{f}}\end{array}$ & $\begin{array}{l}\text { Failure } \\
\text { Location }\end{array}$ \\
\hline $5090-03-B-7 A$ & $\mathrm{DS} / \mathrm{T}$ & Simulated-Braze-Cycled & 413 & 16,700 & gauge \\
\hline $5090-01-A-8 A$ & $"$ & $"$ & 413 & 18,100 & gauge \\
\hline $5090-03-B-6 B$ & $"$ & $"$ & 379 & 47,000 & gauge \\
\hline $5076-A-2 A$ & $"$ & $"$ & 379 & 101,200 & gauge \\
\hline $5077-A-4 B$ & " & $”$ & 379 & 109,100 & gauge \\
\hline $5090-03-B-6 A$ & $"$ & $"$ & 345 & 81,100 & gauge \\
\hline $5077-\mathrm{A}-8 \mathrm{~A}$ & $"$ & $"$ & 345 & 185,700 & gauge \\
\hline $5077-A-4 A$ & $"$ & $"$ & 275 & $>10,000,000$ & none \\
\hline $5090-01-A-8 B$ & $"$ & $"$ & 275 & $>10,000,000$ & none \\
\hline A1-35-1 & Equiaxed & As-Cast & 552 & 1,500 & gauge \\
\hline A1-57-2 & $"$ & Simulated-Braze-Cycled & 552 & 11,300 & gauge \\
\hline
\end{tabular}


TABLE XIII

HIGH-CYCLE-FATIGUE RESULTS OF DS TRANSVERSE AND

EQUIAXED NASAUT 4G-A1 AT $400^{\circ} \mathrm{C}$

\begin{tabular}{|c|c|c|c|c|c|}
\hline $\begin{array}{l}\text { Specimen } \\
\text { Number }\end{array}$ & Form & $\begin{array}{c}\text { Heat } \\
\text { Treatment }\end{array}$ & $\begin{array}{c}\sigma_{\max } \\
(\mathbf{M P a})\end{array}$ & $\begin{array}{c}\text { Cycles-to- } \\
\text { Failure, } \\
\mathbf{N}_{\mathbf{f}}\end{array}$ & $\begin{array}{l}\text { Failure } \\
\text { Location }\end{array}$ \\
\hline $5076-\mathrm{A}-11 \mathrm{~A}$ & $\mathrm{DS} / \mathrm{T}$ & Simulated-Braze-Cycled & 413 & 6,200 & gauge \\
\hline $5090-01-A-6 A$ & ” & $"$ & 413 & 9,900 & gauge \\
\hline 5077-A-8B & $"$ & $"$ & 413 & 38,900 & gauge \\
\hline 5077-B-7B & $"$ & $"$ & 379 & 219,300 & gauge \\
\hline $5090-03-B-3 A$ & $"$ & $"$ & 379 & 731,400 & gauge \\
\hline $5090-03-B-7 B$ & $"$ & $"$ & 345 & $>10,000,000$ & none \\
\hline $5090-03-B-1 B$ & $"$ & $”$ & 345 & 371,800 & gauge \\
\hline $5090-03-B-2 A$ & $"$ & $"$ & 345 & $7,588,000$ & gauge \\
\hline $5090-03-B-1 A$ & $"$ & $"$ & 275 & $>10,000,000$ & none \\
\hline 5076-A-3A & ” & ” & $27 \dot{5}$ & $8,900,000$ & gauge \\
\hline A1-31-2 & Equiaxed & As-Cast & 483 & 15,400 & gauge \\
\hline$A 1-54-1$ & $"$ & Simulated-Braze-Cycled & 483 & 46,400 & gauge \\
\hline
\end{tabular}


TABLE XIV

HIGH-CYCLE-FATIGUE RESULTS OF EQUIAXED

NASAUT $4 G-A 1$ AT $800^{\circ} \mathrm{C}$

\begin{tabular}{|c|c|c|c|c|}
\hline $\begin{array}{l}\text { Specimen } \\
\text { Number }\end{array}$ & $\begin{array}{c}\text { Heat } \\
\text { Treatment }\end{array}$ & $\begin{array}{c}\sigma_{\max } \\
(\mathbf{M P a})\end{array}$ & $\begin{array}{c}\text { Cycles-to- } \\
\text { Failure, } \\
\mathbf{N}_{\mathrm{f}}\end{array}$ & $\begin{array}{l}\text { Failure } \\
\text { Location }\end{array}$ \\
\hline $9-1$ & Simulated-Braze-Cycled & 310 & 9,500 & gauge \\
\hline $9-2$ & $"$ & 310 & 5,500 & gauge \\
\hline $9-3$ & $"$ & 293 & 24,200 & gauge \\
\hline $9-4$ & $"$ & 293 & 14,700 & gauge \\
\hline $9-5$ & $"$ & 276 & 31,500 & gauge \\
\hline $9-6$ & $"$ & 276 & 32,100 & gauge \\
\hline 9-7 & $"$ & 265 & 42,700 & gauge \\
\hline $9-8$ & $"$ & 265 & 120,600 & gauge \\
\hline $9-9$ & $"$ & 241 & 164,100 & gauge \\
\hline $9-10$ & $"$ & 241 & 179,000 & gauge \\
\hline A1-33-1 & As-Cast & 316 & 190,000 & gauge \\
\hline$A 1-36-2$ & Simulated-Braze-Cycled & 316 & 9,500 & gauge \\
\hline
\end{tabular}


TABLE XV

HIGH-CYCLE-FATIGUE RESULTS OF DS TRANSVERSE AND

EQUIAXED NASAUT 4G-A1 AT $600^{\circ} \mathrm{C}$

\begin{tabular}{|c|c|c|c|c|c|}
\hline $\begin{array}{l}\text { Specimen } \\
\text { Number }\end{array}$ & Form & $\begin{array}{c}\text { Heat } \\
\text { Treatment }\end{array}$ & $\begin{array}{l}\sigma_{\max } \\
(\mathrm{MPa})\end{array}$ & $\begin{array}{c}\text { Cycles-to- } \\
\text { Failure, } \\
\mathbf{N}_{\mathbf{f}}\end{array}$ & $\begin{array}{l}\text { Failure } \\
\text { Location }\end{array}$ \\
\hline $5076-A-13$ & $\overline{\mathrm{DS} / \mathrm{T}}$ & Simulated-Braze-Cycled & 413 & 181,700 & gauge \\
\hline 5077-A-9A & $"$ & $"$ & 413 & 148,500 & gauge \\
\hline $5077-\mathrm{A}-12 \mathrm{~A}$ & $"$ & $"$ & 413 & 166,100 & gauge \\
\hline 5090-03-B-8A & $"$ & $"$ & 379 & 235,100 & gauge \\
\hline $5077-A-11 B$ & $"$ & $"$ & 379 & 174,200 & gauge \\
\hline $5090-03-B-2 B$ & $"$ & $"$ & 345 & $6,643,100$ & gauge \\
\hline $5076-\mathrm{A}-4 \mathrm{~A}$ & $"$ & $"$ & 345 & $7,414,300$ & gauge \\
\hline $5076-A-11 B$ & $"$ & $"$ & 279 & $>10,000,000$ & none \\
\hline A1-30-2 & Equiaxed & As-Cast & 414 & 240,000 & gauge \\
\hline A1-53-1 & $"$ & Simulated-Braze-Cycled & 414 & 8,000 & gauge \\
\hline
\end{tabular}


TABLE XVI

HIGH-CYCLE-FATIGUE RESULTS OF DS TRANSVERSE AND

EQUIAXED NASAUT $4 \mathrm{G}-A 1$ AT $800^{\circ} \mathrm{C}$

\begin{tabular}{|c|c|c|c|c|c|}
\hline $\begin{array}{l}\text { Specimen } \\
\text { Number }\end{array}$ & Form & $\begin{array}{c}\text { Heat } \\
\text { Treatment }\end{array}$ & $\begin{array}{c}\sigma_{\max } \\
(\mathbf{M P a})\end{array}$ & $\begin{array}{c}\text { Cycles-to- } \\
\text { Failure, } \\
\mathbf{N}_{\mathbf{f}}\end{array}$ & $\begin{array}{l}\text { Failure } \\
\text { Location }\end{array}$ \\
\hline 5076-A-12 & $\mathrm{DS} / \mathrm{T}$ & Simulated-Braze-Cycled & 276 & 19,300 & gauge \\
\hline $5090-01-A-6 B$ & $"$ & $"$ & 276 & 77,200 & gauge \\
\hline $5090-03-B-3 B$ & $"$ & $"$ & 241 & 38,300 & gauge \\
\hline $5077-A-11 A$ & $"$ & $"$ & 241 & 12,000 & gauge \\
\hline 5077-B-7A & $"$ & $"$ & 207 & 150,500 & gauge \\
\hline $5077-A-2$ & $"$ & $"$ & 207 & 165,400 & gauge \\
\hline $5077-\mathrm{A}-1$ & $"$ & $"$ & 138 & $>10,500,000$ & none \\
\hline $5077-A-12 B$ & $"$ & $"$ & 138 & $>10,000,000$ & none \\
\hline A1-33-1 & Equiaxed & As-Cast & 316 & 190,000 & gauge \\
\hline$A 1-36-2$ & $"$ & Simulated-Braze-Cycled & 316 & 9,500 & gauge \\
\hline
\end{tabular}


TABLE XVII

CREEP RESULTS FOR SIMULATED-BRAZE-CYCLED

DS/L NASAUT $4 \mathrm{G}-A 1$ AT $800^{\circ} \mathrm{C}$

\begin{tabular}{|c|c|c|c|c|c|c|c|}
\hline $\begin{array}{l}\text { Specimen } \\
\text { Number }\end{array}$ & $\begin{array}{l}\text { Stress } \\
\text { (MPa) }\end{array}$ & Tin & hr) $t$ & $\mathbf{C r}$ & 2.0 & $\begin{array}{c}\mathbf{t}_{\mathbf{R}} \\
(\mathbf{h r s})\end{array}$ & $\begin{array}{c}\text { Final } \\
\text { Creep Strain } \\
(\%)\end{array}$ \\
\hline $5301-6$ & 50 & 14 & - & - & - & $503.4(c)(d)$ & 0.39 \\
\hline $5076-11 B$ & 50 & 14 & 51 & - & - & $543.5(\mathrm{c})$ & 0.52 \\
\hline $5076-14 \mathrm{~T}$ & 86 & .24 & 4.5 & 15 & 47 & $66.4(c)$ & 2.61 \\
\hline $5076-14 B$ & 86 & .24 & 3.1 & 12 & 38 & $65.7(c)$ & 3.06 \\
\hline $5301-13$ & 120 & .01 & .29 & 1.2 & 2.8 & $18.8(\mathrm{~b})$ & - \\
\hline $5076-15 B$ & 120 & .03 & .30 & .91 & 2.4 & $14.0(a)$ & - \\
\hline \multicolumn{8}{|c|}{ (a) Specimen failed at time shown. Final elongation $=41.5 \%$, \% R.A. $=46.6$} \\
\hline \multicolumn{8}{|c|}{ (b) Specimen failed at time shown. Final elongation $=42.5 \%, \%$ R.A. $=64.0$} \\
\hline \multicolumn{8}{|c|}{ (c) Specimen unloaded without failure at time shown } \\
\hline \multicolumn{8}{|c|}{ (d) Specimen broke while removing from adapter } \\
\hline
\end{tabular}


TABLE XVIII

LOW-CYCLE-FATIGUE RESULTS FOR SIMULATED-BRAZE-CYCLED

NASAUT 4G-AI

\begin{tabular}{|c|c|c|c|c|}
\hline $\begin{array}{l}\text { Specimen } \\
\text { Number }\end{array}$ & Form & $\begin{array}{c}\text { Total Strain } \\
\text { Amplitude, } \frac{\Delta \epsilon_{\mathrm{T}}}{2} \\
(\%)\end{array}$ & $\begin{array}{l}\text { Cycles-to- } \\
\text { Failure, } \mathbf{N}_{\mathrm{f}}\end{array}$ & $\begin{array}{c}\text { Test } \\
\text { Temperature } \\
\left({ }^{\circ} \mathrm{C}\right)\end{array}$ \\
\hline $5301-7$ & $\overline{D S} / \mathrm{L}$ & \pm 0.10 & 41,101 & 22 \\
\hline $5301-8$ & $"$ & \pm 0.10 & $>218,300$ & 22 \\
\hline $5078-1$ & $"$ & \pm 0.15 & 26,362 & 22 \\
\hline $5078-2$ & $"$ & \pm 0.15 & 24,362 & 22 \\
\hline $5076-2$ & $"$ & \pm 0.25 & 14,539 & 22 \\
\hline $5076-3$ & $"$ & \pm 0.25 & 4,845 & 22 \\
\hline $5078-7$ & $"$ & \pm 0.30 & 44 & 22 \\
\hline $5078-12$ & $"$ & \pm 0.30 & 95 & 22 \\
\hline $5301-2$ & $"$ & \pm 0.10 & $>203,650$ & 400 \\
\hline $5078-4$ & $"$ & \pm 0.10 & $>307,900$ & 400 \\
\hline $5078-10$ & $"$ & \pm 0.15 & 35,966 & 400 \\
\hline $5301-11$ & $"$ & \pm 0.15 & $>101,560$ & 400 \\
\hline $5076-1$ & $"$ & \pm 0.30 & 3,023 & 400 \\
\hline $5301-4$ & $"$ & \pm 0.30 & 2,714 & 400 \\
\hline $5076-4$ & $"$ & \pm 0.40 & 539 & 400 \\
\hline $5301-9$ & $"$ & \pm 0.40 & 748 & 400 \\
\hline $5301-12$ & $"$ & \pm 0.15 & $>337,300$ & 800 \\
\hline $5301-14$ & $"$ & \pm 0.15 & $>262,295$ & 800 \\
\hline $5301-3$ & $"$ & \pm 0.30 & 1,599 & 800 \\
\hline $5301-10$ & $"$ & \pm 0.30 & 6,092 & 800 \\
\hline $5078-3$ & $"$ & \pm 0.40 & 1,166 & 800 \\
\hline $5078-5$ & $"$ & \pm 0.40 & 1,390 & 800 \\
\hline 5078-9 & $"$ & \pm 0.50 & 473 & 800 \\
\hline $5078-11$ & $"$ & \pm 0.50 & 392 & 800 \\
\hline A1-24-1 & Equiaxed & \pm 0.40 & 100 & 22 \\
\hline A1-42-1 & $"$ & \pm 0.40 & 429 & 400 \\
\hline A $1-40-1$ & $"$ & \pm 0.20 & 2,959 & 800 \\
\hline A1-39-1 & $"$ & \pm 0.40 & 905 & 800 \\
\hline
\end{tabular}


TABLE XIX

HIGH-CYCLE-FATIGUE FOR SIMULATED-BRAZE-CYCLED

DS/L NASAUT 4G-AI

\begin{tabular}{|c|c|c|c|}
\hline $\begin{array}{l}\text { Specimen } \\
\text { Number }\end{array}$ & $\begin{array}{c}\sigma_{\max } \\
(\mathrm{MPa})\end{array}$ & $\begin{array}{l}\text { Cycles-to- } \\
\text { Failure, } \mathbf{N}_{\mathrm{f}}\end{array}$ & $\begin{array}{c}\text { Test Temperature } \\
\left({ }^{\circ} \mathrm{C}\right)\end{array}$ \\
\hline 5301-17 & 241 & 141,632 & 22 \\
\hline $5301-31$ & 241 & $>10,475,000$ & 22 \\
\hline 5301-24 & 264 & $>10,000,000$ & 22 \\
\hline $5301-25$ & 264 & $>10,000,000$ & 22 \\
\hline $5301-22$ & 287 & 86,952 & 22 \\
\hline 5301-15 & 287 & 167,170 & 22 \\
\hline $5301-20$ & 310 & 995,708 & 22 \\
\hline $5301-34$ & 310 & 114,856 & 22 \\
\hline $5301-27$ & 241 & $>10,039,804$ & 400 \\
\hline $5301-25 B$ & 241 & $>10,000,200$ & 400 \\
\hline $5076-12 \mathrm{~T}$ & 287 & $>10,221,000$ & 400 \\
\hline $5301-29$ & 287 & $>11,211,000$ & 400 \\
\hline $5301-23$ & 310 & $>10,000,009$ & 400 \\
\hline $5301-33 A$ & 310 & 177,822 & 400 \\
\hline $5076-15 T$ & 310 & $>10,000,000$ & 400 \\
\hline $5301-25 B^{*}$ & 333 & 73,652 & 400 \\
\hline $5301-29 * *$ & 360 & 38,307 & 400 \\
\hline $5301-18^{* * *}$ & 376.5 & $7,406,593$ & 400 \\
\hline $5301-26$ & 241 & 41,397 & 800 \\
\hline $5076-11 B$ & 241 & 141,800 & 800 \\
\hline $5301-16$ & 264 & 17,251 & 800 \\
\hline $5301-19$ & 264 & 42,732 & 800 \\
\hline 5076-10B & 287 & 15,323 & 800 \\
\hline $5076-11 \mathrm{~T}$ & 287 & 13,423 & 800 \\
\hline $5301-33 B$ & 310 & 4,635 & 800 \\
\hline $5301-20-2$ & 310 & 5,042 & 800 \\
\hline \multicolumn{4}{|c|}{ * $\quad$ Reloaded following $>10,000,200$ cycles at $241 \mathrm{MPa}$ and $400^{\circ} \mathrm{C}$} \\
\hline \multicolumn{4}{|c|}{ Reloaded following $>11,211,000$ cycles at $287 \mathrm{MPa}$ abnd $400^{\circ} \mathrm{C}$} \\
\hline \multicolumn{4}{|c|}{ Reloaded following $>3,162,414$ cycles at $360 \mathrm{MPa}$ and $400^{\circ} \mathrm{C}$} \\
\hline
\end{tabular}


TABLE XX

TENSILE PROPERTIES OF SIMULATED-BRAZE-CYCLED, DS/L NASAUT 4G-A1

\begin{tabular}{|c|c|c|c|c|c|c|}
\hline $\begin{array}{c}\text { Specimen } \\
\text { Identification }\end{array}$ & $\begin{array}{l}\text { Test } \\
\text { Temp. } \\
\left({ }^{\circ} \mathbf{C}\right)\end{array}$ & $\begin{array}{c}\text { Elastic } \\
\text { Modulus } \\
\text { (GPa) }\end{array}$ & $\begin{array}{c}\text { Ultimate } \\
\text { Tensile } \\
\text { Stress } \\
\text { (MPa) }\end{array}$ & $\begin{array}{c}0.2 \% \text { Offset } \\
\text { Yield Stress } \\
(\mathrm{MPa})\end{array}$ & $\begin{array}{c}\text { Strain-to- } \\
\text { Failure } \\
(\%)\end{array}$ & $\begin{array}{c}\text { Reduction- } \\
\text { in-Area } \\
(\%)\end{array}$ \\
\hline 5076-13T & 22 & 131.6 & 507 & 369 & 1.0 & 1.1 \\
\hline $5301-32$ & 22 & 135.7 & 617 & 514 & 0.8 & 0 \\
\hline $5076-17 \mathrm{~T}^{*}$ & 200 & 113.0 & 395 & 338 & 0.8 & 0 \\
\hline $5076-18 \mathrm{~T}^{*}$ & 200 & 128.2 & 411 & 320 & 0.7 & 0.8 \\
\hline $5076-12 B$ & 400 & 113.0 & 451 & 328 & 1.6 & 0.6 \\
\hline 5076-13B & 400 & 112.3 & 447 & 336 & 1.5 & 0.6 \\
\hline $5078-6^{*}$ & 600 & 92.3 & 410 & 294 & 1.6 & 1.0 \\
\hline $5301-1^{*}$ & 600 & 115.8 & 451 & 280 & 3.1 & 2.1 \\
\hline 5078-8* & 800 & 73.7 & 240 & 186 & 29.8 & 37.3 \\
\hline $5301-5^{*}$ & 800 & 76.5 & 268 & 192 & 19.3 & 27.1 \\
\hline
\end{tabular}




\section{Fe-Mn-Cr-AI-C ALLOY ITERATION FLOW CHART}

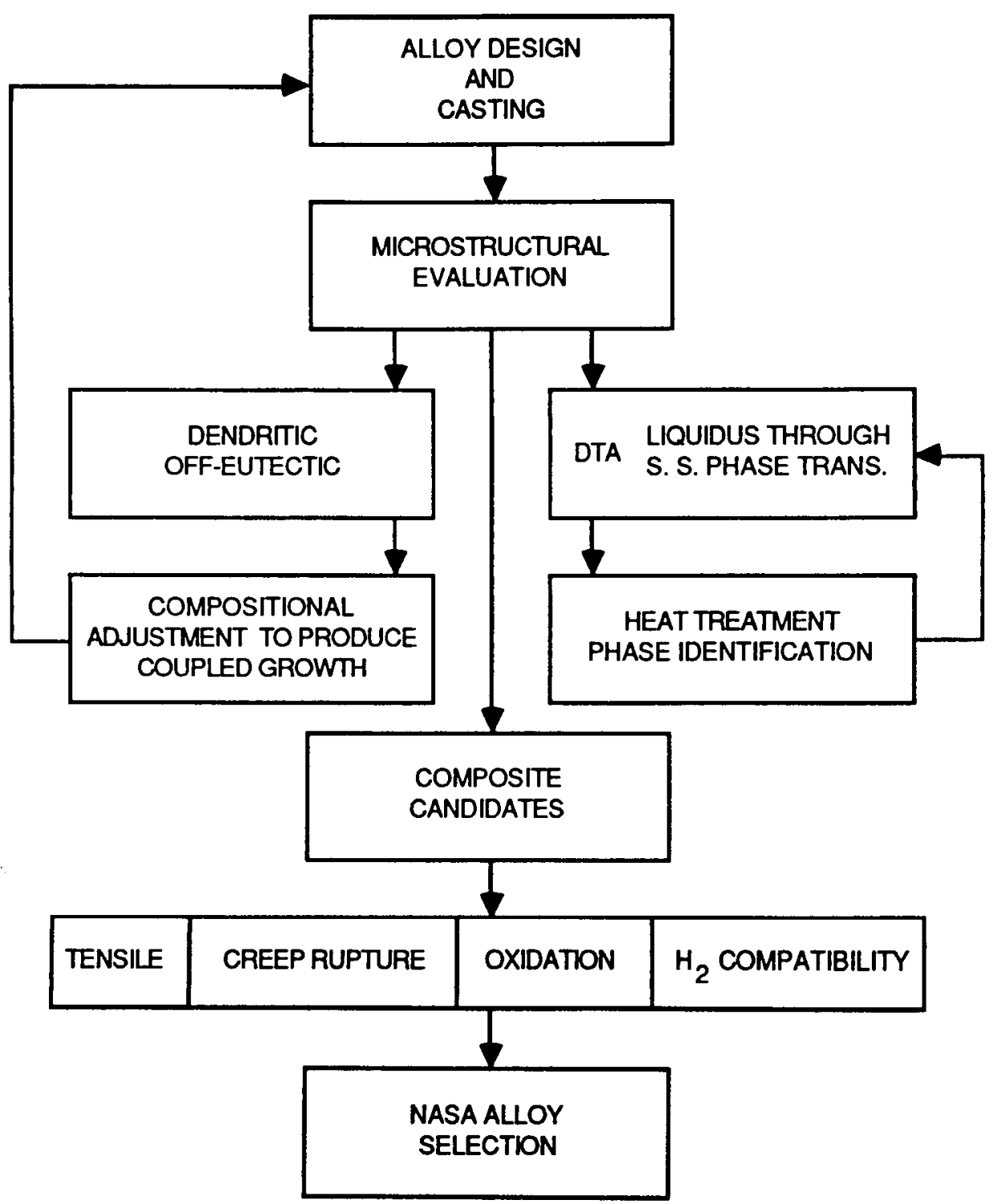


FIG. 2

\section{LARSON-MILLER RUPTURE CURVES FOR NASAUT 4G MODIFICATIONS}

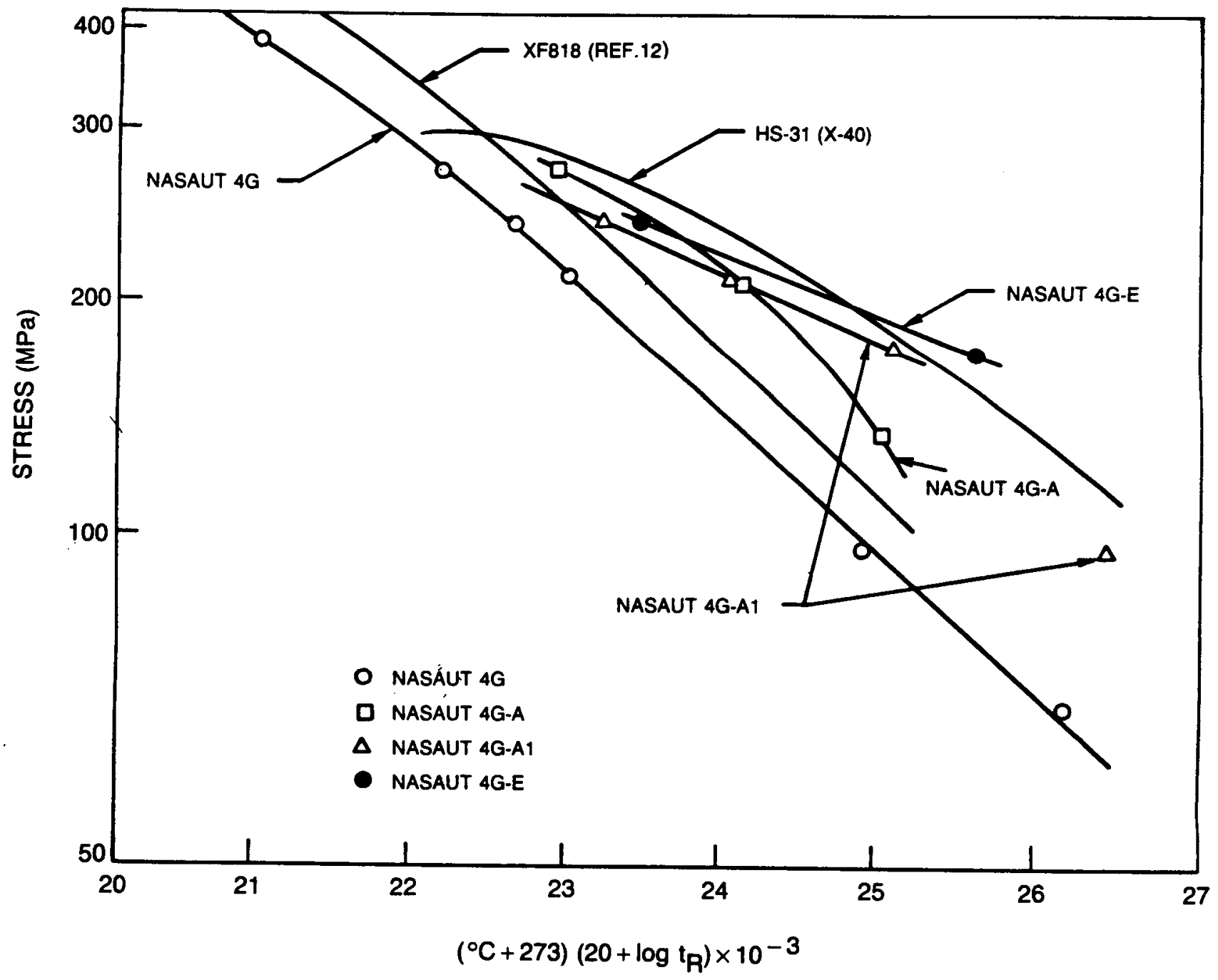




\section{OF POOR QUALITY}

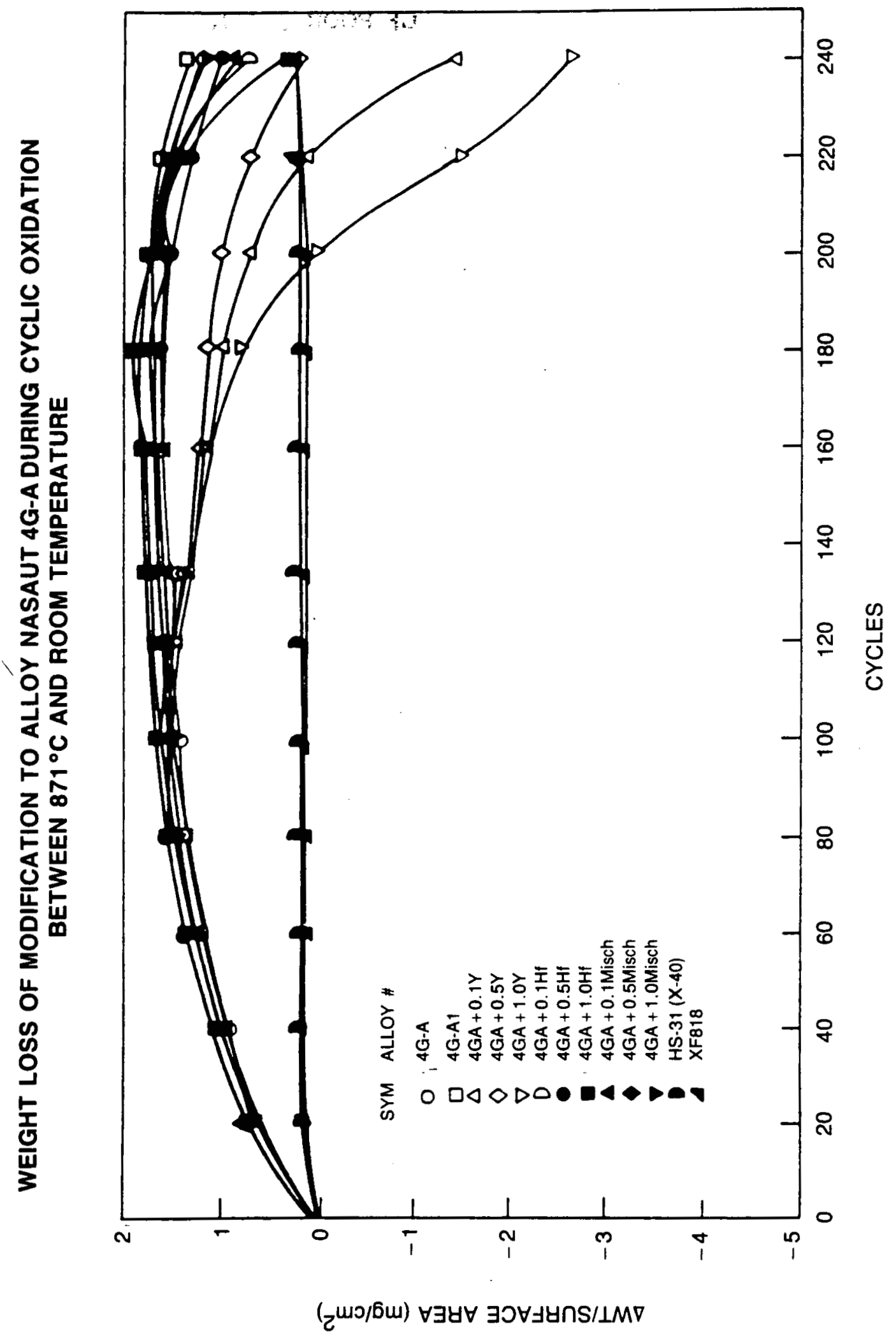




\section{GASEOUS OXIDATION TESTING OF FERROUS/COBALT STIRLING ENGINE HEATER HEAD ALLOYS}

(AFTER 383 HOURS AT $871^{\circ} \mathrm{C}$ WITH 35ppm NaCl$(g)$ IN AIR)
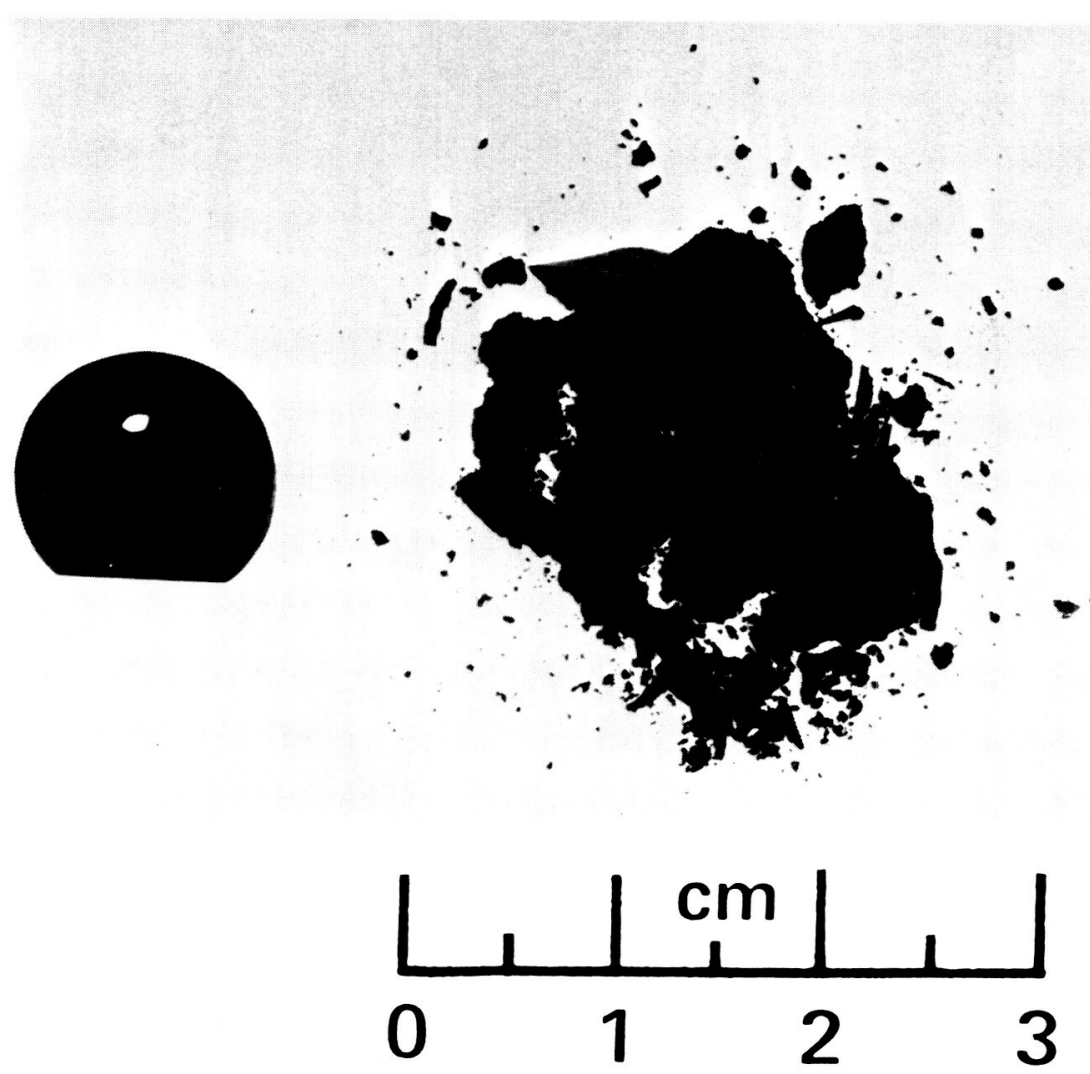

HS-31 (X-40)

XF 818

NASAUT 4G-A1 
FIG. 5

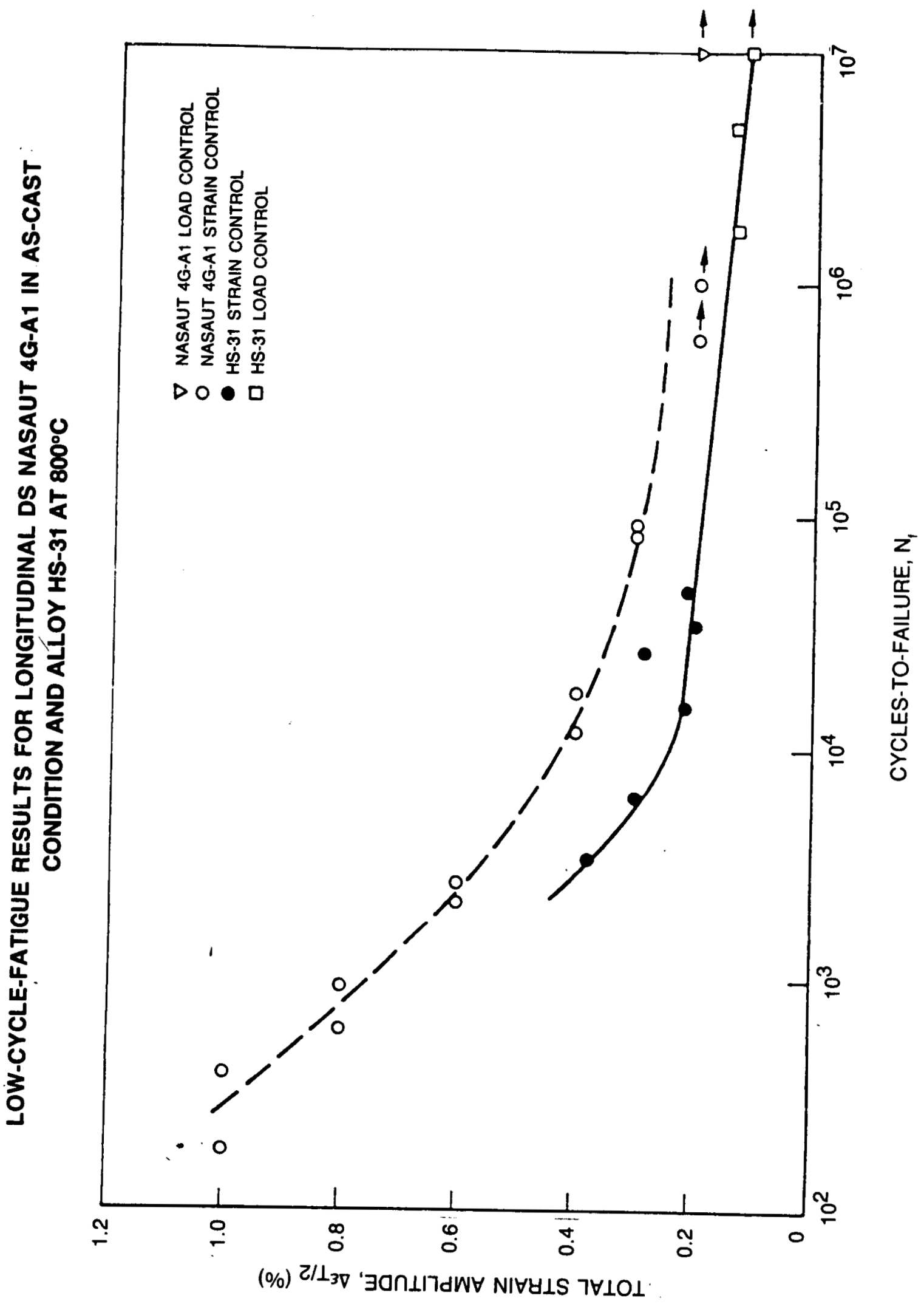



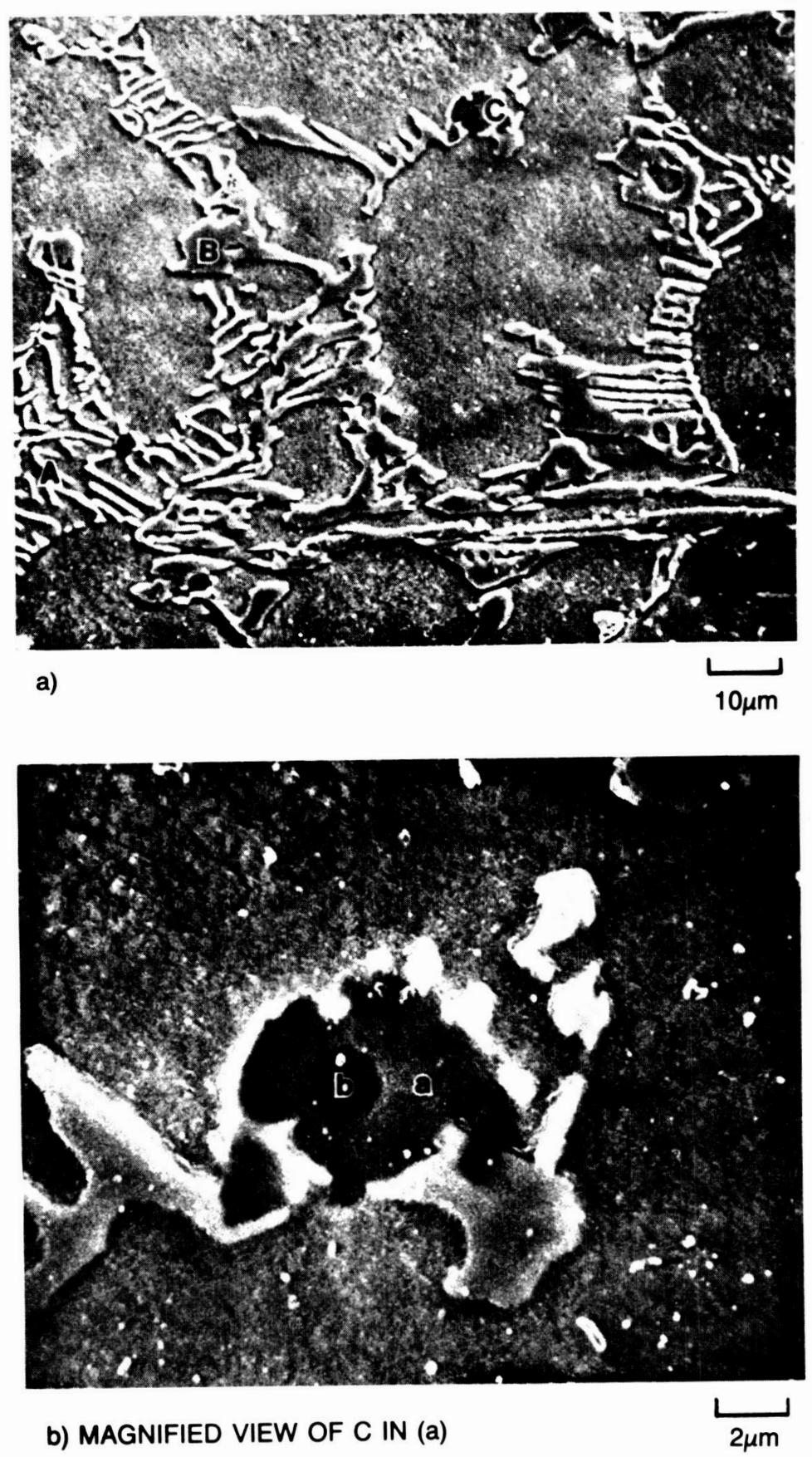


\section{AGE-HARDENING RESPONSE FOR ALLOY NASAUT 4G-A1}

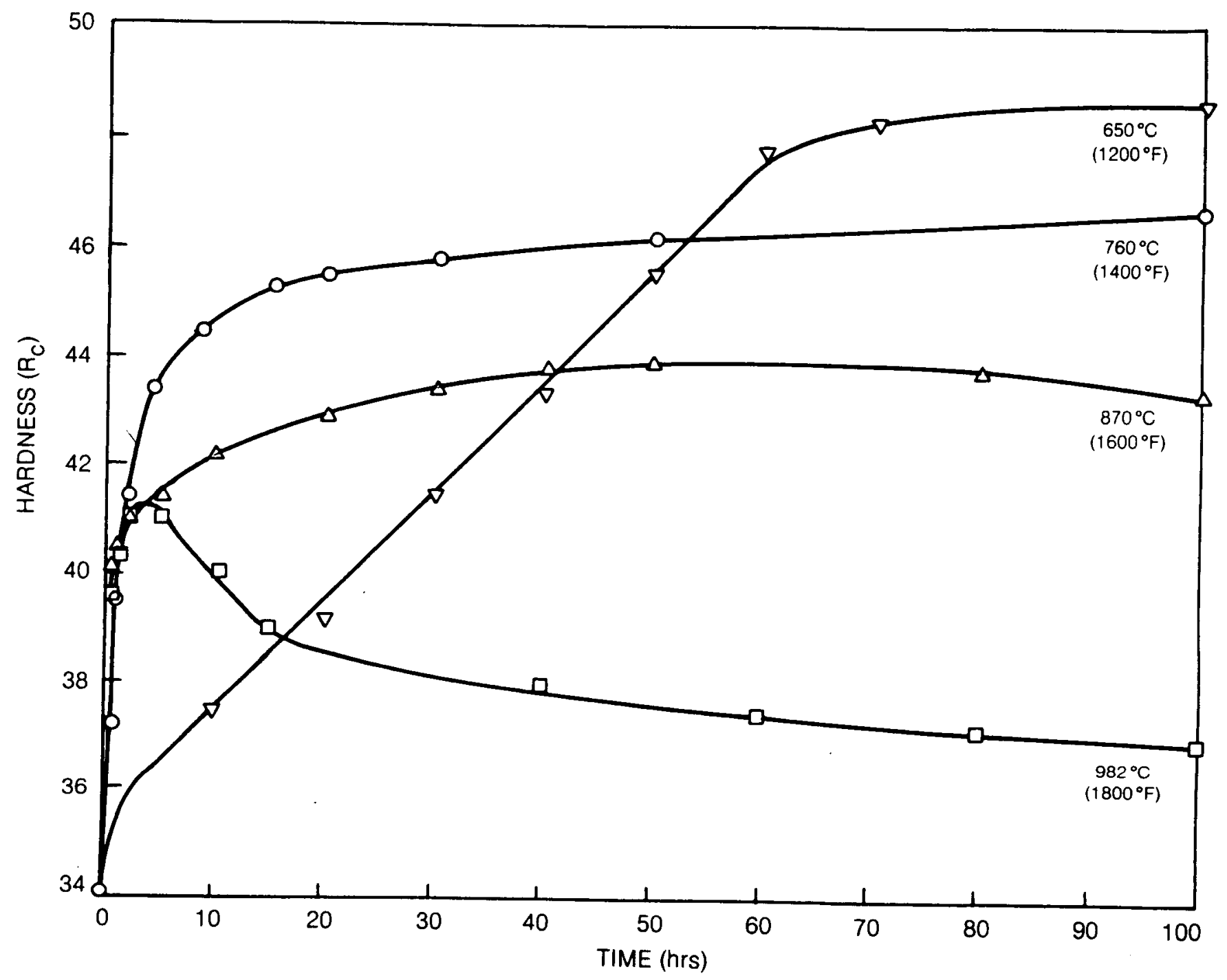




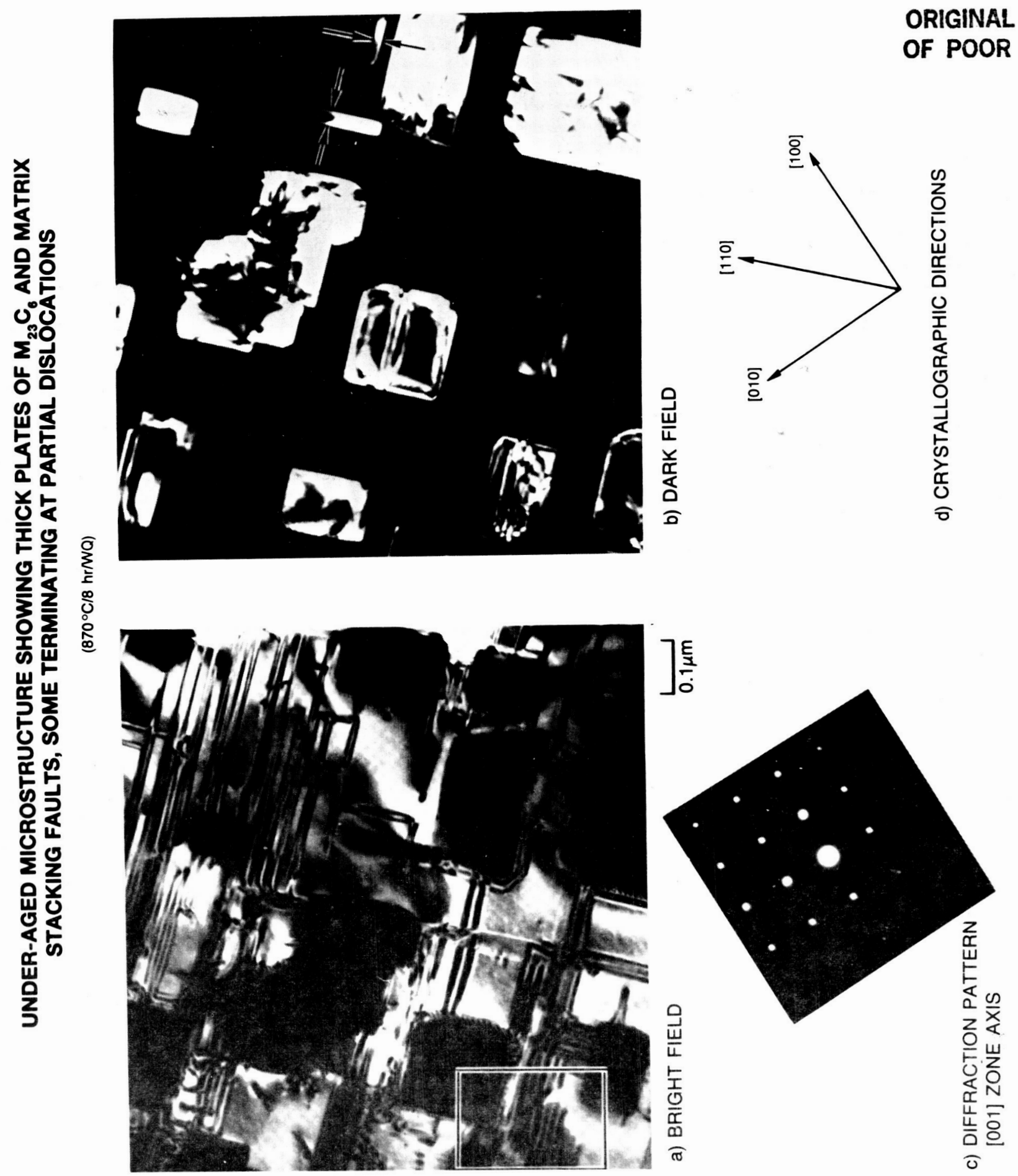




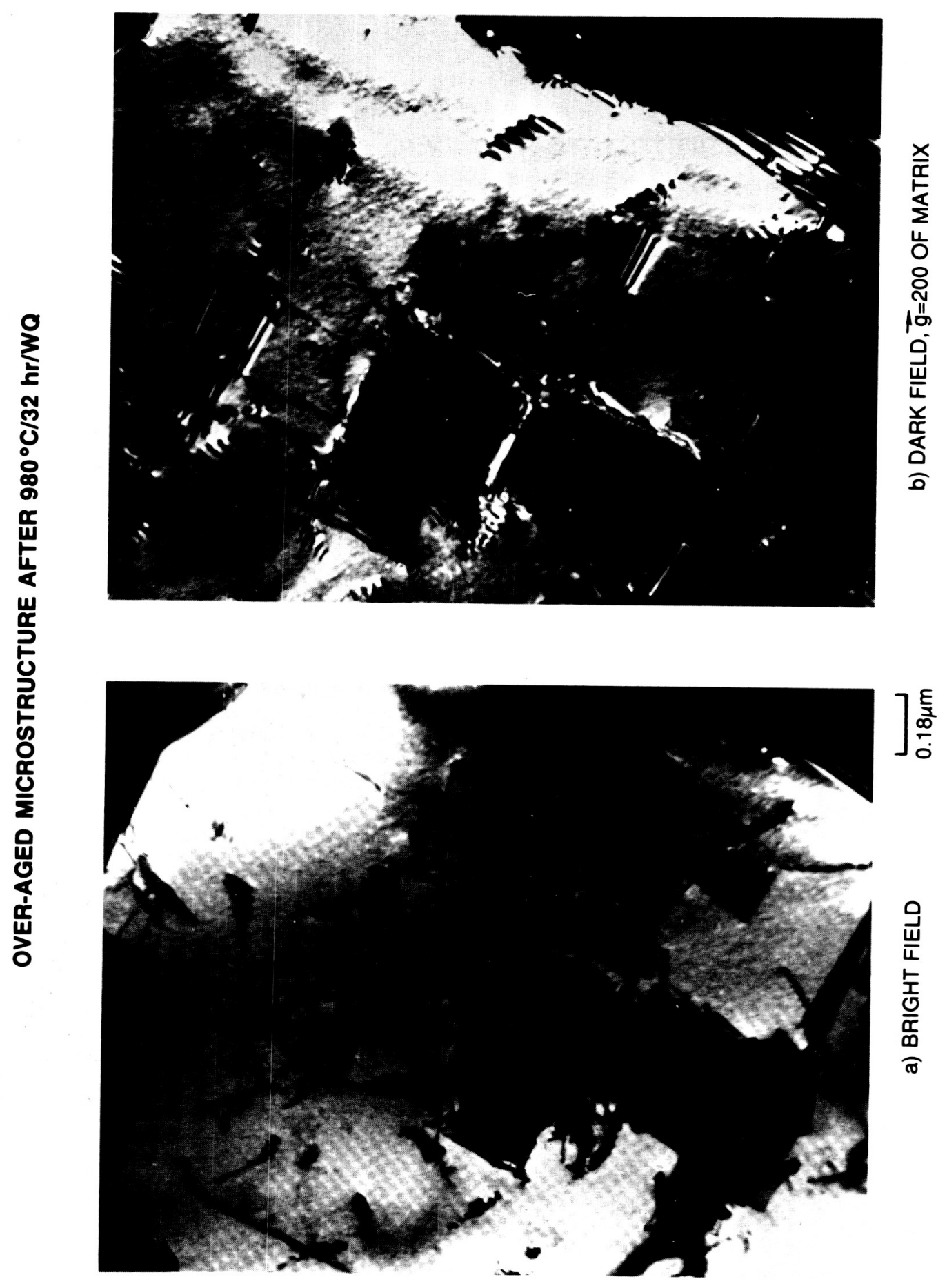




\section{EFFECT OF HEAT TREATMENT ON YIELD STRESS FOR NASAUT 4G-A1}

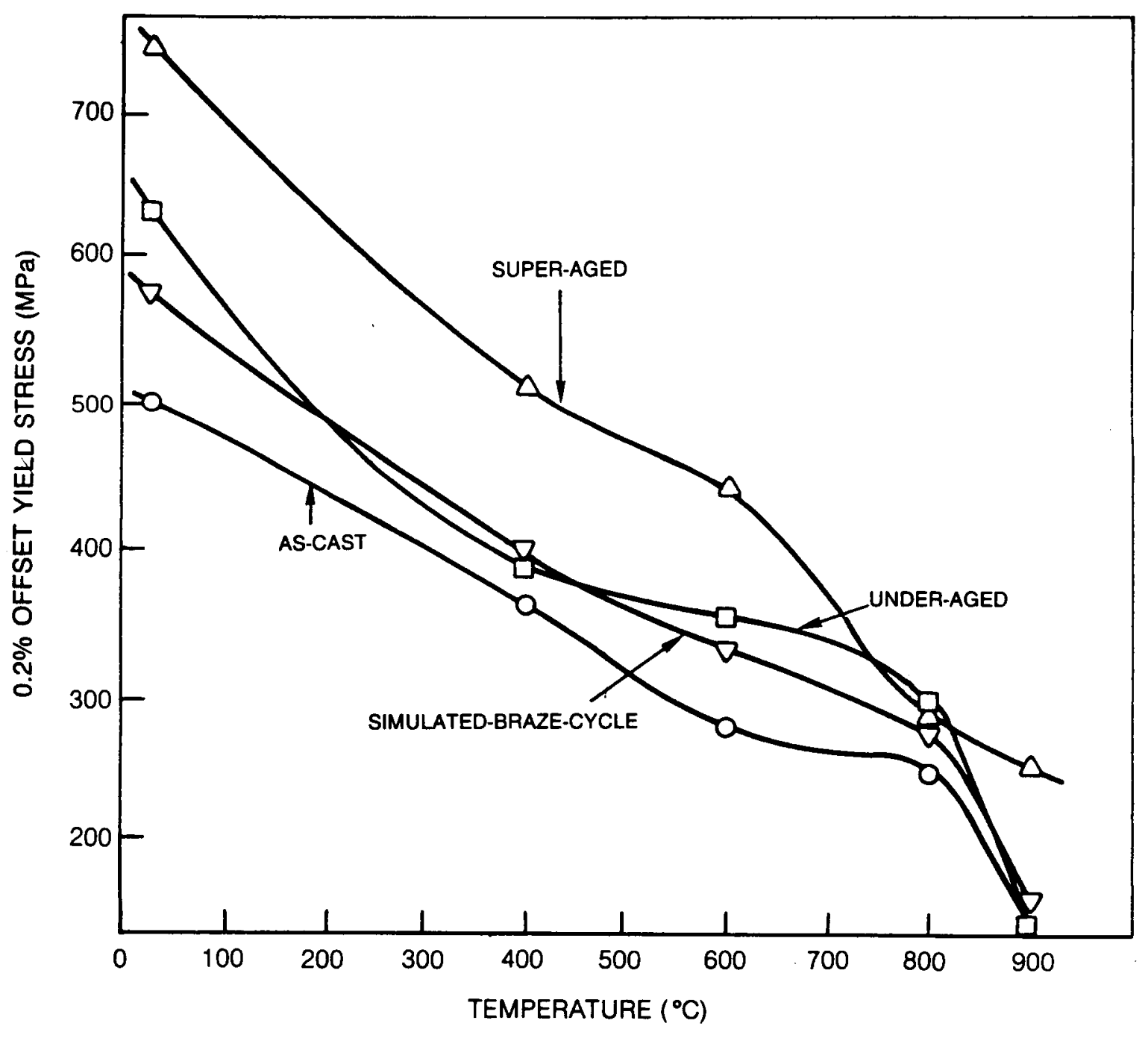




\section{EFFECT OF HEAT TREATMENT ON STRAIN-TO-FAILURE FOR NASAUT 4G-A1}

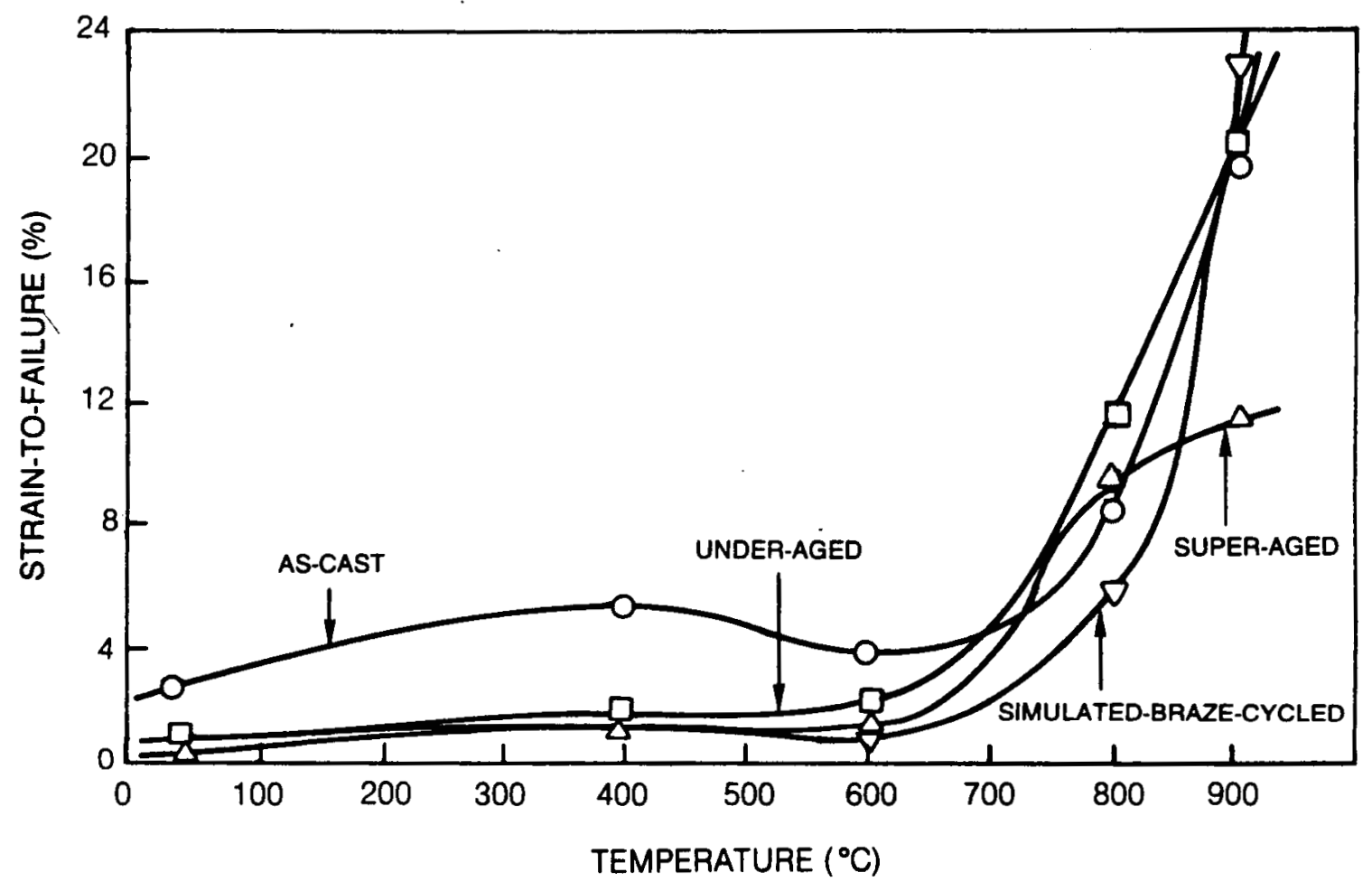




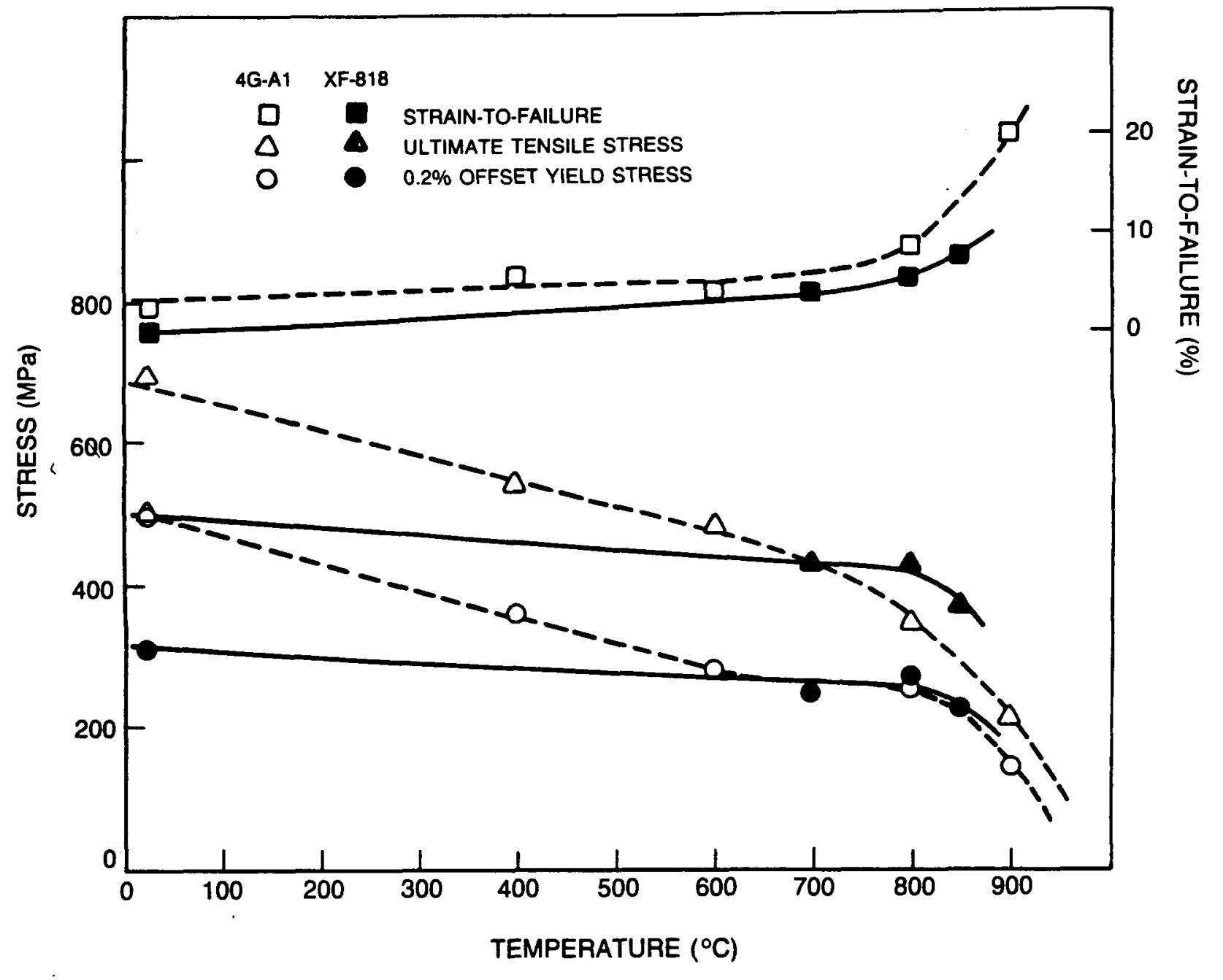




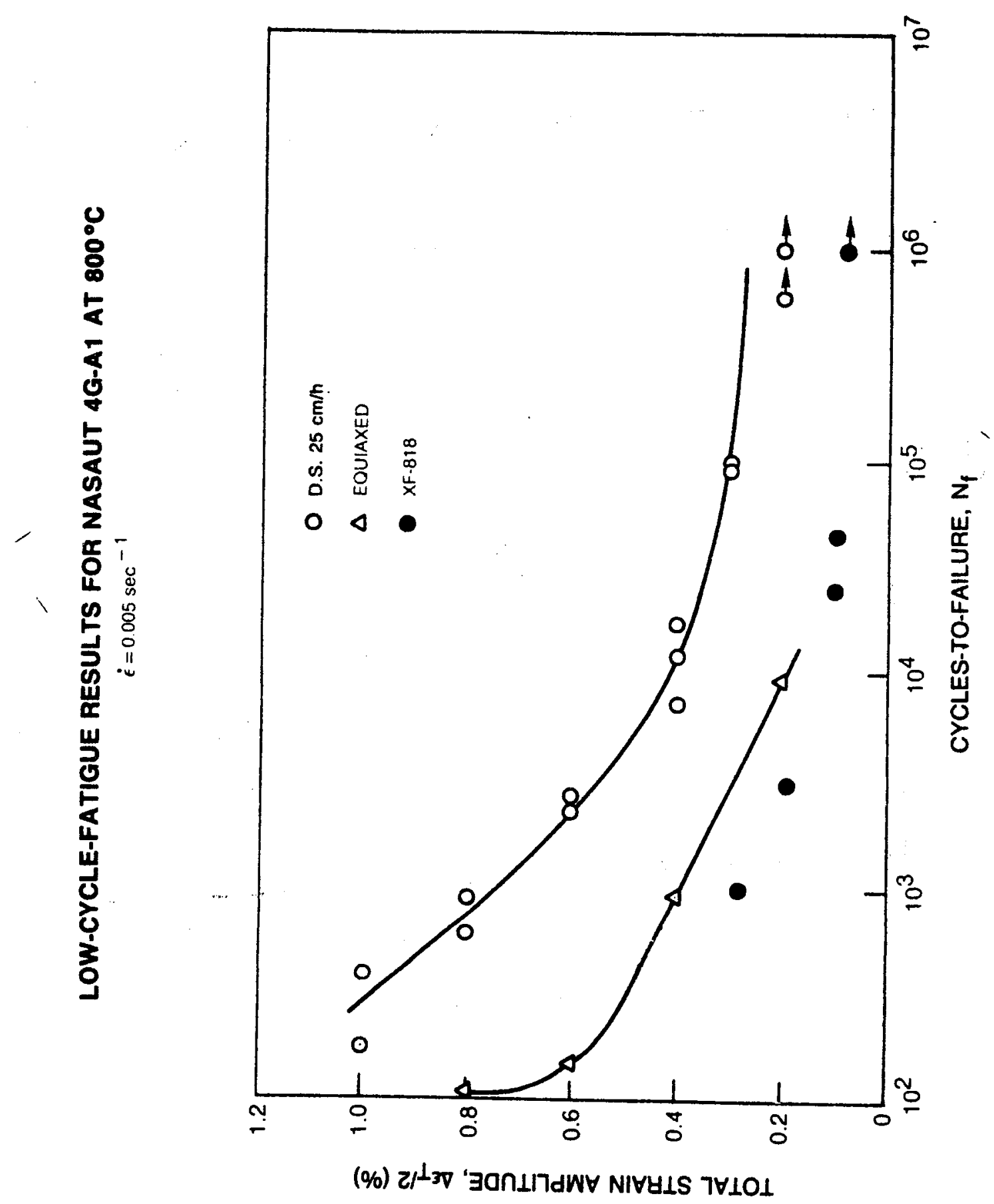




\section{LOW-CYCLE FATIGUE OF NASAUT 4G-A1 EQUIAXED CASTINGS TESTED AT $800^{\circ} \mathrm{C}$}

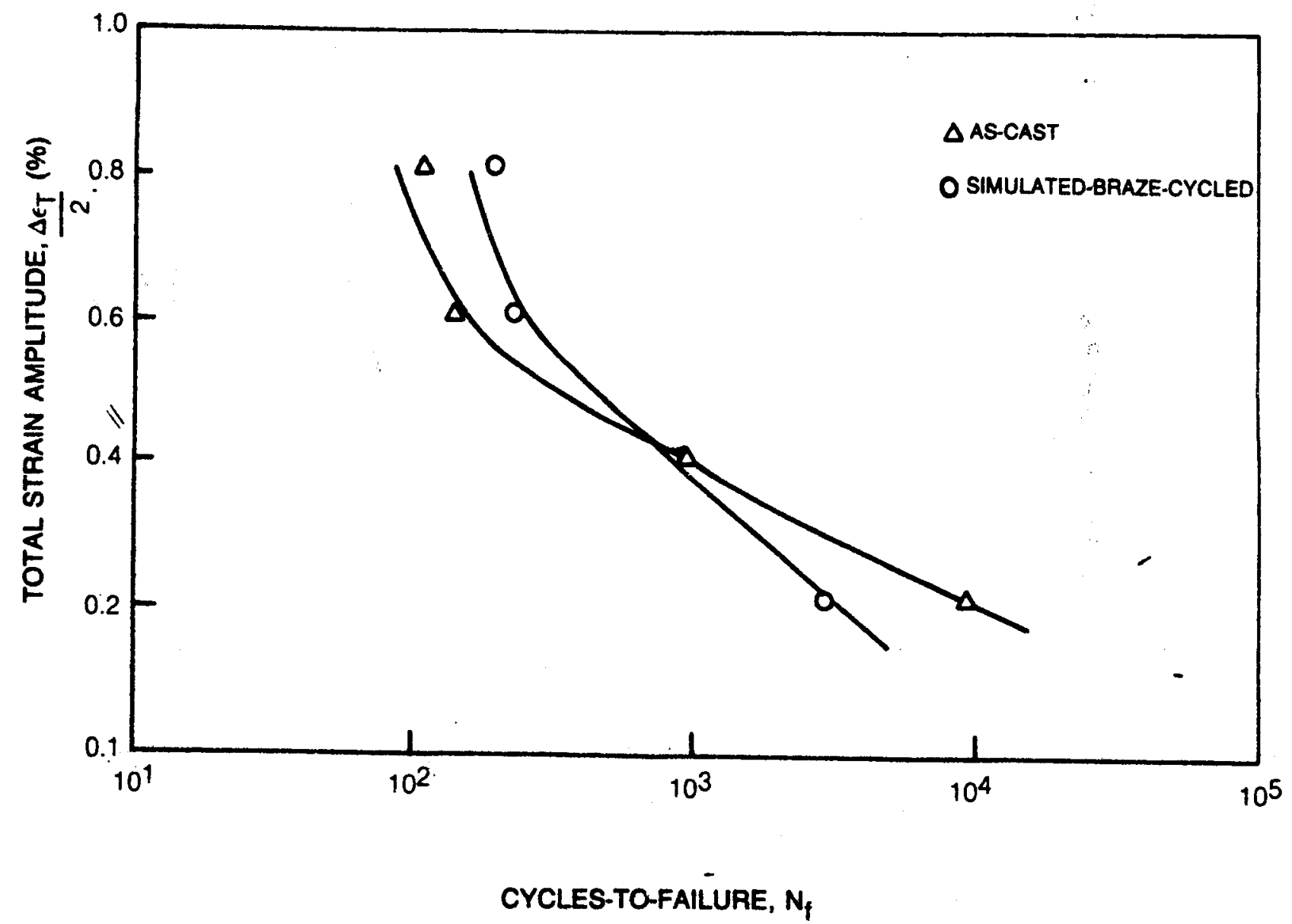




\section{LOW-CYCLE FATIGUE OF NASAUT 4G-A1 EQUIAXED CASTINGS}

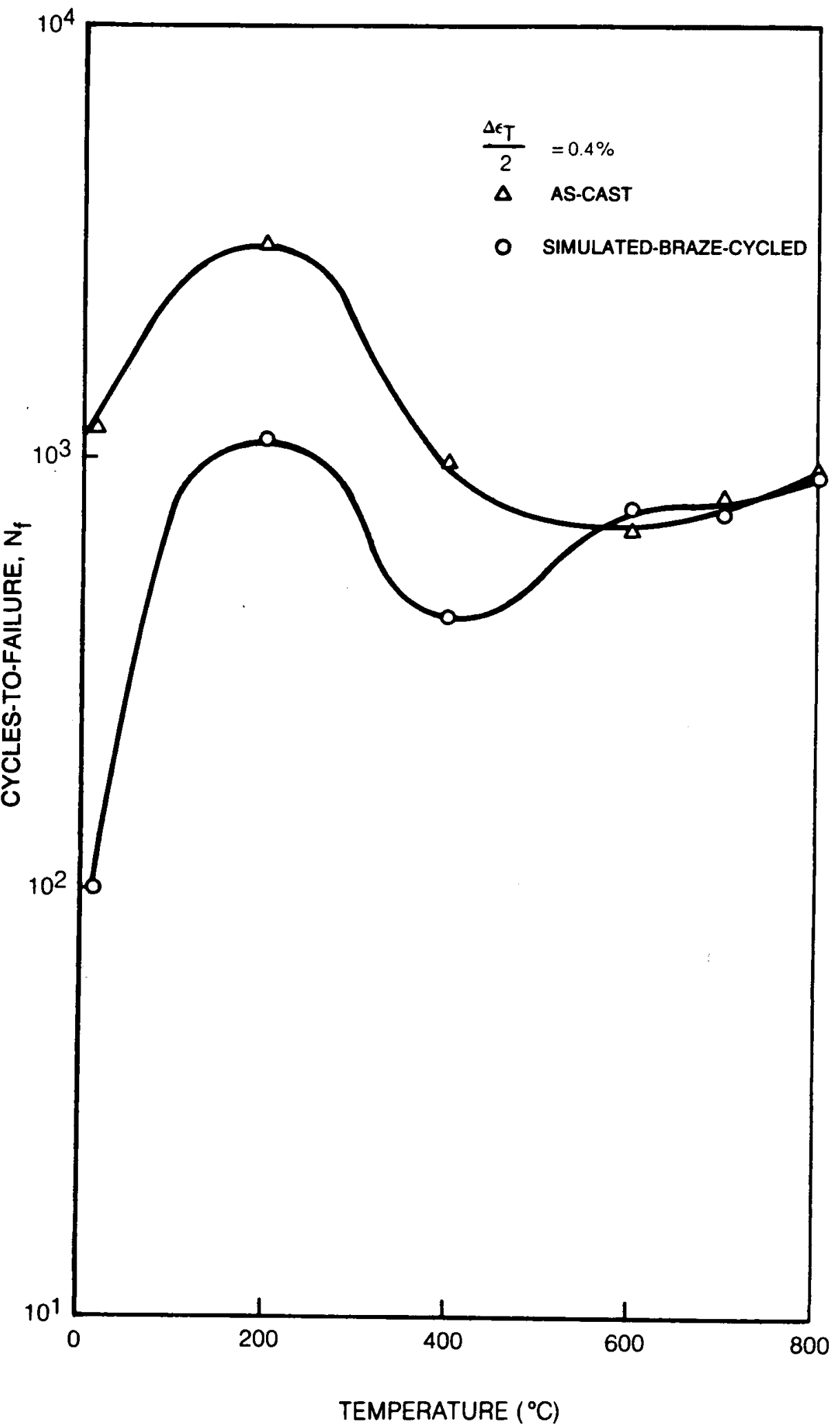


FIG. 16

LOW-CYCLE FATIGUE OF SIMULATED-BRAZE-CYCLED, EQUIAXED NASAUT 4G-A1

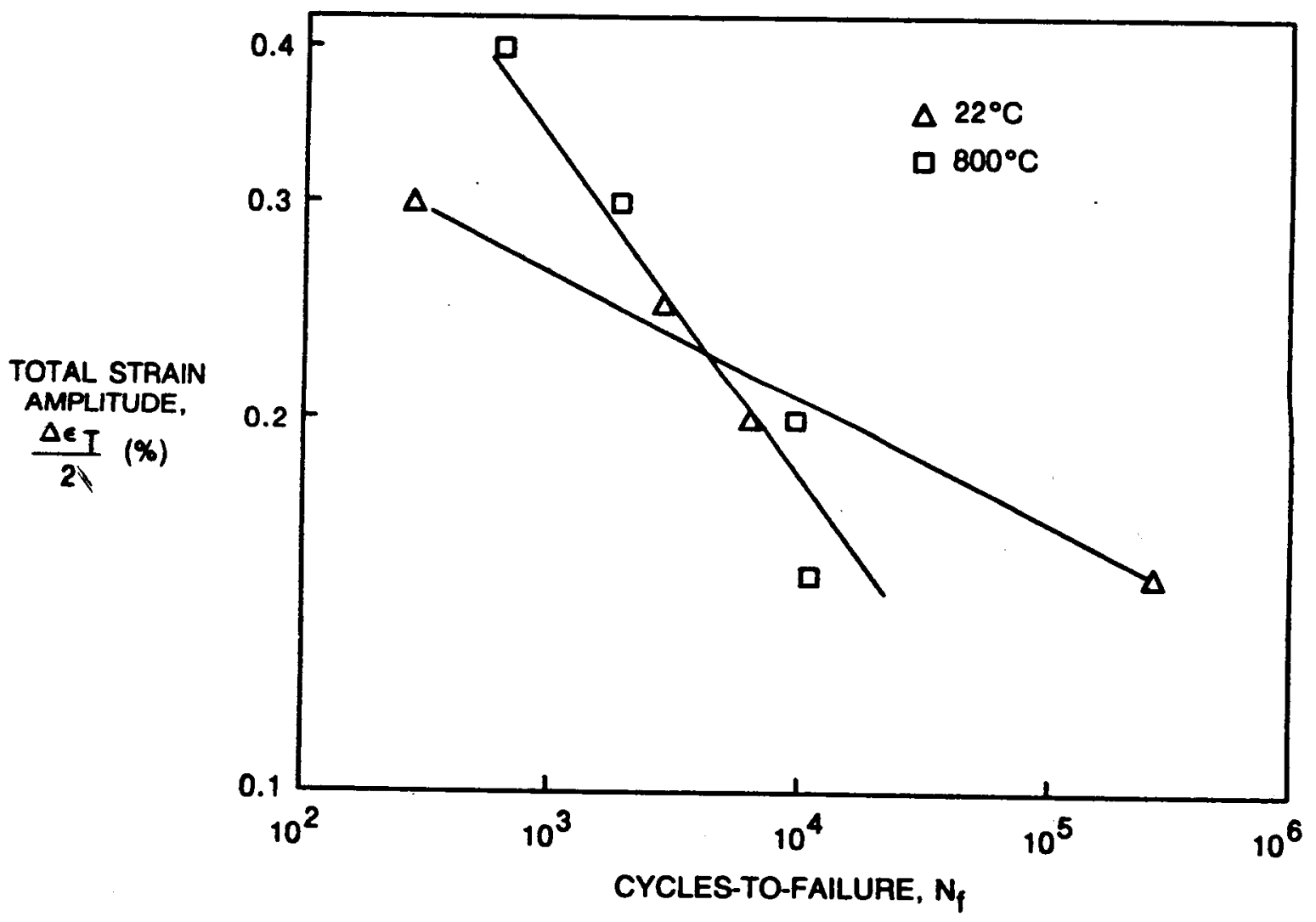




\section{HIGH-CYCLE FATIGUE OF VARIOUSLY HEAT-TREATED NASAUT 4G-A1 AT $800^{\circ} \mathrm{C}$}

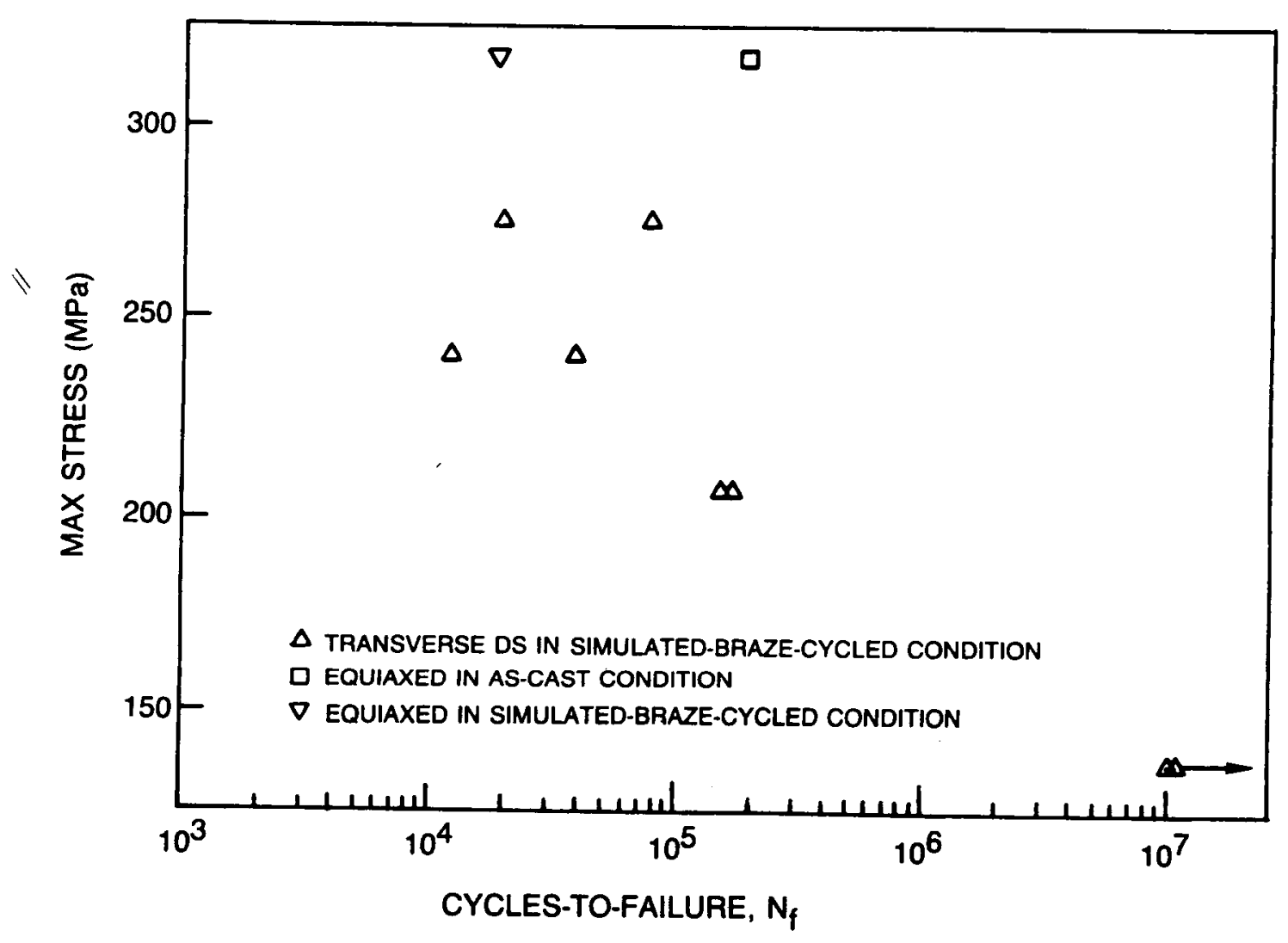


ORIGINAL PAGE

BLACK AND WHITE PHOTOGRAPH

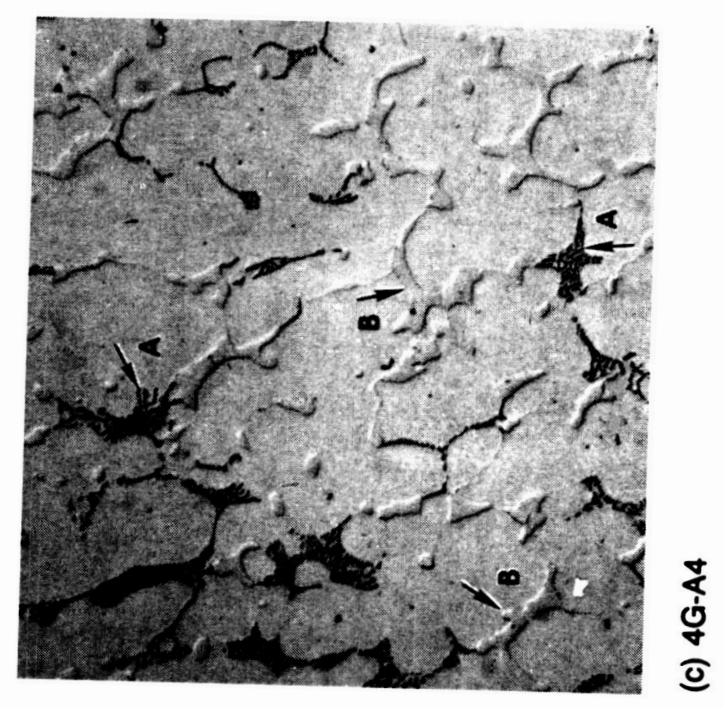

FIG. 18
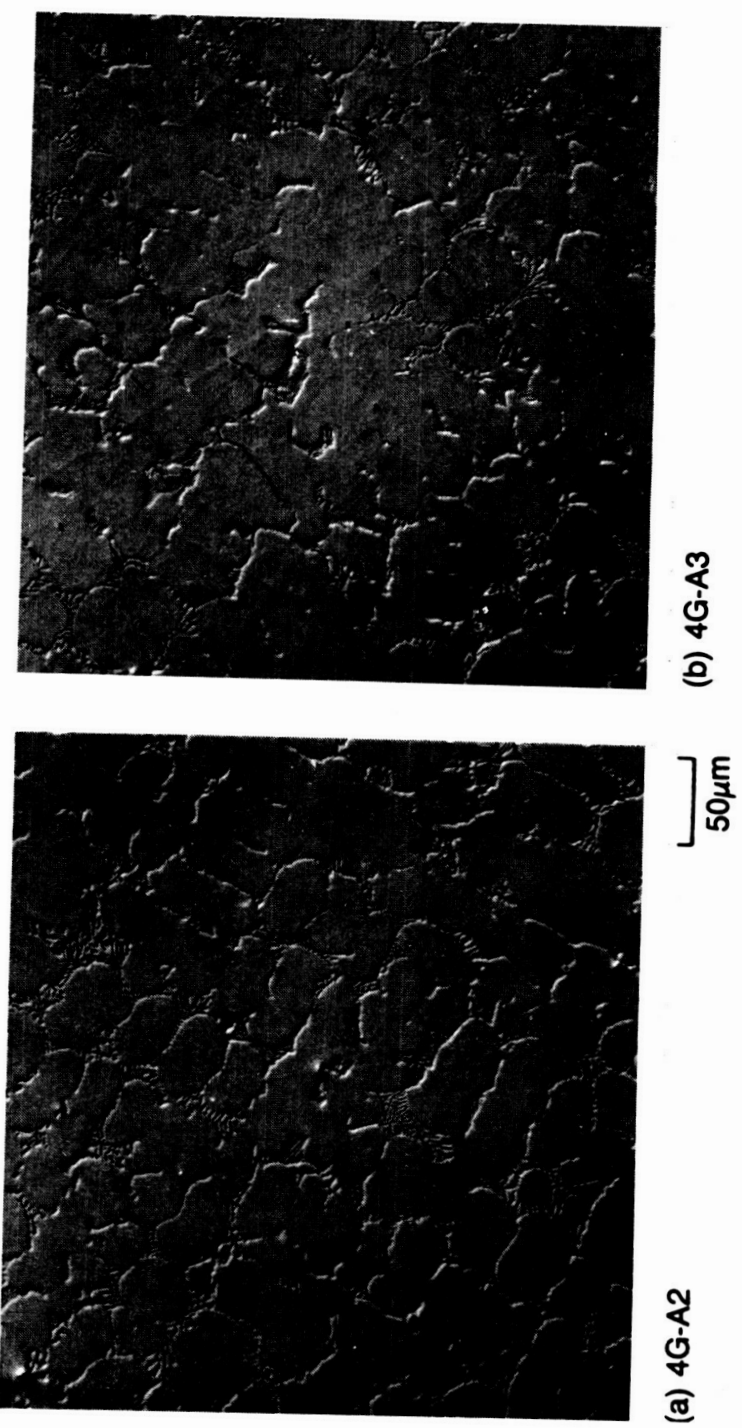

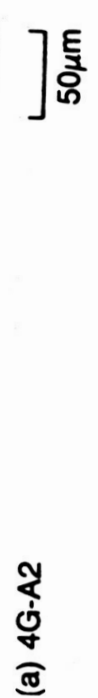

$86-5-5-1$ ORIGINAL PAGE IS OF POOR QUALITY 
ORIGINAL PAGE

BLACK AND WHITE PHOTOGRAPH
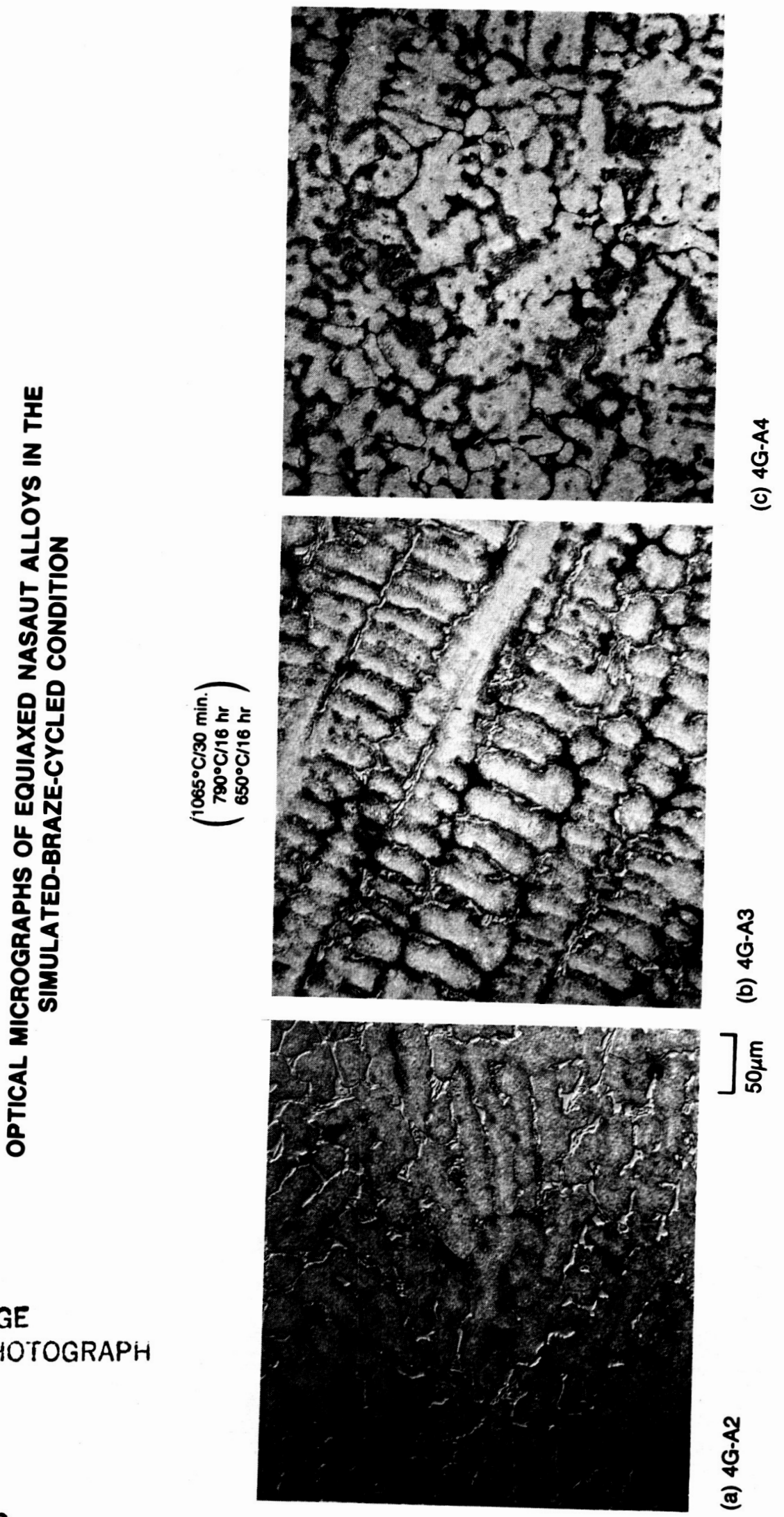

FIG. 19

OF POOR QUALITY

$86-5-5-2$ 
STRAIN-TO-FAILURE, $\varepsilon_{f}(\%)$

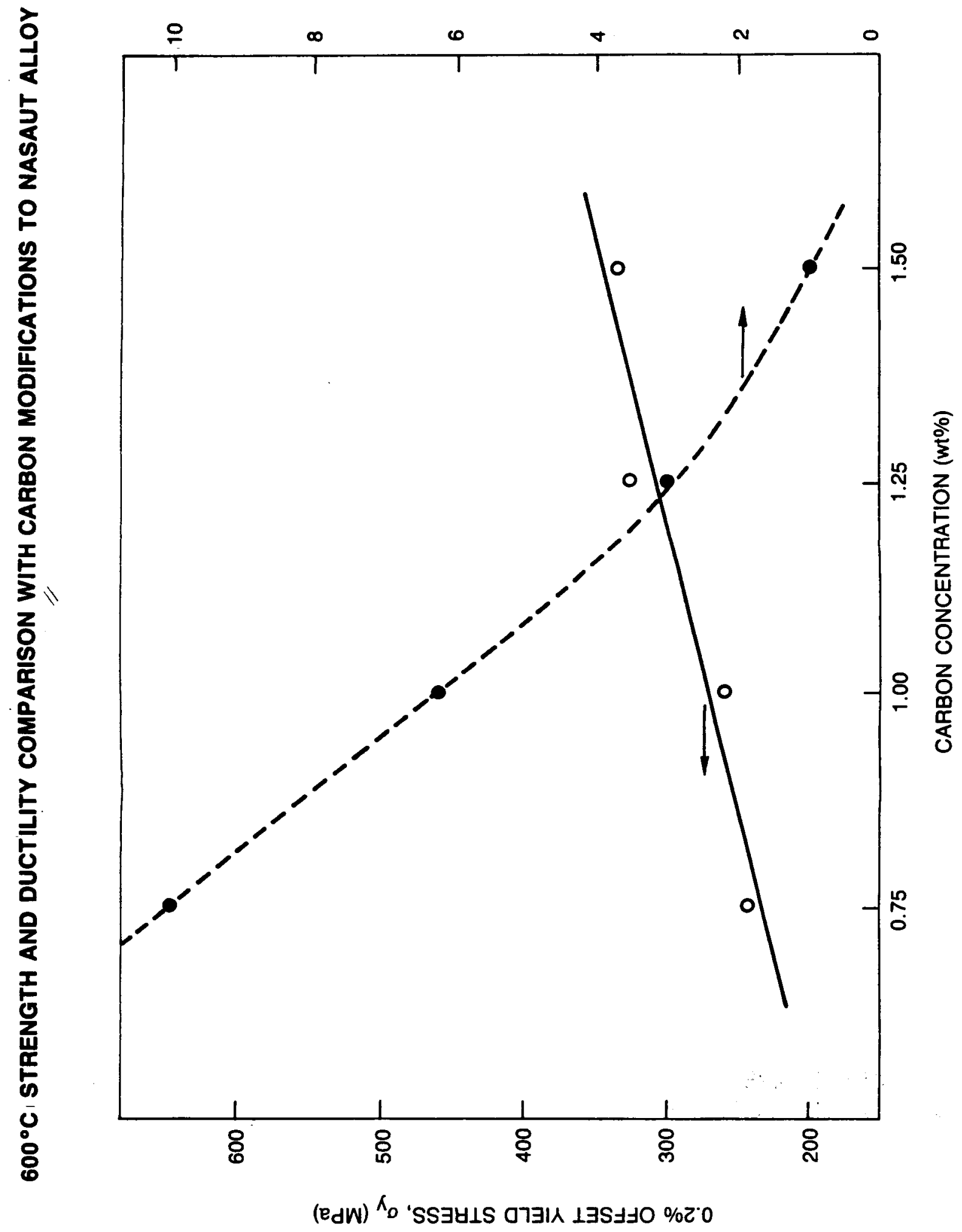




\section{$800^{\circ} \mathrm{C}$ LOW-CYCLE-FATIGUE DATA FOR SIMULATED-BRAZE-CYCLED CARBON} MODIFIED ALLOYS

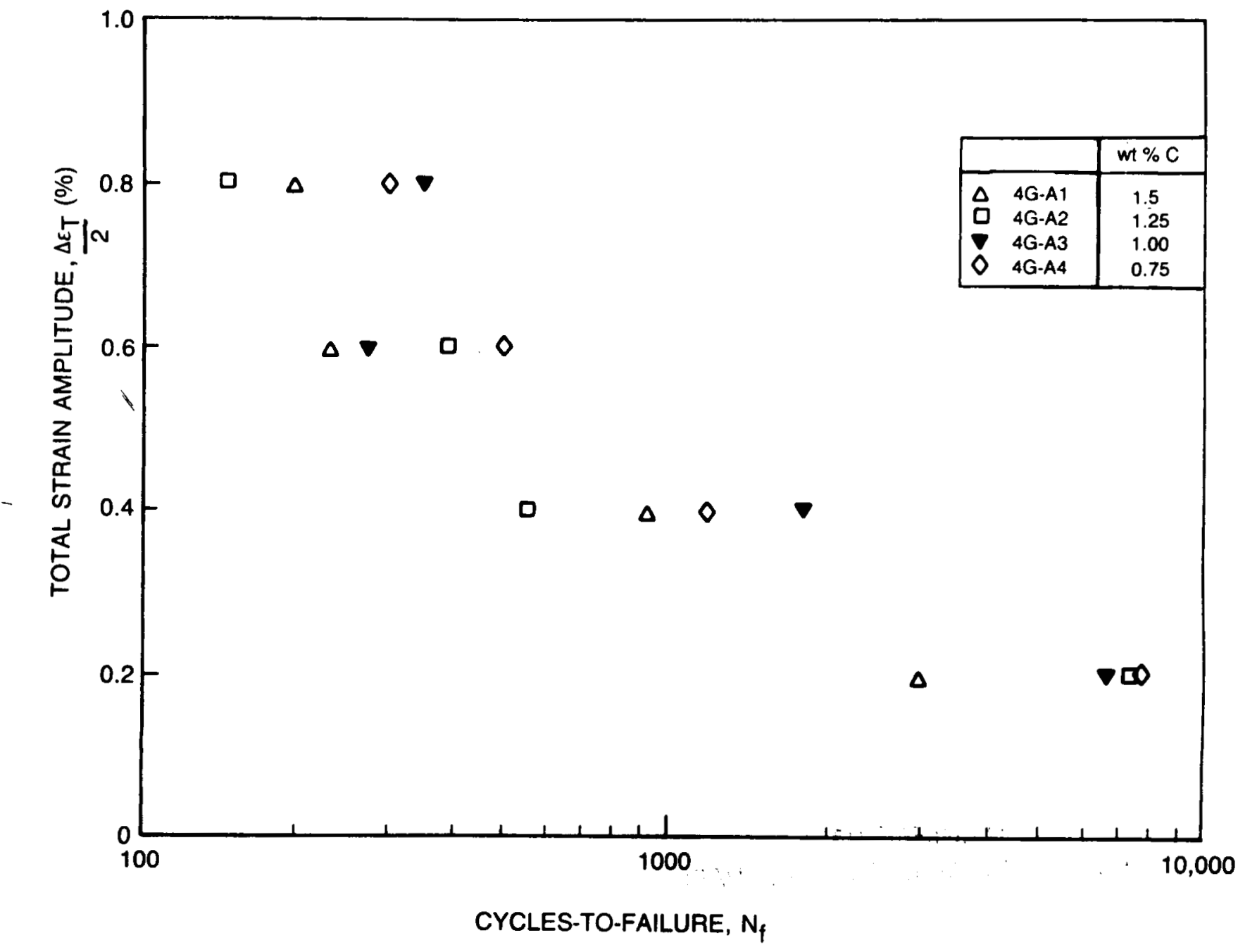

$\because \because 3$. 


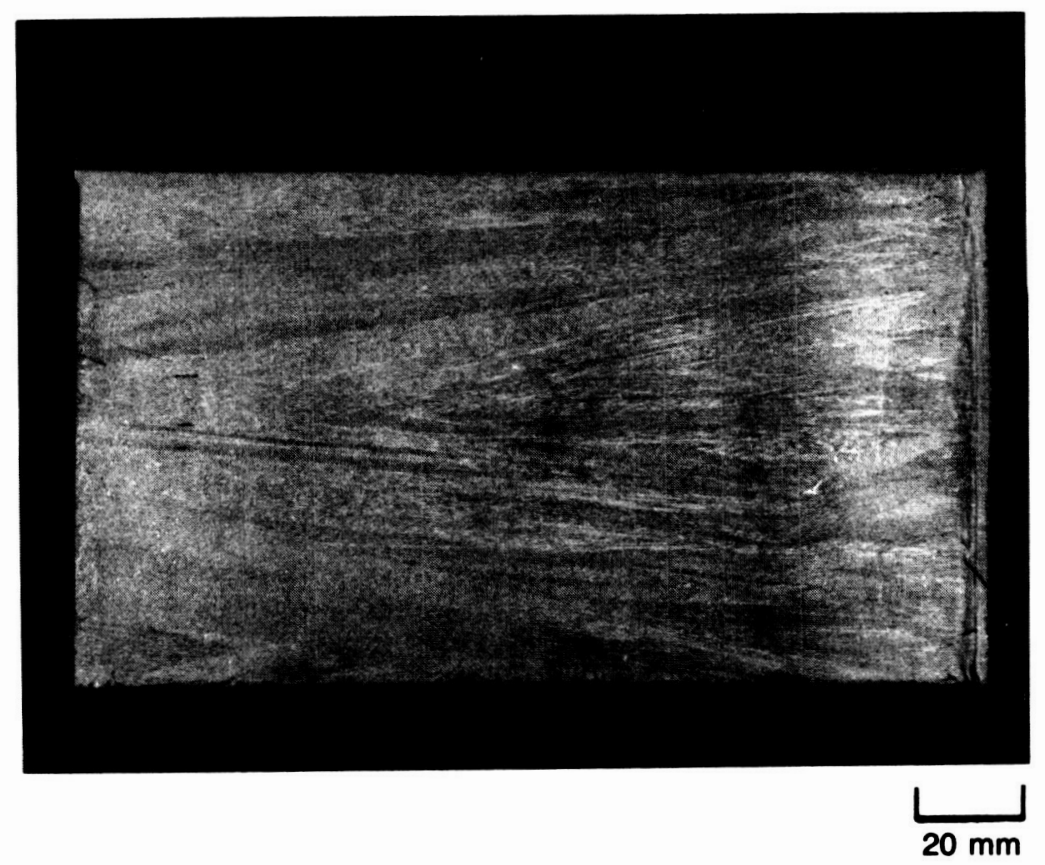

ORIGINAL PAGE

BLACK AND WHITE PHOTOGRAPH

ORIGINAL PAGE IS

OF POOR QUALITY 
ORIGINAL PAGE
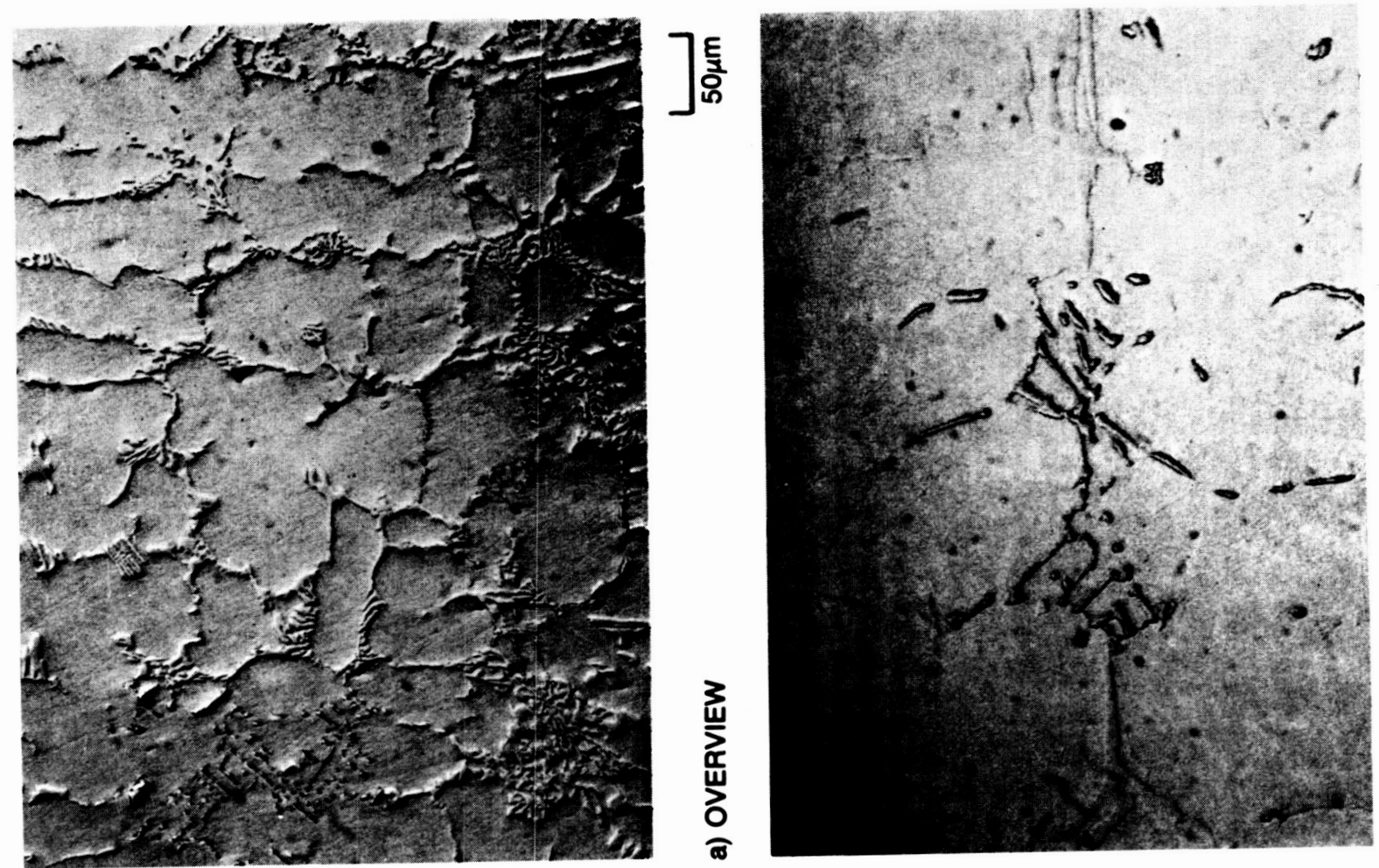

] 통

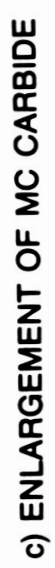
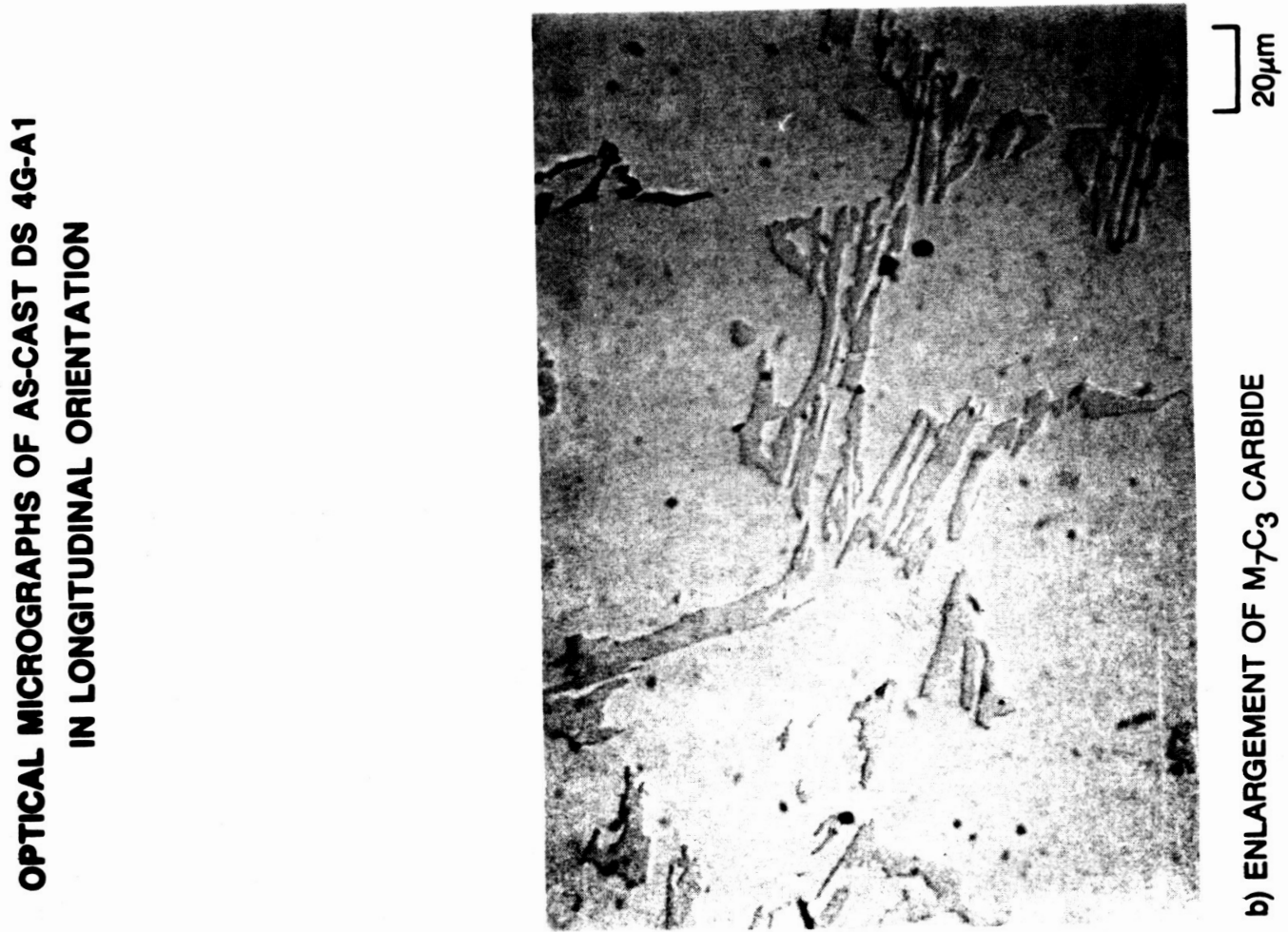

$87-3-22-1$ 
FIG. 24

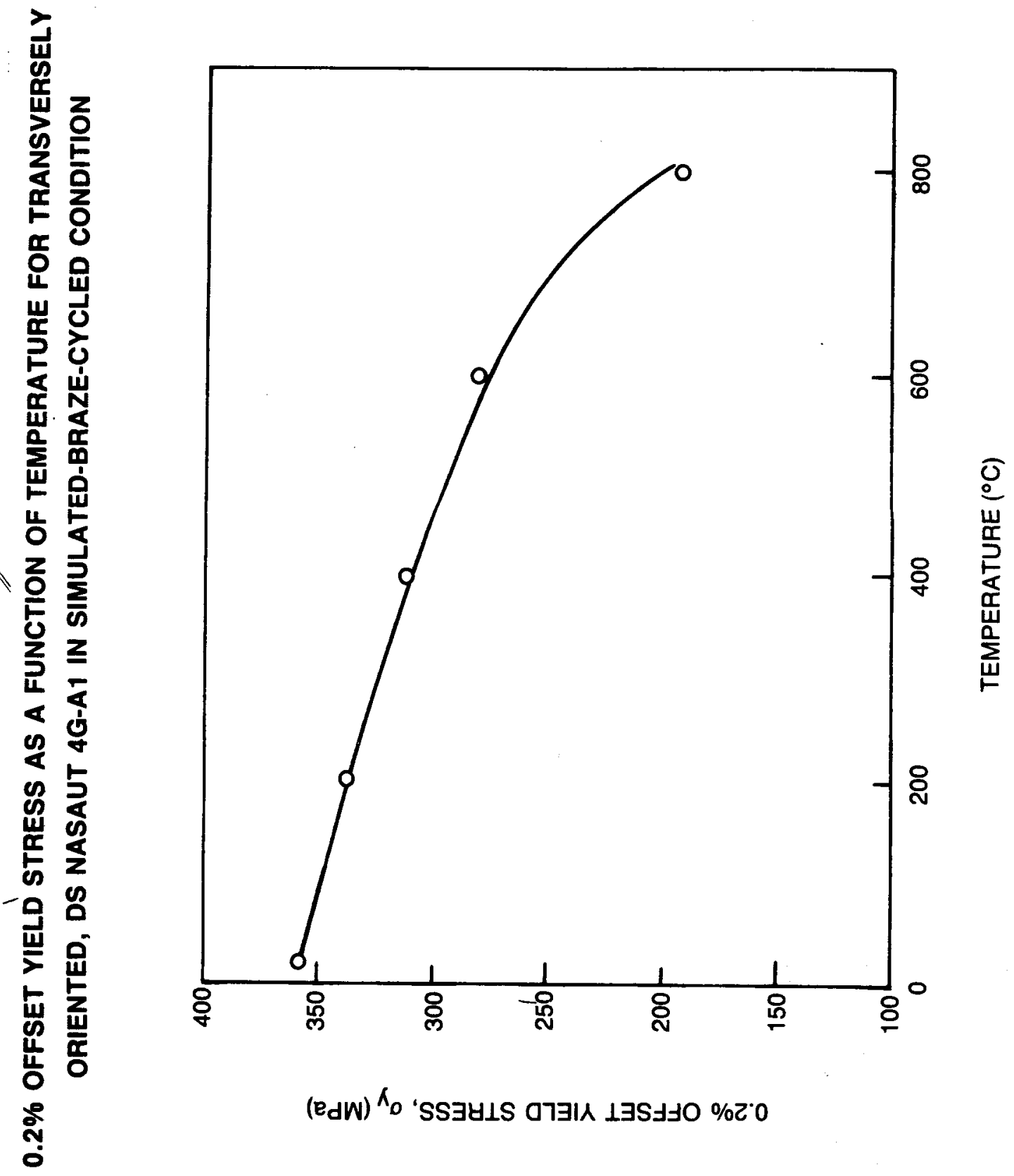



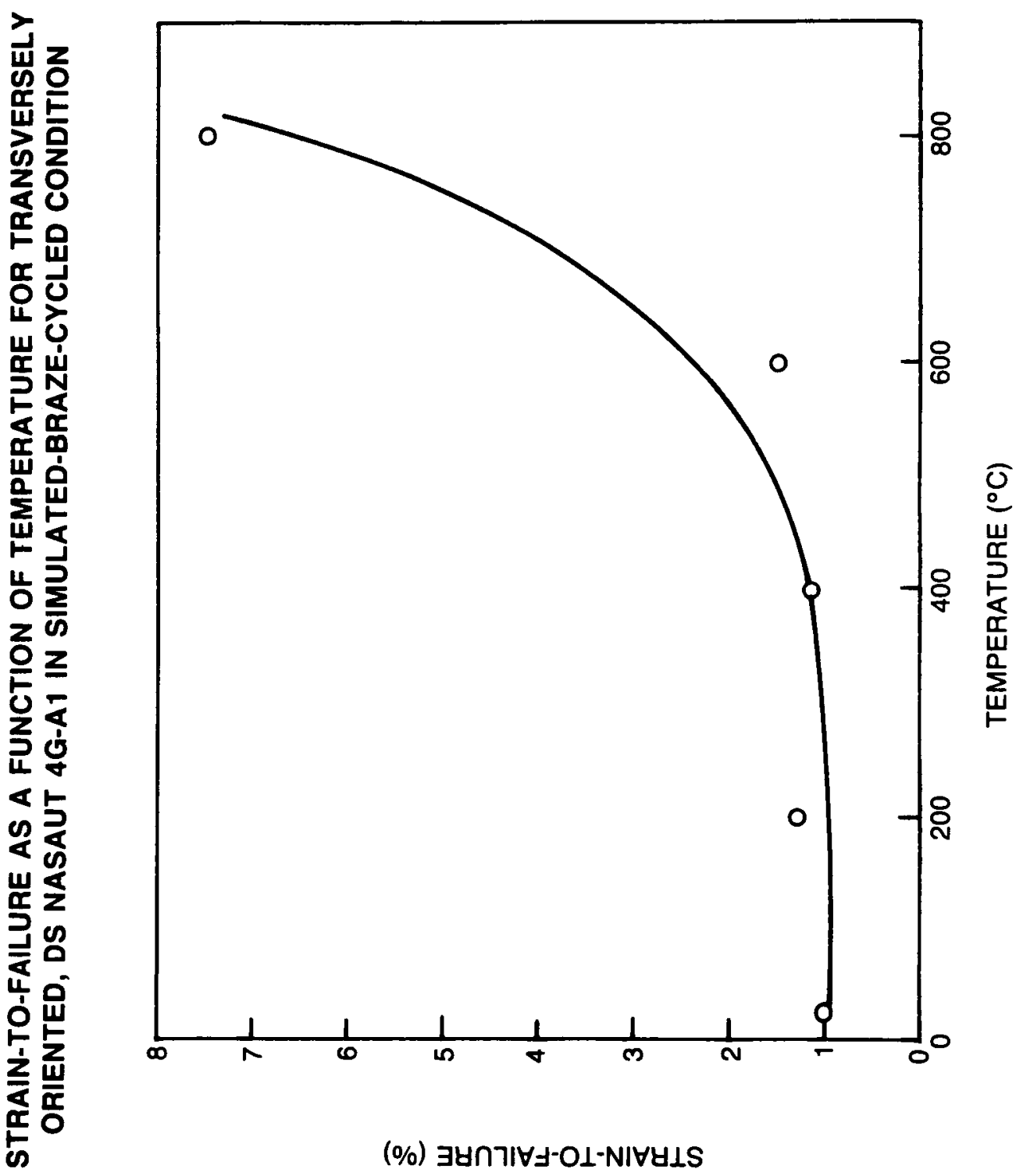


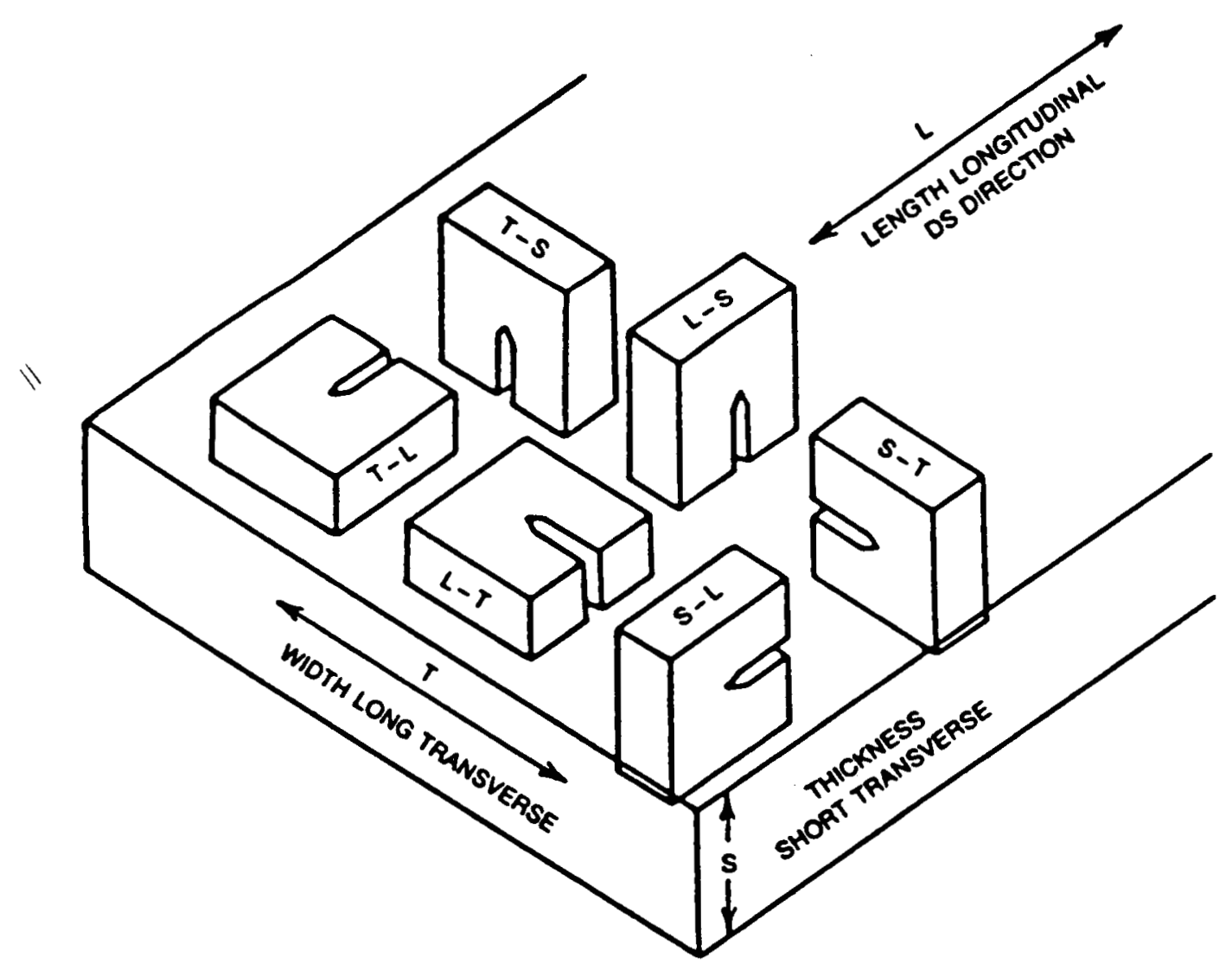




\section{LOW-MAGNIFICATION SEM FRACTOGRAPHS OF SIMULATED-BRAZE-CYCLED DS NASAUT 4G-A1 FRACTURE TOUGHNESS SPECIMENS}

a) TRANSVERSE (T-L) ORIENTATION

ORIGINAL PAGE

BLACK AND WHITE PHOTOGRAPH
ORIGINAL PAGE IS OF POOR QUALITY

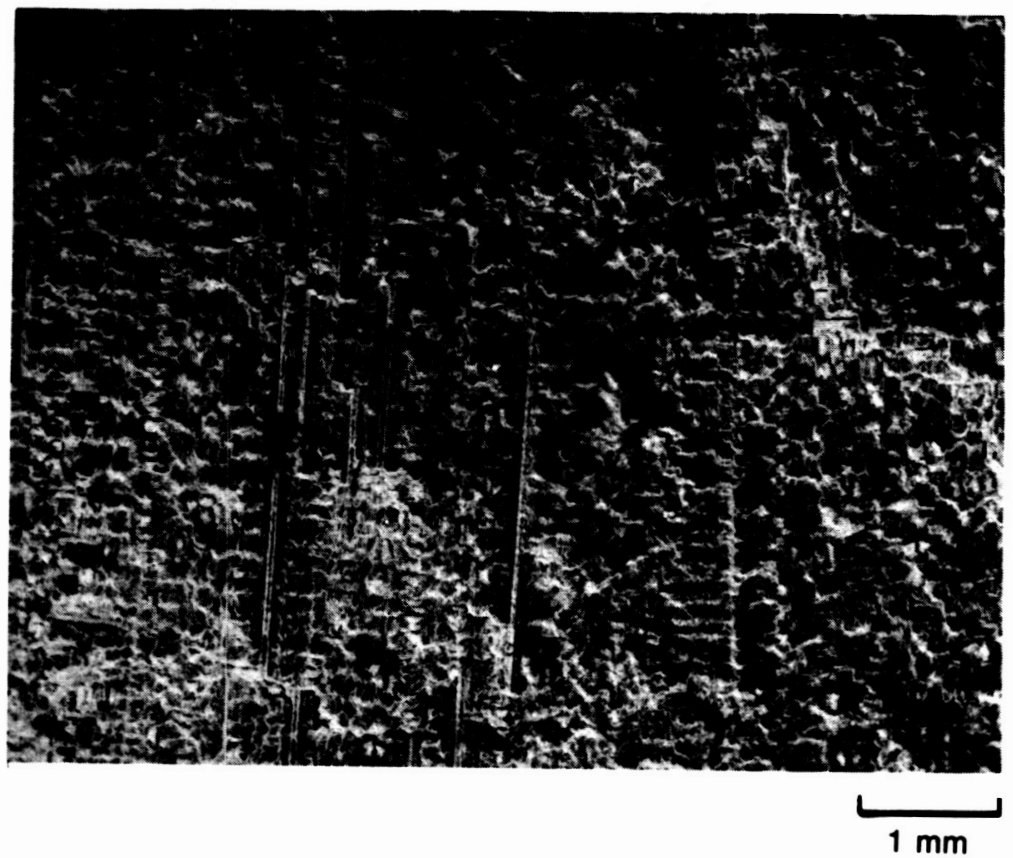

b) LONGITUDINAL (L-T) ORIENTATION

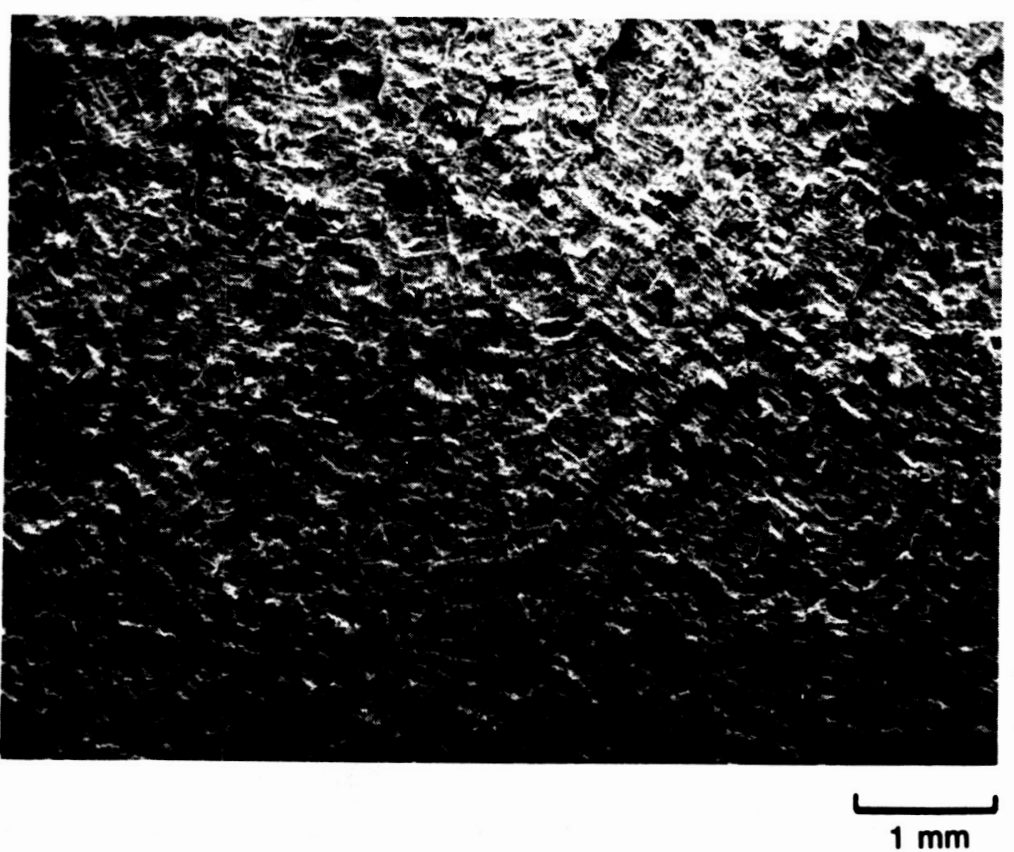




\section{HIGHER-MAGNIFICATION SEM FRACTOGRAPHS OF SIMULATED-BRAZE-CYCLED DS NASAUT 4G-A1 FRACTURE TOUGHNESS SPECIMENS}

a) TRANSVERSE (T-L) ORIENTATION

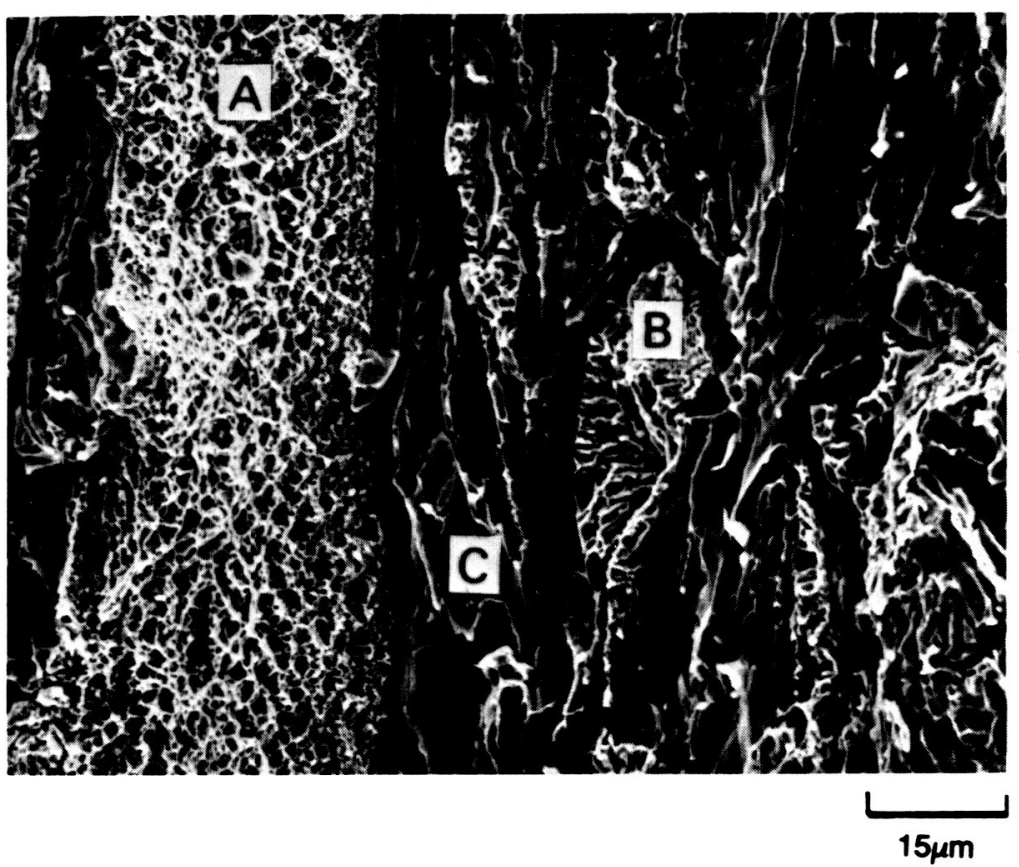

b) LONGITUDINAL (L-T) ORIENTATION

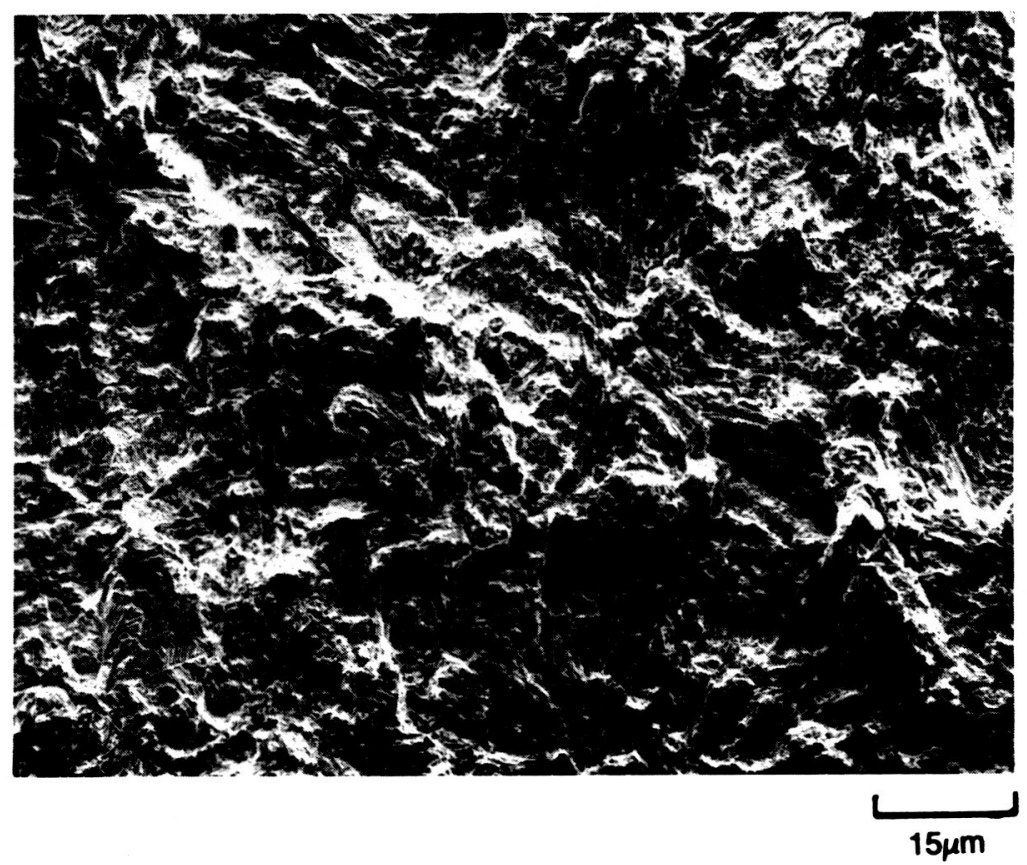

ORIGINAL PAGE

8L.ACK AND WHITE PHOTOGRAPH 
SCHEMATIC REPRESENTATION OF FRACTURE TOUGHNESS SPECIMEN AND RELATIONSHIP TO METALLOGRAPHIGALLY EXAMINED SURFACE

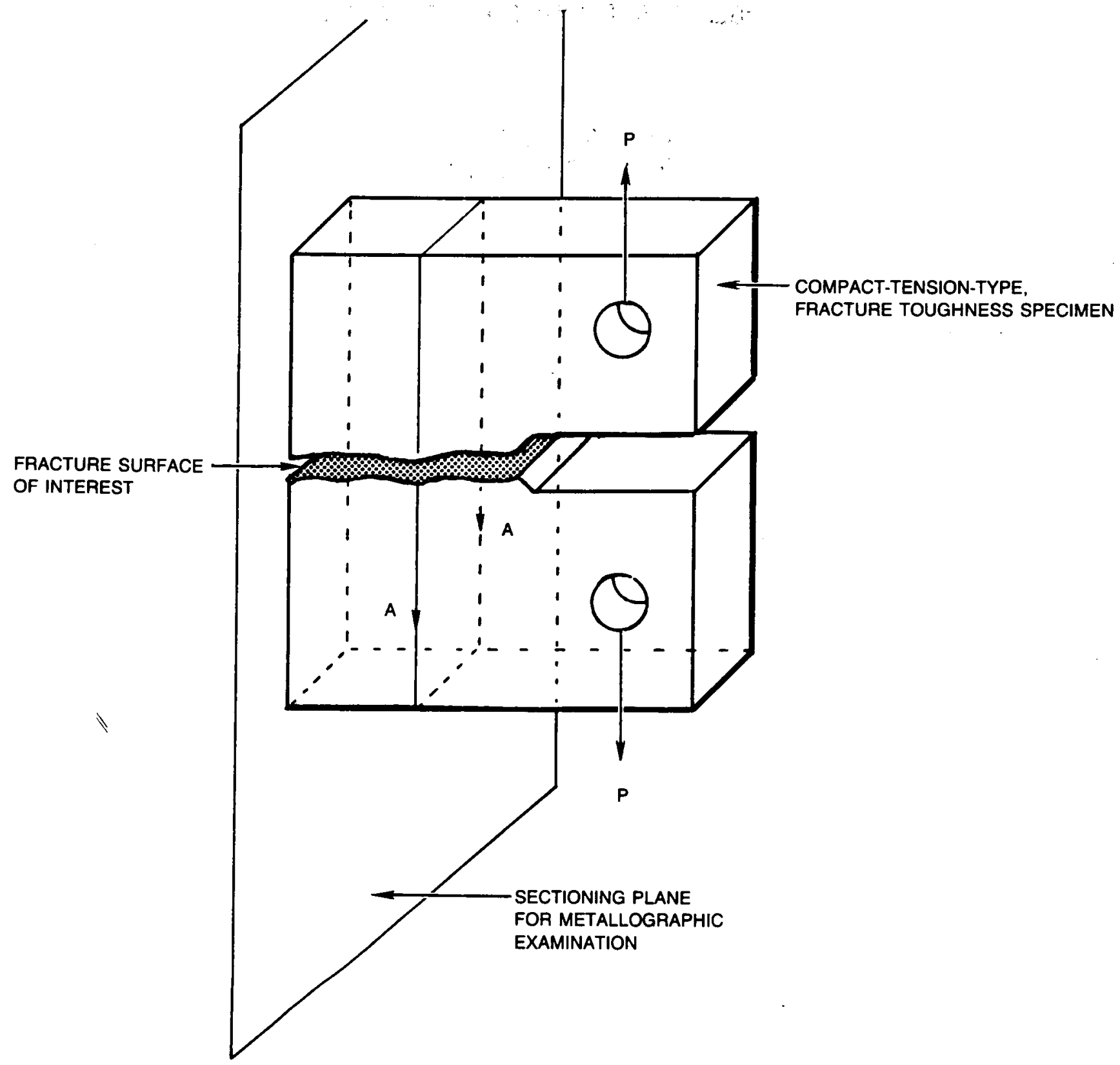

SECTION A-A

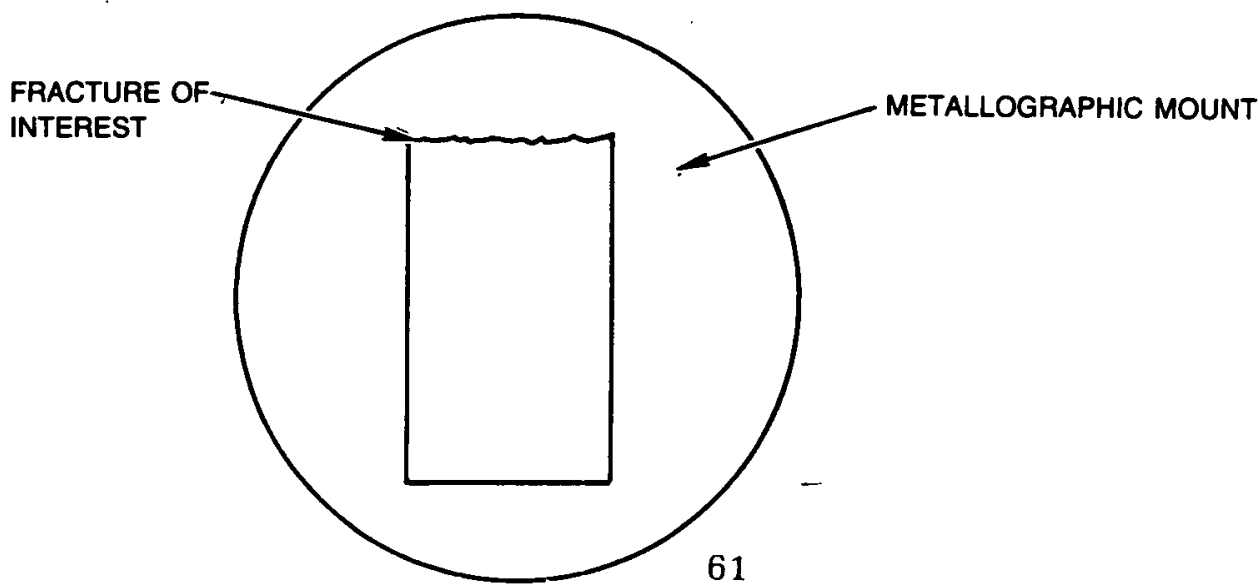


ORIGINAL PAGE IS

OF POOR QUALITY

OPTICAL MICRO-FRACTOGRAPH OF THE LONGITUDINAL (L-T) ORIENTATION FRACTURED AT ROOM TEMPERATURE

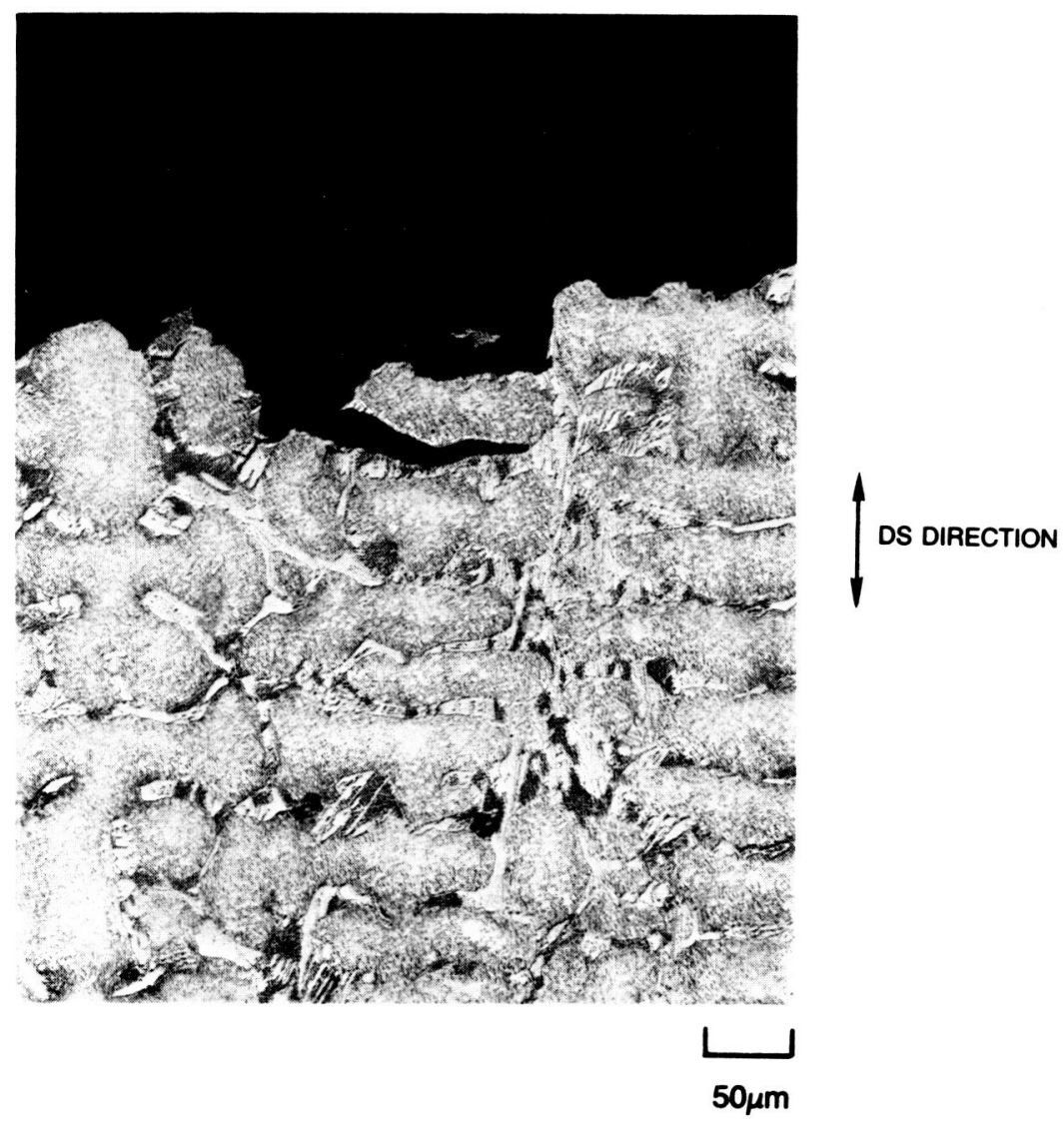




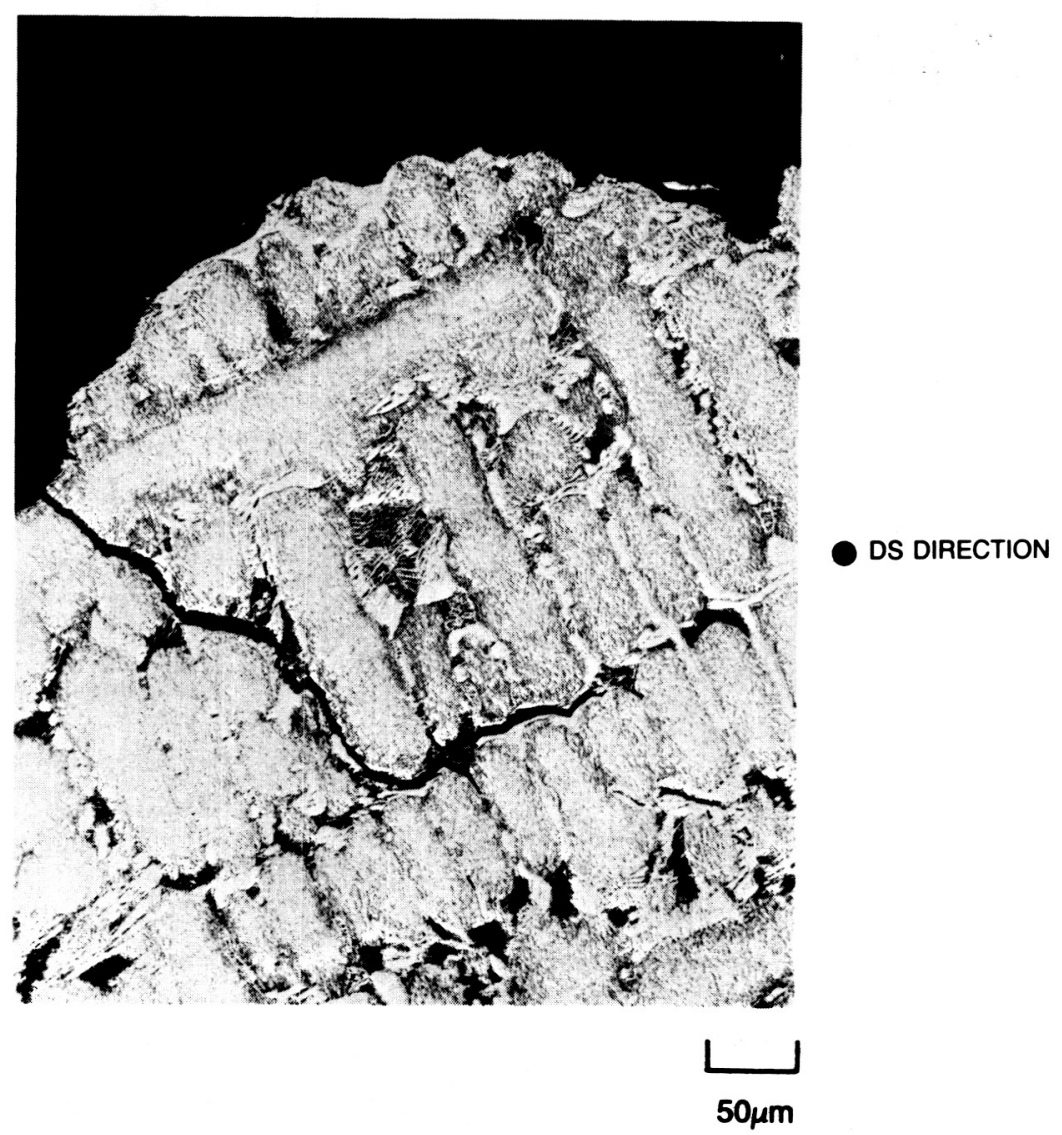

ORIGINAL PAGE

BLACK AND WHITE PHOTOGRAPH

ORIGINAL PAGE IS

OF POOR QUALITY

$87-10-12-3$ 


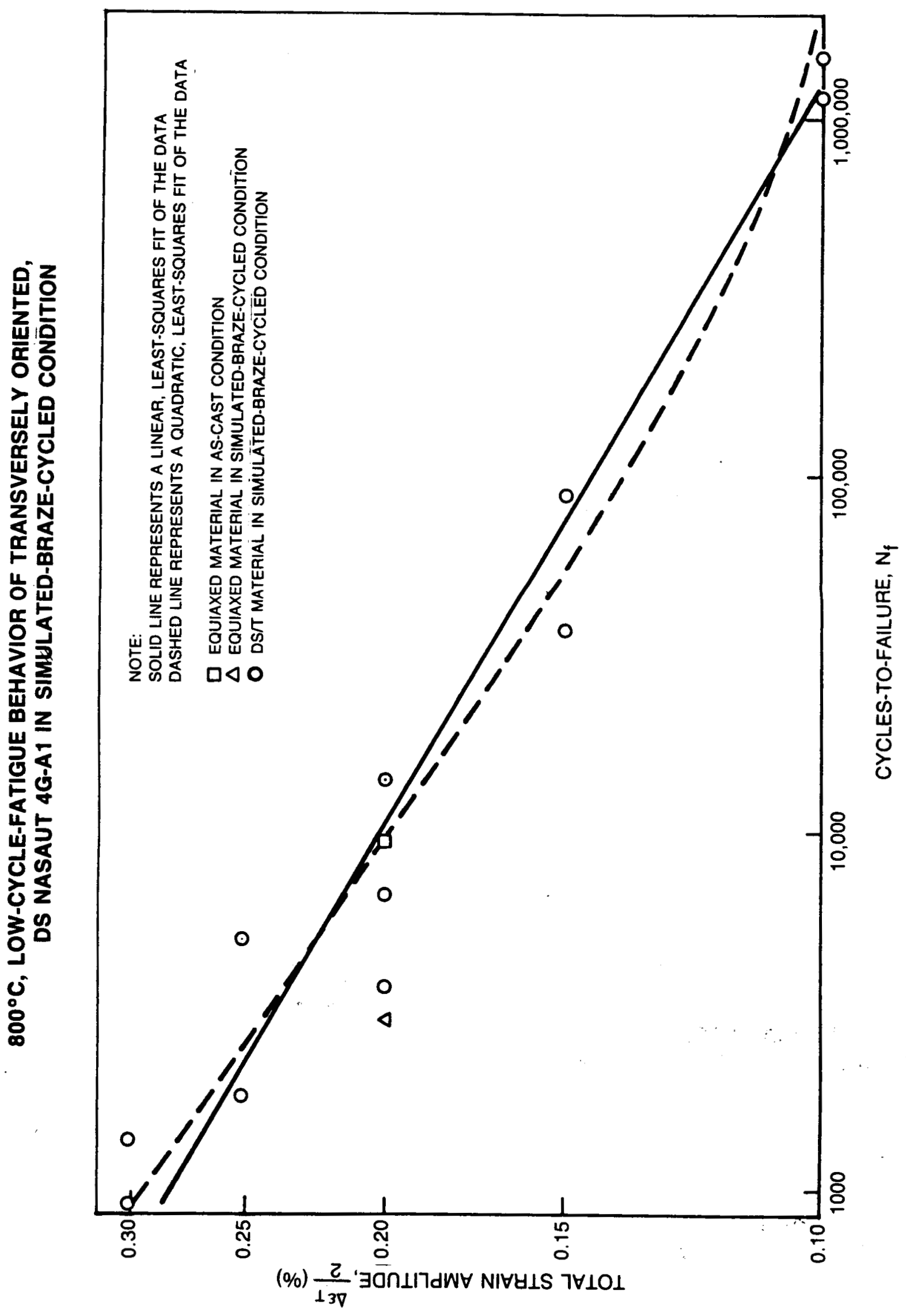




\section{HIGH-CYCLE FATIGUE OF VARIOUSLY HEAT-TREATED NASAUT 4G-A1 AT $22^{\circ} \mathrm{C}$}

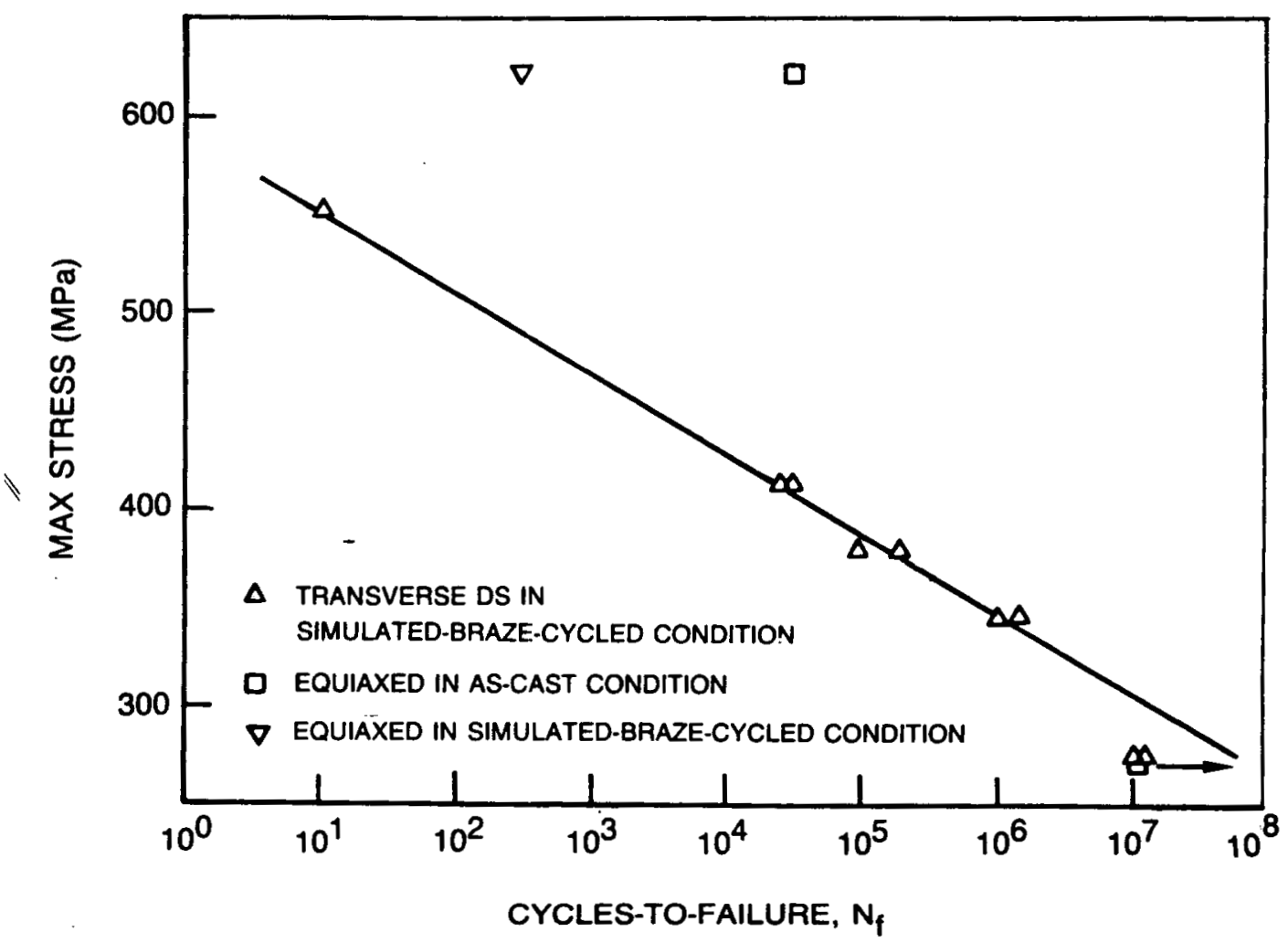


HIGH-CYCLE FATIGUE OF VARIOUSLY HEAT-TREATED NASAUT 4G-A1 AT $200^{\circ} \mathrm{C}$

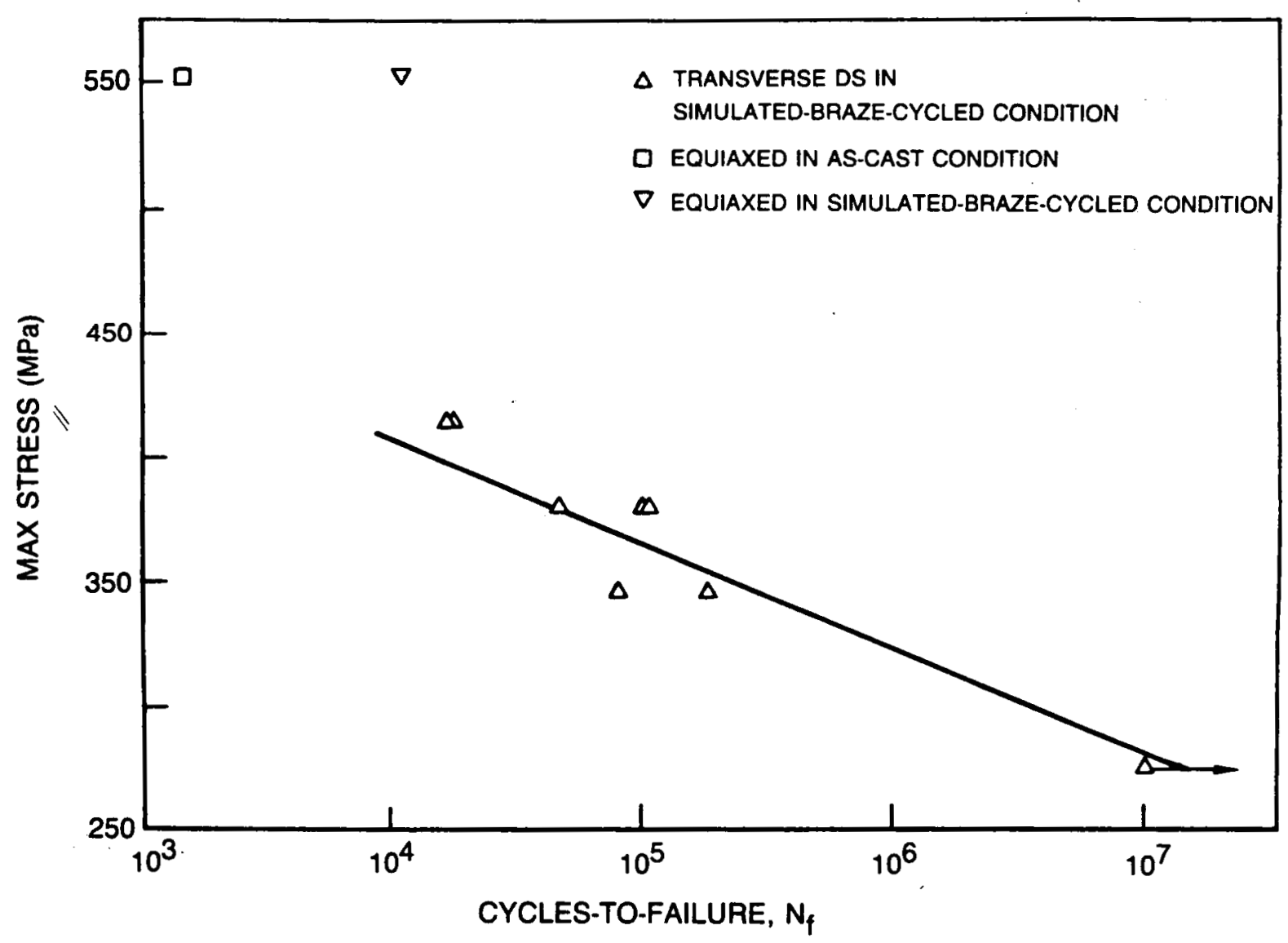




\section{HIGH-CYCLE FATIGUE OF VARIOUSLY HEAT-TREATED NASAUT 4G-A1 AT $400^{\circ} \mathrm{C}$}

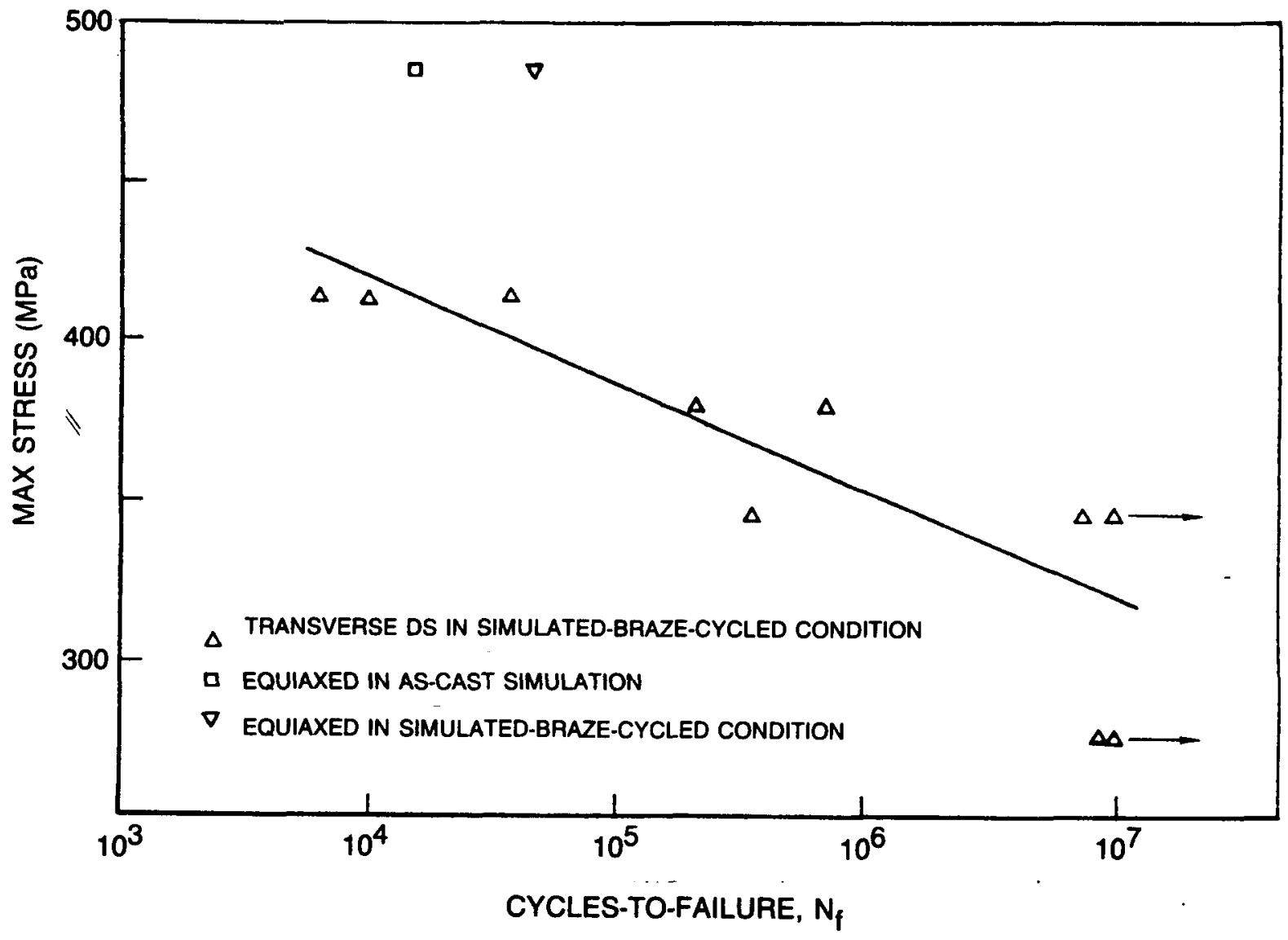




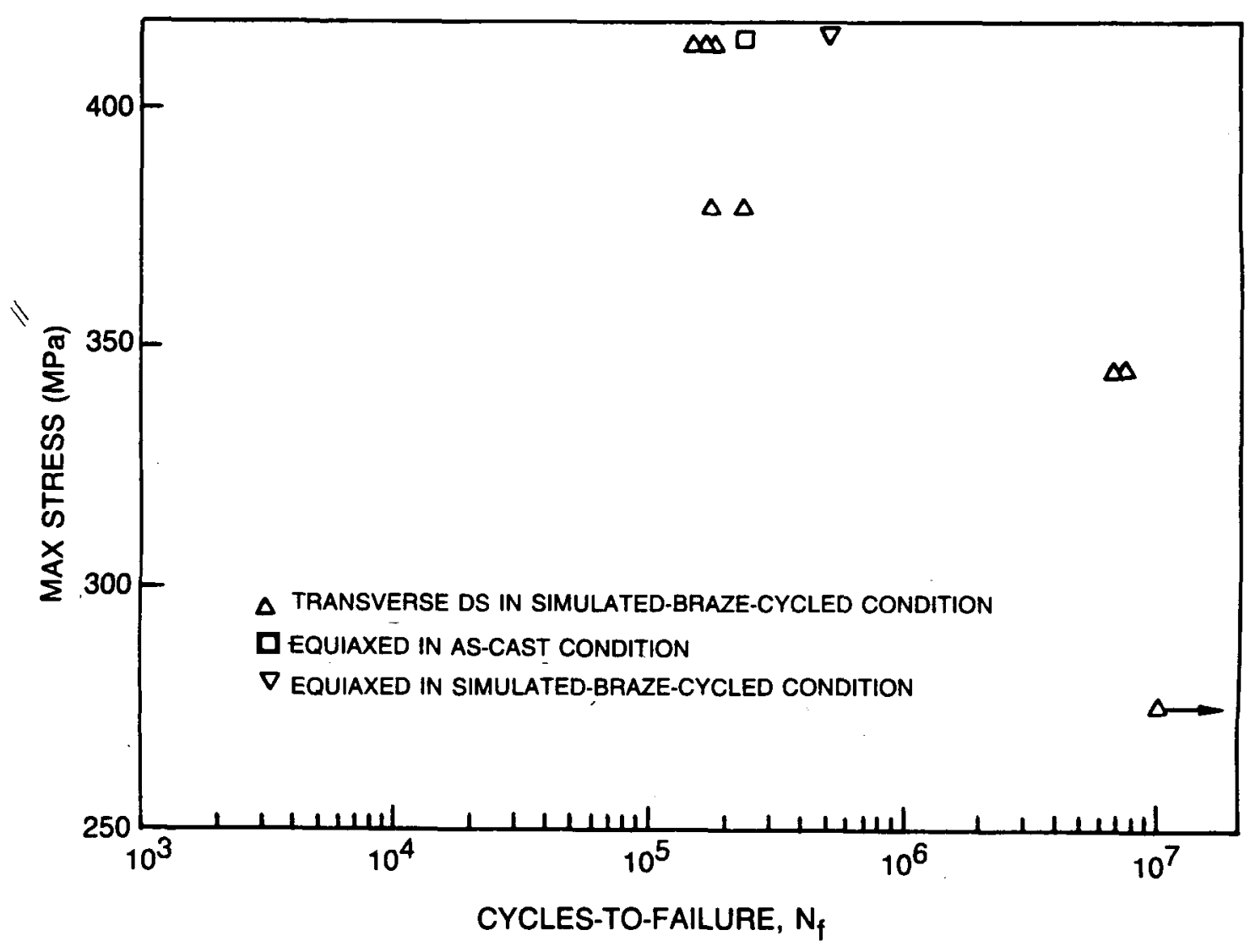




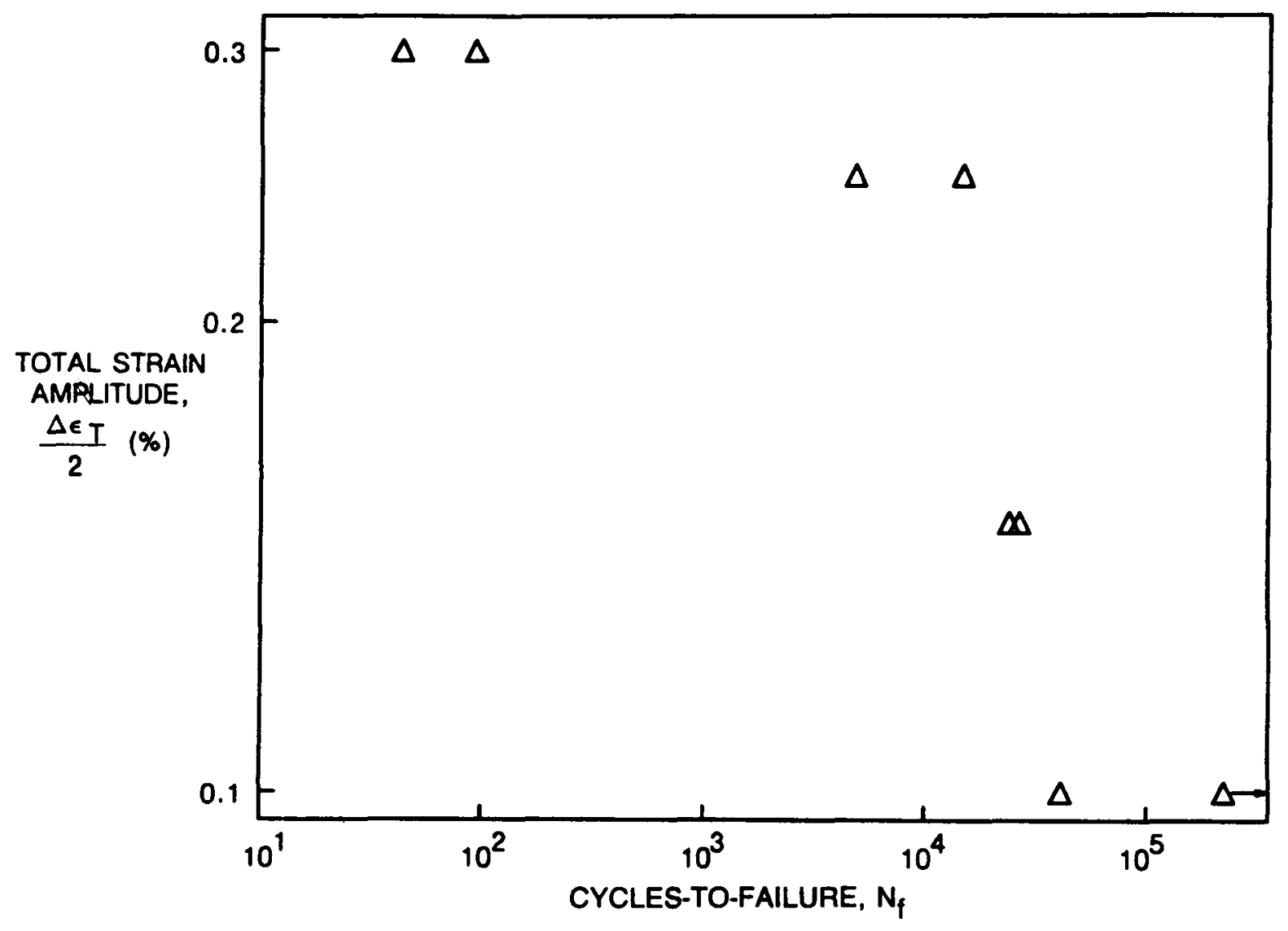




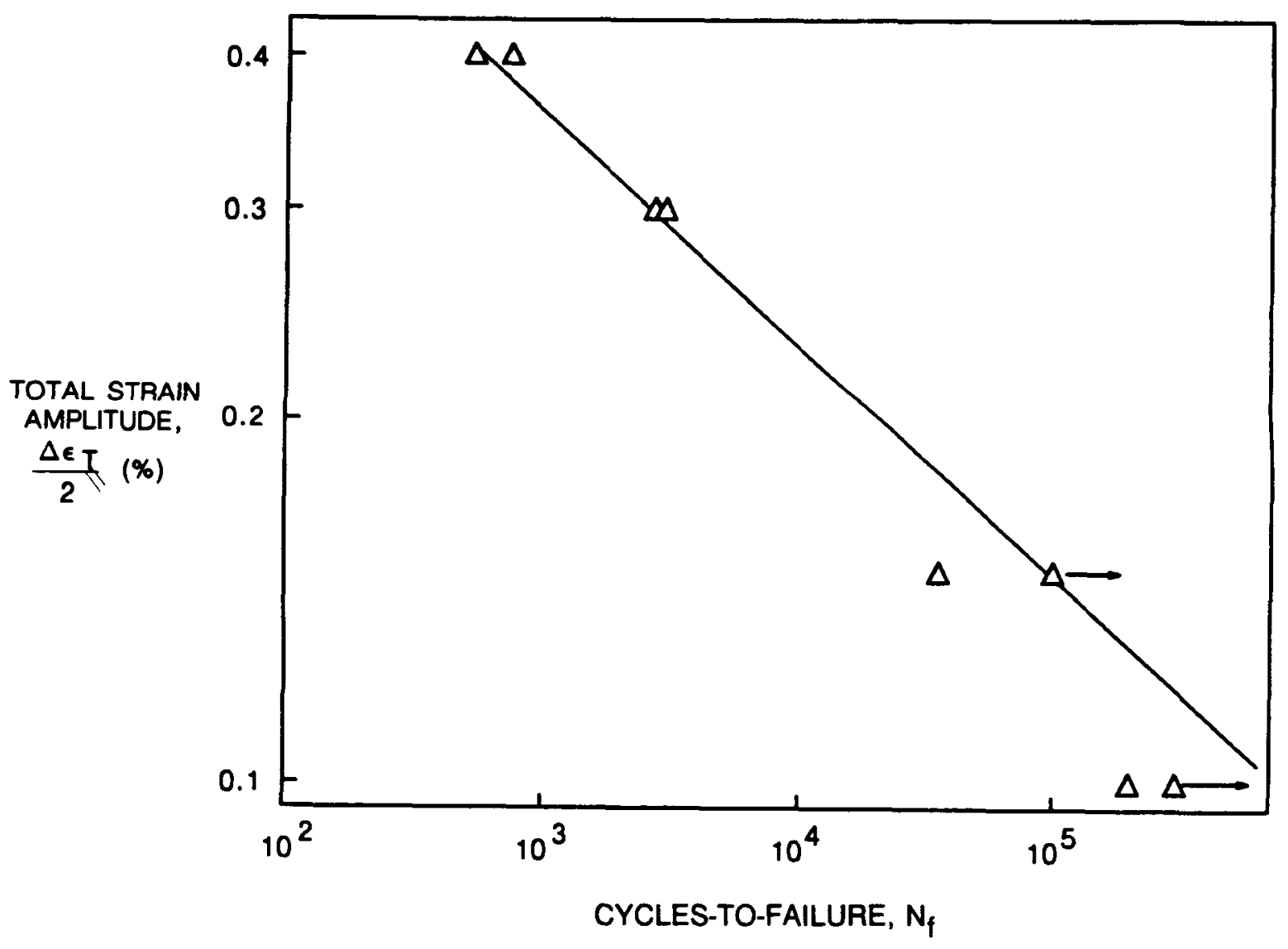




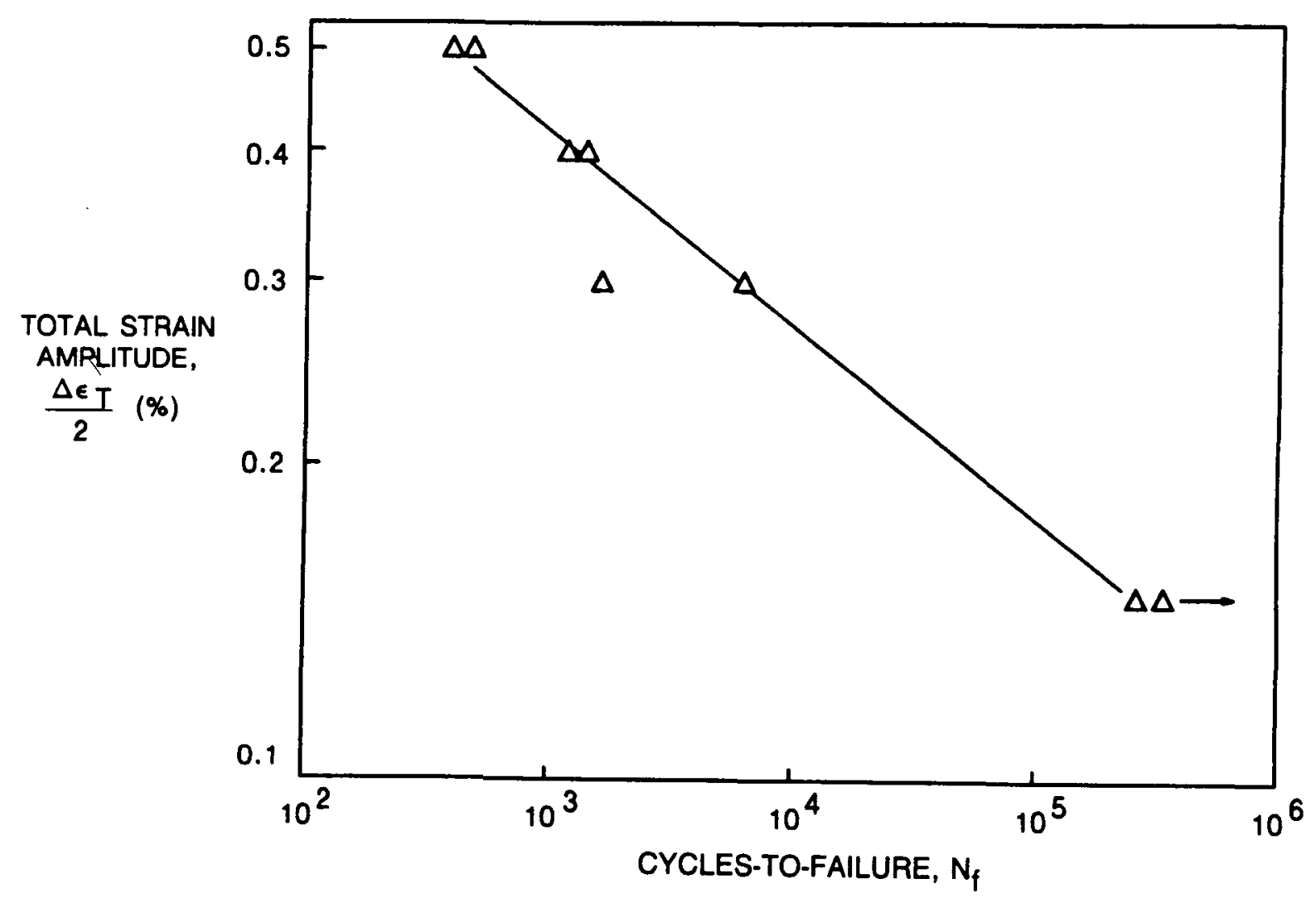




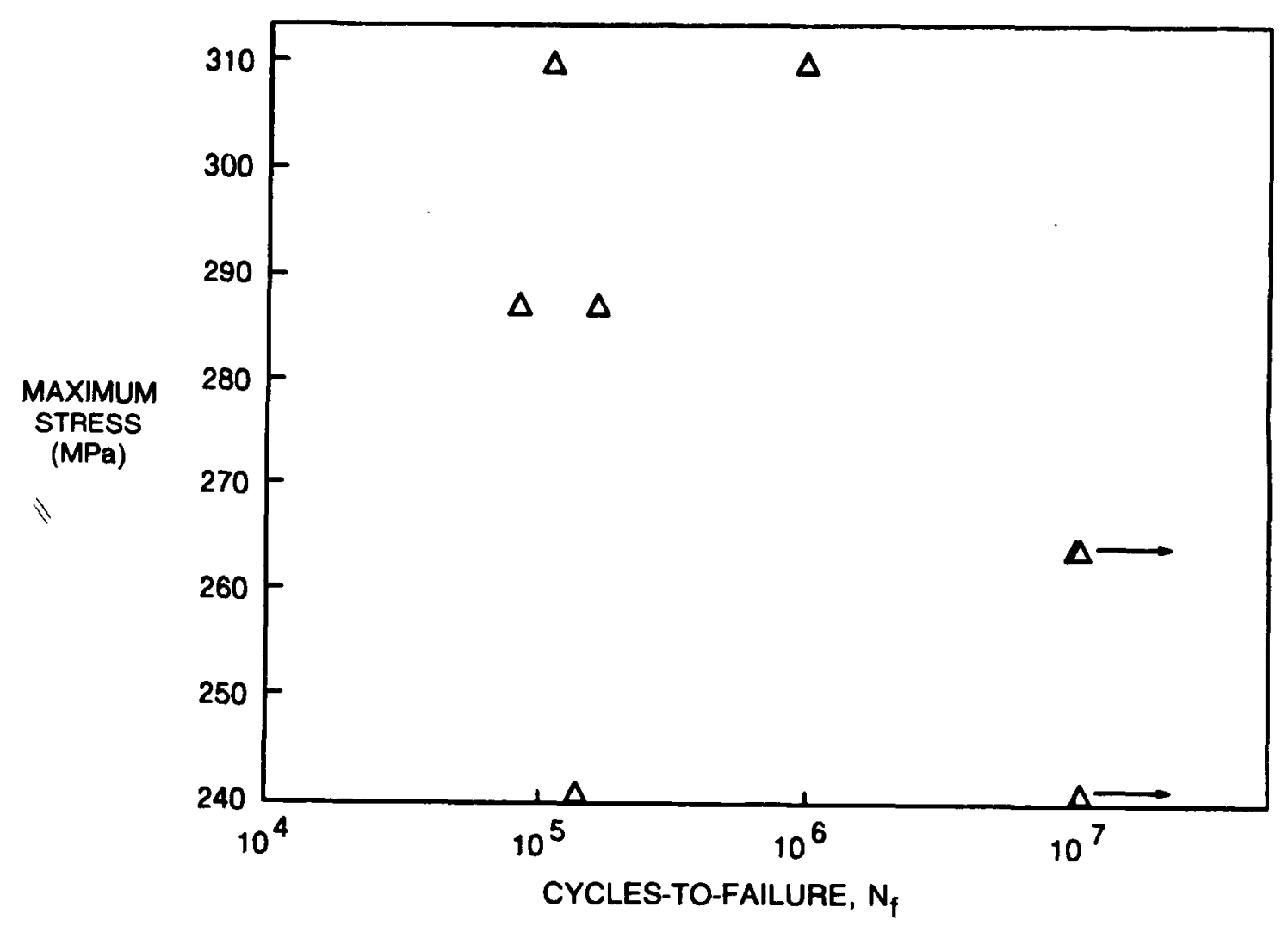




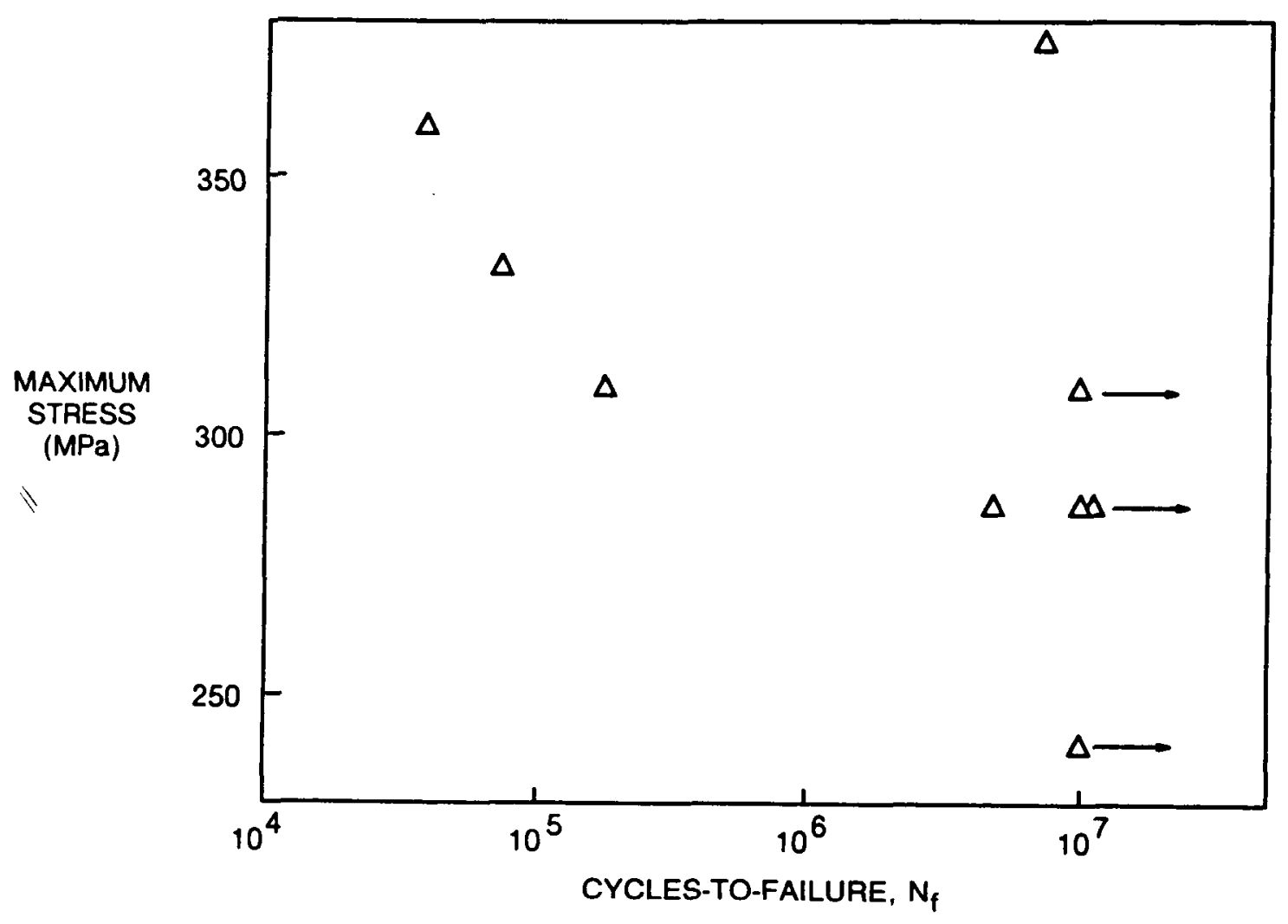


HIGH-CYCLE FATIGUE OF SIMULATED-BRAZE-CYCLED, DS/L NASAUT 4G-A1 AT $800^{\circ} \mathrm{C}$

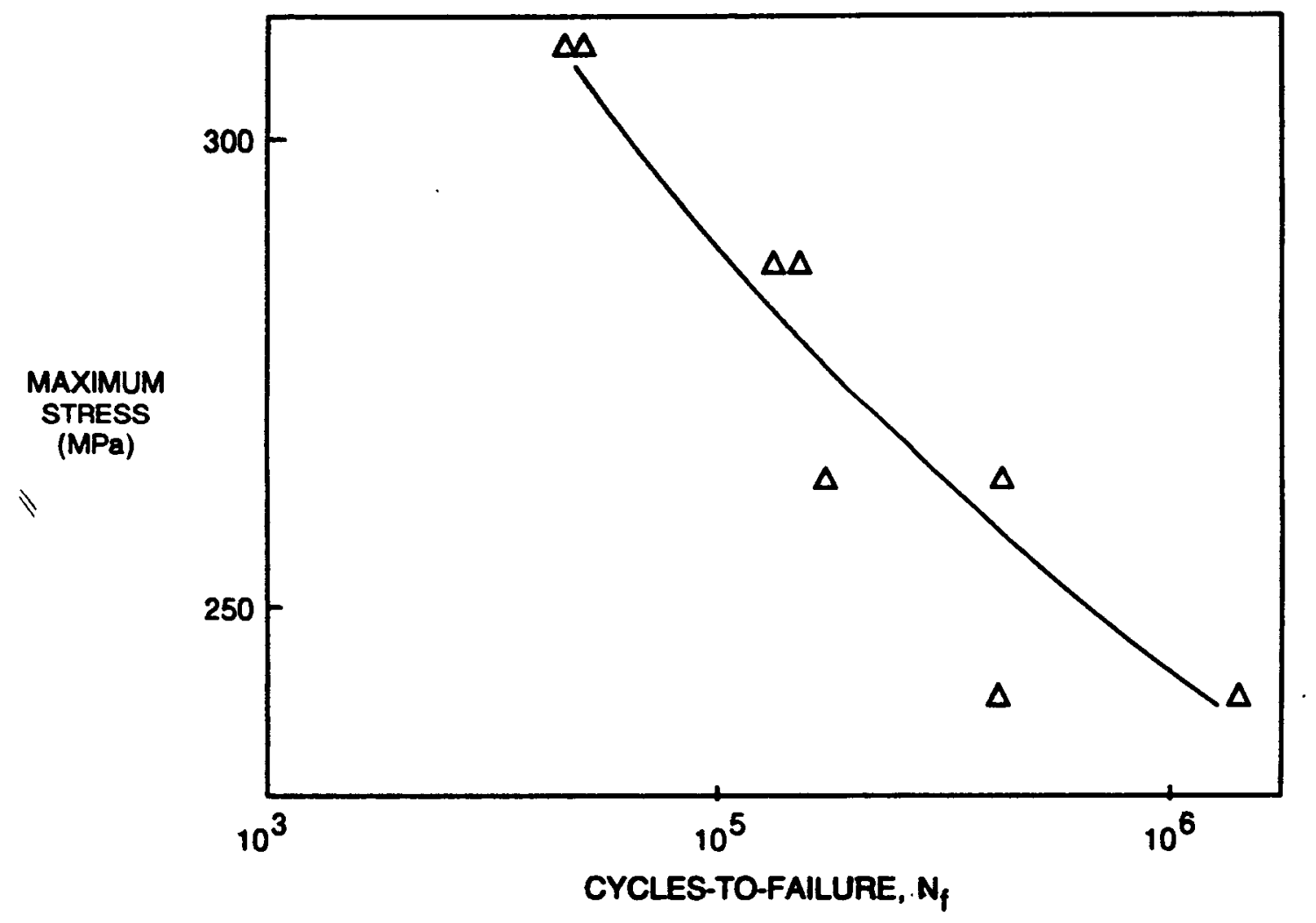

$89-3-50-6$ 


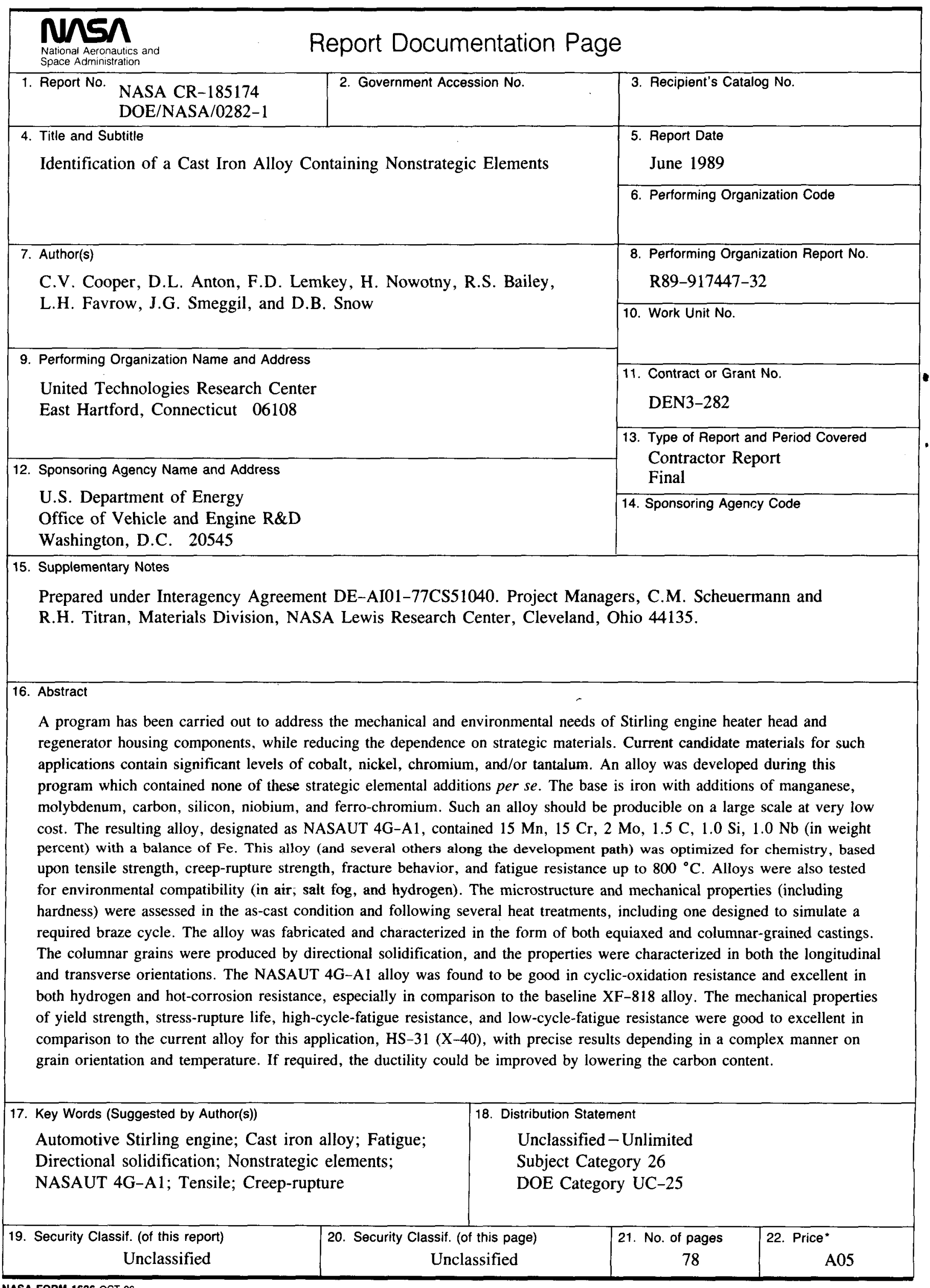

ASA CR-185174

2. Government Accession No.

OE/NASA/0282-1

1989

6. Performing Organization Code

Performing Organization Report No.

R89-917447-32

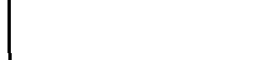

